\title{
Laser Ablation Inductively Coupled Plasma Mass Spectrometry U-Pb Dating of Detrital and Magmatic Zircons of Glacial Diamictites and Pebbles in Late Ordovician Sediments of the Taurides and Southeast Anatolian Autochthon Belt, Turkey: Indications for Their Arabian-Nubian Provenance
}

\author{
Semih Gürsu, ${ }^{1,2, \star}$ Andreas Möller, ${ }^{1}$ Doğan Usta, ${ }^{3}$ Serhat Köksal, ${ }^{4}$ Şerafettin Ateș, ${ }^{5}$ \\ Emmanuel D. Sunkari, ${ }^{2}$ and M. Cemal Göncüoğlu ${ }^{6}$ \\ 1. Isotope Geochemistry Laboratory, Department of Geology, University of Kansas, Lawrence, Kansas, USA; \\ 2. Muğla Sitkı Koçman University, Muğla, Turkey; 3. Adana Division, Mineral Research and Exploration \\ (MTA) General Directorate, Adana, Turkey; 4. Central Laboratory, Middle East Technical University, \\ Ankara, Turkey; 5. Department of Geological Research, MTA General Directorate, Ankara, Turkey; \\ 6. Department of Geological Engineering, Middle East Technical University, Ankara, Turkey
}

\begin{abstract}
A B S T R A C T
Late Ordovician (Hirnantian) glacio-marine deposits in the Central and Eastern Taurides and Southeast Anatolian Autochthon Belt (SAAB) in Turkey are mainly composed of diamictites, subrounded granitic pebbles, and rounded/ subrounded lonestone pebbles. The granitic pebbles are dated as $576.5 \pm 3.3,576.7 \pm 5.7,598.4 \pm 7.5,717.5 \pm 8.0,789.5 \pm$ 3.7, and $964.6 \pm$ 4.6 Ma. The geochemical signatures and dated granitic pebbles in the Central and Eastern Taurides are interpreted to have been derived from the Late Neoproterozoic granitoids/metagranitic rocks of the Arabian-Nubian Shield (ANS; the Sinai Peninsula and the Eastern Desert of Egypt). The youngest ${ }^{206} \mathrm{~Pb} /{ }^{238} \mathrm{U}$ ages in the diamictites $(499.1 \pm 4.2 \mathrm{Ma}$ in the SAAB, $530.5 \pm 5.3 \mathrm{Ma}$ in the Eastern Taurides, and 562.5 $\pm 5.4 \mathrm{Ma}$ in the Central Taurides) and in the lonestones (528.2 $\pm 4.5 \mathrm{Ma}$ in the Central Taurides, $530.8 \pm 5.2 \mathrm{Ma}$ in the Eastern Taurides) indicate that detrital zircons were directly transported mainly from the northern margin of Gondwana and/or Arabia during the Late Ordovician, not from peri-Gondwanan parts of the European margin. Kernel/probability density diagrams of zircon ages from the lonestone pebbles in the Eastern and Central Taurides are interpreted as evidence for their derivation from Late/Middle Cambrian siliciclastic rocks in the Israeli part of the Sinai Peninsula. The provenance of detrital zircon populations in the diamictites in the Central and Eastern Taurides is directly correlated with magmatic activity of the Elat (Taba)-Feiran island arc, the Sa'al island arc, and the postcollisional magmatic suites in the Sinai Peninsula (Egypt). However, the corresponding successions in the SAAB have more abundant Late Cryogenian age components, suggesting the Ha'il/Afif/Ad Dawadimi/Ar-Rayn terranes of the eastern Arabian Shield as their provenance. These distinctive age patterns indicate that glacio-marine successions in the SAAB had different paleogeographic positions than their equivalent units in the Central and Eastern Taurides during deposition of the Late Ordovician glacio-marine units.
\end{abstract}

Online enhancements: appendix, tables, figures.

\section{Introduction}

Late Ordovician (Hirnantian) proximal glaciomarine deposits at the northern margin of Gond-

Manuscript received March 30, 2016; accepted October 25, 2016; electronically published February 1, 2017.

* Author for correspondence; e-mail: semihgursu@mu.edu.tr. wana (Africa and Arabia) and their distal parts in the southern margin of the European continent are one of the most extensive glacio-marine deposits in the world despite the short duration of the glacial episode (shorter than 1 m.yr.; e.g., Ghienne 2003; fig. 1).

The products of the short-lived but intense Late Ordovician glacial event in Gondwana are best exposed

[The Journal of Geology, 2017, volume 125, p. 165-202] (C) 2017 by The University of Chicago. All rights reserved. 0022-1376/2017/12502-0005\$15.00. DOI: 10.1086/690199 


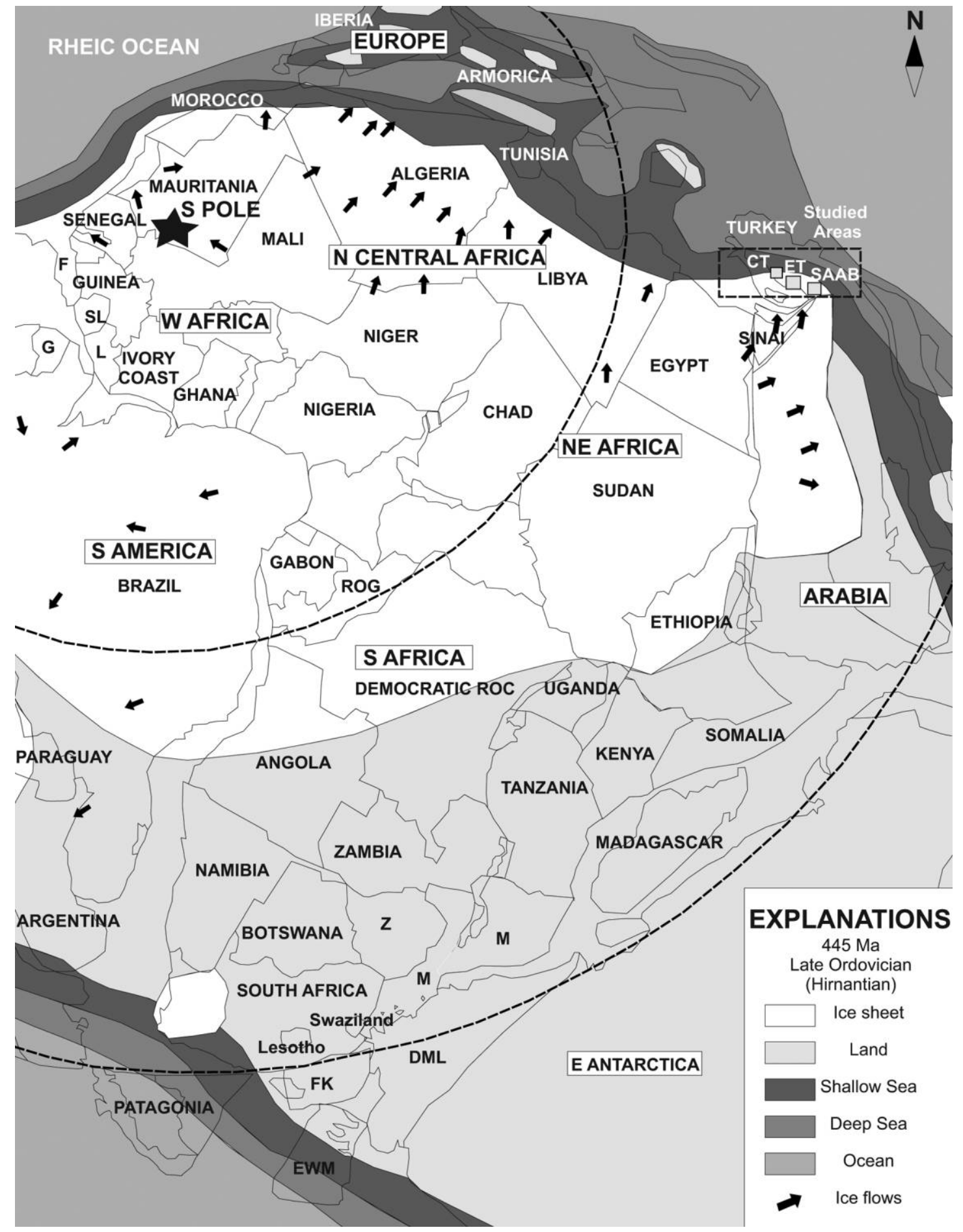

Figure 1. Paleogeographic reconstruction of central Gondwana during the Late Ordovician (Hirnantian), indicating glacial and periglacial distributions at $445 \mathrm{Ma}$. DML = Dronning Maud Land; CT = Central Taurides; ET = Eastern Taurides; EWM = Ellsworth-Whitmore Mountains; F = Florida; FK = Falklands; $\mathrm{G}=$ Guyana; $\mathrm{L}=\mathrm{Liberia}$; $\mathrm{M}=$ Mozambique; SL = Sierra Leone; SAAB = South Anatolian Autochthon Belt; $\mathrm{Z}=$ Zimbabwe. From Torsvik and Cocks (2011). 
in north-central Africa (Morocco [Destombes et al. 1985; Le Heron 2007; Le Heron and Craig 2008], Algeria and Nigeria [Beuf et al. 1971; Biju-Duval et al. 1981; Linnemann et al. 2011; Avigad 2012], Libya [Massa 1988; Ghienne et al. 2003; Le Heron and Craig 2008; Le Heron et al. 2010], Niger [Denis et al. 2006]), western Africa (Mauritania [Deynoux et al. 1985; Willefert 1988; Ghienne and Deynoux 1998], Sierra Leone [Tucker and Reid 1973]), South Africa (Lesotho, Swaziland [Hiller 1992]), Arabia (Oman [Martin et al. 2008], Jordan [Abed et al. 1993; Turner et al. 2005], Saudi Arabia [Vaslet 1990; McGillivray and Husseini 1992; Paris et al. 2000; Clark-Lowes 2005], Iran [Ghavidel-syooki et al. 2011]), South America (Brazil, Argentina [Caputo 1988; Martinez 1998; Astini 2003]), and Europe (Spain [Fortuin 1984; Gutiérrez-Marco et al. 2010], Germany [Rösel et al. 2014], France [Robardet and Dore 1988], Czech Republic [Śtorch 2006], Italy [Avigad 2012], Turkey [Monod et al. 2003; Ghienne et al. 2010]; fig. 1). The distal parts of the Late Ordovician glacio-marine successions in the northern and northeastern margin of Arabia are best exposed in the Central Taurides (CT) and the Eastern Taurides (ET) of the Tauride-
Anatolide Platform (TAP) and the Southeast Anatolian Autochthon Belt (SAAB) in southern Turkey (e.g., Cater and Tunbridge 1992; Bozdoğan et al. 1996; Göncüoğlu 1997; Göncüoğlu and Kozlu 2000; Ghienne et al. 2010; Özgül and Kozlu 2002; Monod et al. 2003; Göncüoğlu et al. 2004; Paris et al. 2007).

Previous studies (e.g., Monod et al. 2003; Ghienne et al. 2010) have shown that Late Ordovician successions, especially in the Taurides, contain unique fragments of granitic pebbles as dropstones and lonestones, located especially in the FekeSaimbeyli-Tufanbeyli (Adana) and Silifke (Ovacık) areas, respectively (fig. 2). The petrogenetic and geochronological characteristics of the rock fragments transported during glacial episodes can give important evidence to determine the provenance of the glacio-marine deposits. Detrital and magmatic zircon geochronology is the most important tool to determine the provenance of the diamictites deposited in either the distal or the proximal sedimentary environments. The individual coarsegrained pebbles within finer-grained sediments in the ice-rafted debris derived from the glacial processes are named dropstone or lonestone (Gornitz

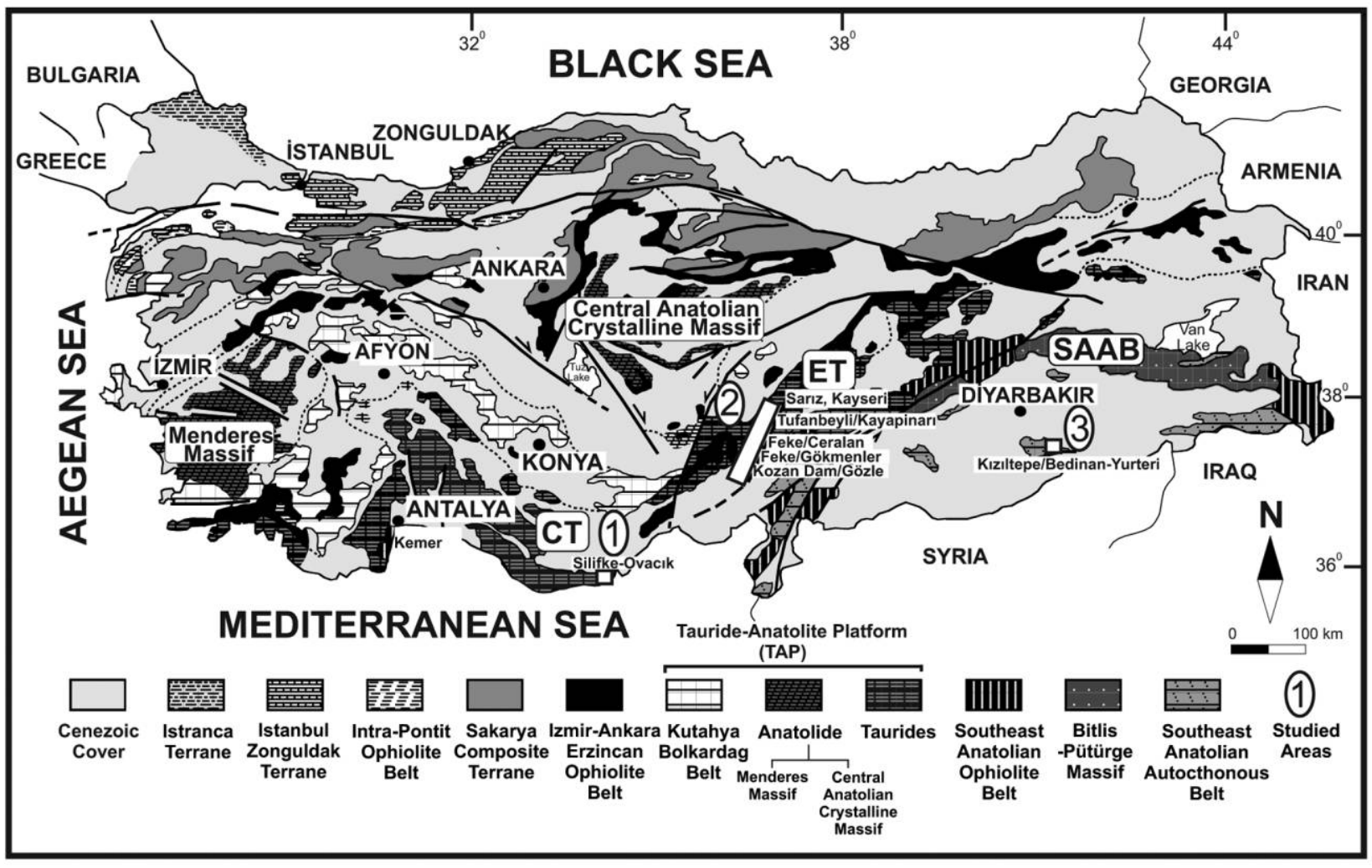

Figure 2. Structural map of the main tectonic units of Turkey, showing the glacial successions in the Central Taurides $(\mathrm{CT} ; 1)$, the Eastern Taurides $(\mathrm{ET} ; 2)$, and the Southeast Anatolian Autochthon Belt $(\mathrm{SAAB} ; 3)$. Modified from Göncüoğlu (2010). A color version of this figure is available online. 
2009). The term "dropstone" refers to the ice-rafted lithic particles of the granitic pebbles in this study, and the term "lonestone" denotes the ice-rafted lithic particles of the sedimentary pebbles. The provenance of the Late Ordovician (Hirnantian) glacial deposits in the TAP and the SAAB are speculative to date. The aim of this study is to determine the provenance of the Late Ordovician (Hirnantian) glacio-marine successions cropped out in the CT (Silifke-Ovac1k), the ET (Tufanbeyli/Kayapinari, Feke/Ceralan, Feke/Gökmenler, Kozan Dam/Gözle), and the SAAB (Kızıltepe/ Bedian-Kizlltepe/Bedian-Yurteri) by the laser ablation inductively coupled plasma mass spectrometry (LAICP-MS) U-Pb dating method on the magmatic zircons from dropstones and the detrital zircons from lonestones and diamictites. The results will be geochemically and geochronologically correlated with equivalent Pan-African autochthonous units in North Africa (Morocco, Algeria, Libya, Egypt) and Arabia (Saudi Arabia, Jordan, Israel).

\section{Geological Setting}

Previously, the Late Ordovician units in the TAP were named the Halityaylas1-Egripinar Formation by Özgül et al. (1973). These outcrops were studied in detail later by Kozlu et al. (2002), Monod et al. (2003), Paris et al. (2007), and Ghienne et al. (2010) and were renamed the Halevikdere Formation. Late Ordovician (Hirnantian) glacio-marine deposits mainly crop out in the areas of Bedinan-Yurtyeri-Kizıltepe (SAAB), Sariz-Kayseri (ET), Tufanbeyli-Adana (ET), FekeSaimbeyli-Adana (ET), Kozan-Adana (ET), and SilifkeOvacik (CT; fig. 2).

Outcrops of the Late Ordovician units in the SAAB (Bedinan-Yurteri-Kızlltepe) were previously evaluated as upper members of the Bedinan Formation by Dean et al. (1981). However, recent studies have shown that the Bedinan Formation is mainly composed of shale-dominated siliciclastic rocks and tempestite-type sandstones and is unconformably overlain by the Late Ordovician (Hirnantian) Halevikdere Formation (e.g., Monod et al. 2003; Ghienne et al. 2010). The Helevikdere Formation begins in this location with sandy diamictites, massive coarse-grained conglomeratic sandstones, and claybearing sandstones and continues upward with clayey sandstone-siltstone/mudstone alternations (fig. 3). Cretaceous carbonates are unconformably overlying the Ordovician successions in the SAAB (details in Monod et al. 2003; Ghienne et al. 2010). Similar Late Ordovician glacio-marine units in the ET mainly crop out at nine different locations (details in Özgül et al. 1973; Göncüoğlu and Kozlu 2000; Monod et al. 2003; fig. 2). The succession in general starts with the Early Ordovician (Tremadocian-Floian) Seydisehir Formation and is unconformably overlain by shallow marine siliciclastic deposits of the Upper Ordovician (Upper Katian) Sort Tepe Formation. The succession is conformably overlain by the Late Ordovician Halevikdere Formation in the ET (Monod et al. 2003; Kozlu and Ghienne 2012).

In the ET, the Halevikdere Formation begins with coarse-grained conglomeratic sandstones and pebblebearing sandstones with sandy diamictites, which belong to the lower glacial cycle (Ghienne et al. 2010). It continues with bedded sandy diamictites, coarsegrained laminated sandstones, sandstone lenses, pebblebearing sandstone (dropstones), and distal shallow marine fine-grained sandstone lenses and sandy/ muddy diamictites of the upper glacial cycle successions (Ghienne et al. 2010; fig. 3). The lower glacial cycle represents the glacial activities during the Early Hirnantian, and the upper glacial cycle connotes glaciation during the Late Hirnantian. Ice recessions occurred during both cycles, caused by a major transgressive interval coeval with a deglaciation event at the time (details in Ghienne et al. 2007).

Late Ordovician glacio-marine units in the CT crop out in the Silifke-Ovacık, Akyaka-Anamur, and Kemer (Antalya) areas (e.g., Demirtaşl1 1984; Monod et al. 2003; Ghienne et al. 2010; fig. 2). The succession in the Akyaka-Anamur starts with the Early Ordovician Seydişehir Formation, unconformably overlain by the Late Ordovician (Katian?) Bedinan Formation, and continues with the Late Ordovician Helevikdere Formation (Demirtaşlı 1984; Kozlu et al. 2002; Monod et al. 2003). A similar succession is observed in the Silifke-Ovacik area in the CT (Demirtaşlı 1984; Monod et al. 2003). Late Ordovician glacio-marine successions are also observed in different tectonic units in the Kemer (Antalya) area, which unconformably overlie the Late Ordovician (Katian) Sarıyardere Formation (Ghienne et al. 2010).

To determine their provenance, representative samples from the matrix of the diamictites, granitic pebbles (dropstones), and lonestones (sedimentary pebbles) were collected from studied successions from the TAP to the SAAB, which are presented in figure 3. Details on the geological features of the studied areas are given in section 1 of the appendix (available online).

\section{Methodology}

About 7-12 pounds of diamictite samples were used for the geochronological studies. The quartzite pebbles (sample DPK65 from the CT; sample DPK38A from the ET) were larger $(>10 \times 20 \mathrm{~cm})$ 


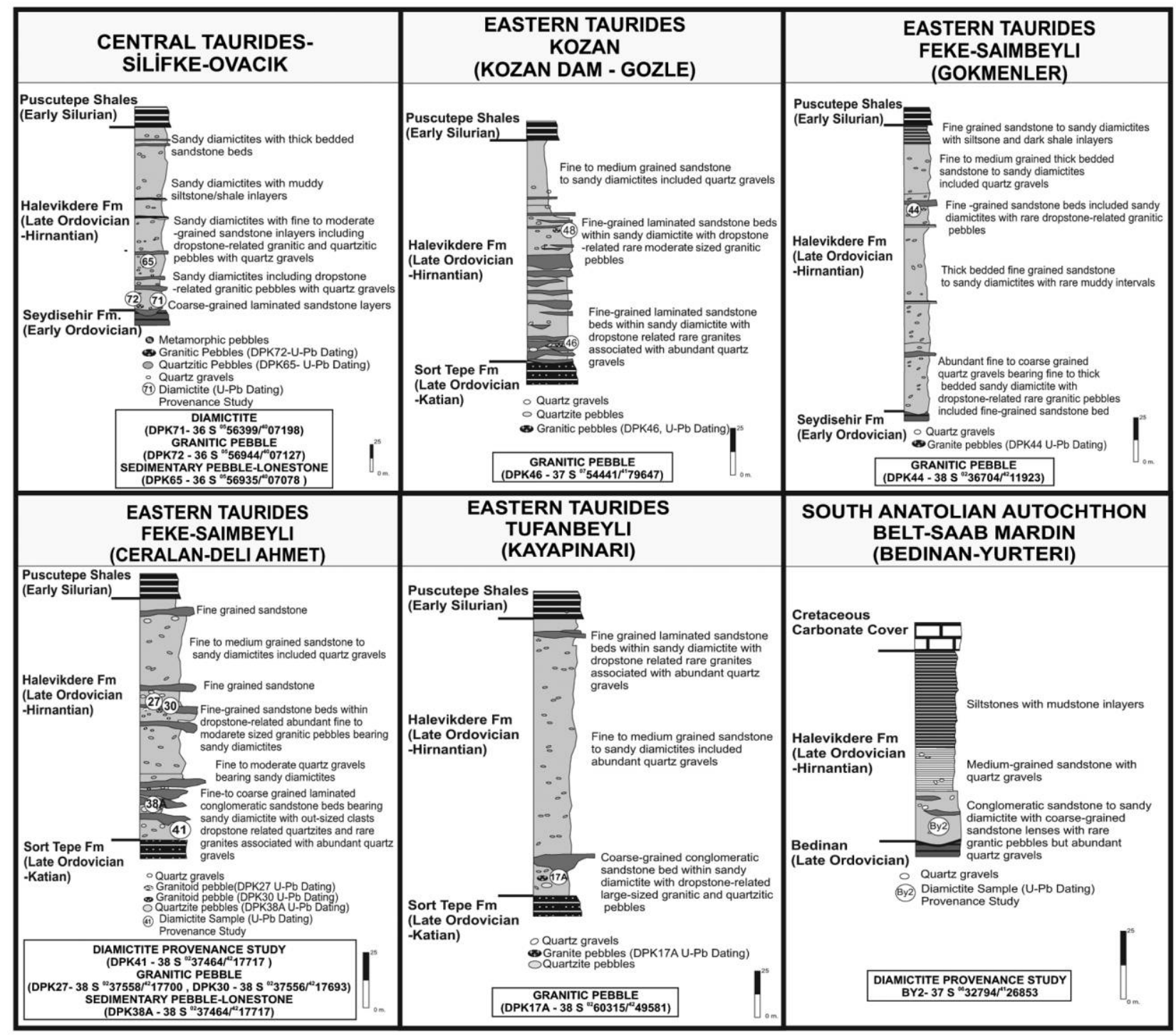

Figure 3. Columnar section of the Late Ordovician (Hirnantian) successions in the Silifke-Ovac1k (Central Taurides), Kozan-Dam-Gözle (Eastern Taurides [ET]), Gökmenler-Feke-Saimbeyli (ET), Ceralan-Deli Ahmet-Feke-Saimbeyli (ET), Kayapinar1-Tufanbeyli (ET), and Bedinan-Yurteri (Southeast Anatolian Autochthon Belt) areas. Modified from Monod et al. (2003) and Ghienne et al. (2010).

than the granitic pebbles. Some diamictite samples were prepared in the mineral separation laboratories of the Istanbul Technical University Eurasia Institute (Turkey) and the Department of Geological Research, Mineral Research and General Directorate (Turkey). Zircon separations of the granitic and sedimentary pebbles with weights $<2$ pounds were carried out at the Isotope Geochemistry Laboratory, Department of Geology, University of Kansas. The granitic and siliciclastic pebbles were crushed first in a jaw crusher and then in a shatterbox. They were then ground to smaller than $500 \mu \mathrm{m}$ with a disk mill and passed over a Gemini water table to remove lower-density minerals (e.g., quartz, feldspar). The obtained heavy-mineral concentrates were treated with tetrabromethane (bromoform; density, $\left.2.89 \mathrm{~g} / \mathrm{cm}^{3}\right)$. Magnetic minerals were removed from the heavy-mineral fraction by means of a hand magnet. The remaining heavy minerals were passed through a Frantz magnetic separator at $0.1 \mathrm{~A}$ and then processed consecutively at $0.2,0.4,0.6$, and 1.0 A. Heavy-liquid separation with methylene iodide (density, $3.32 \mathrm{~g} / \mathrm{cm}^{3}$ ) was used on the remaining nonmagnetic fraction to remove apatite. About 50 euhedral/subhedral zircon grains from magmatic samples were then selected 
under a binocular microscope and analyzed for U-Pb to determine their crystallization age. A microsplitter was used to divide the zircon-rich residue to create a representative split of all zircon sizes and morphologies and prevent any bias in the diamictites and lonestones. About 120 zircon grains from each diamictite and lonestone were analyzed for $\mathrm{U}-\mathrm{Pb}$ to determine their provenance. Internal textures of all grains were identified by cathodoluminescence $(\mathrm{CL})$ imaging on a FEI Versa 3-D dual-beam field emission scanning electron microscope at the Microscopy and Analytical Imaging Laboratory of the University of Kansas. Only euhedral/subhedral clear zircons from the granitic samples with oscillatory zoning were selected for determining their spots.

The U-Pb ages were determined by LA-ICP-MS using a Thermo Scientific Element II Sector Field ICP-MS. A Photon Machine ANALYTEG.2 193-nm ArF excimer laser was used to ablate 20- $\mu$ m-diameter spots. The laser was set to $20 \%$ energy output for $2.5 \mathrm{~J} / \mathrm{cm}^{2}$ fluency with a $10-\mathrm{Hz}$ repetition rate that produced ablation pits of ca. $15 \mu \mathrm{m}$ depth. The ablated material was carried to the ICP-MS in helium gas at a ca. $0.67 \mathrm{~L} / \mathrm{min}$ flow rate tied into the $\mathrm{Ar}$ sample gas of the ICP. Two natural zircon reference material standards were used for calibration and accuracy checks (GJ1 [Jackson et al. 2004] and Plešovice [Sláma et al. 2008]). Elemental fractionation, downhole fractionation, and calibration drift were corrected by bracketing measurements of unknowns with the GJ1 reference material and data reduction using the VizualAge data reduction scheme (Petrus and Kamber 2012) for the IOLITE software package (Paton et al. 2011) operating on the IGOR software platform. It yielded a weighted mean ${ }^{206} \mathrm{~Pb} /{ }^{238} \mathrm{U}$ date of $337.95 \pm 0.42 \mathrm{Ma}(2 \sigma ; n=132 ; \mathrm{MSWD}=1.15)$, within $0.11 \%$ of the $337.13 \pm 0.37 \mathrm{Ma}$ age determined by chemical abrasion thermal ionization mass spectrometry (Sláma et al. 2008). The groups of analyses for separate analytical sessions yielded concordia ages between $335.95 \pm 0.97$ and $340.82 \pm$ $1.00 \mathrm{Ma}$, also within $1 \%$ of the published value. All results were evaluated using the ISOPLOT program (Ludwig 2003) and are plotted as $2 \sigma$ error ellipses on Wetherill (1956) and Tera-Wasserburg (Tera and Wasserburg 1972) concordia diagrams (model 2 ages were used for determining the crystallization ages of DPK27, DPK30, DPK44, and DPK72).

The discordance percentages of the analyzed spots were determined as described in Gürsu et al. (2015). The bin widths used on the histograms are $20 \mathrm{Ma}$ for dates between 0.45 and $1.0 \mathrm{Ga}$ and $50 \mathrm{Ma}$ for dates between 1.0 and $3.2 \mathrm{Ga}$. The assigned ages with errors of the major peaks on the probability density diagrams were determined from weighted means of ${ }^{206} \mathrm{~Pb} /{ }^{238} \mathrm{U}$ dates for dates younger than $1.0 \mathrm{Ga}$ and ${ }^{207} \mathrm{~Pb} /{ }^{206} \mathrm{~Pb}$ dates for dates older than 1.0 Ga. Kernel density diagrams and significant peaks were calculated using the software program DensityPlotter (ver. 6.4; Vermeesch 2012).

For whole-rock geochemical analyses, samples were prepared using an agate mortar after grinding and sieving. Six powders of granitic samples were sent to ACME Labs (Canada) to determine major elements, trace elements, and rare earth elements (REEs) to identify their petrogenetic features.

\section{Results}

The mineralogy and petrographic studies show that all granitic pebbles except DPK44 and DPK72 have undergone low-grade metamorphism and deformations that are exemplified by studying the textural and mineralogical changes by polarized microscopy.

Geochronology of the Granitic Pebbles. Results of the LA-ICP-MS U-Pb analyses are given in table S1 (tables S1-S3 are available online).

DPK17A is a subrounded coarse-grained metagranitic pebble. Forty-eight analyses were performed on 42 zircon grains, which gave a range of ${ }^{206} \mathrm{~Pb} /{ }^{238} \mathrm{U}$ ages from 785 to $868 \mathrm{Ma}$ (table S1). The euhedral/subhedral zircon grains have long to short prismatic forms, are colorless to light beige/beige, are transparent, and display oscillatory zoning (fig. 4). Th/U ratios of the analyzed zircon grains range from 0.28 to 0.68 , and they are less than $2 \%$ discordant (table S1). A concordia age from the four youngest zircons (DPK17A-58-1r, DPK17A-59-1r, DPK17A-71-1r, and DPK17A-139-2c) yields $789.5 \pm 3.7 \mathrm{Ma}$ (MSWD = 0.82 ) and is evaluated as its crystallization age (fig. 4). No xenocrystic zircon grains older than $870 \mathrm{Ma}$ were found in this granitic pebble.

DPK27 is a fine-grained, deformed, subrounded metagranitic (protomylonitic) pebble. The zircons are long to short prismatic, light beige to beige, and transparent (rarely semitransparent), and they display oscillatory zoning with partly recrystallized domains and rarely with complex zoning. Th/U ratios vary from 0.28 to 1.45 , except for four spots that are higher than average (ranging from 6.4 to 58.2 ), which probably resulted from radiation damage. The 44 concordant spots analyzed on 41 zircon grains yield dates from 496.4 to $2520 \mathrm{Ma}$ with a gap between 1042 and $2192 \mathrm{Ma}$, which are plotted on a Tera-Wasserburg concordia diagram (fig. 5A). The four youngest dates (from 496.4 to $534.8 \mathrm{Ma}$ ) are not considered to represent the crystallization age of the granitic pebble due to their high $\mathrm{U}$ con- 


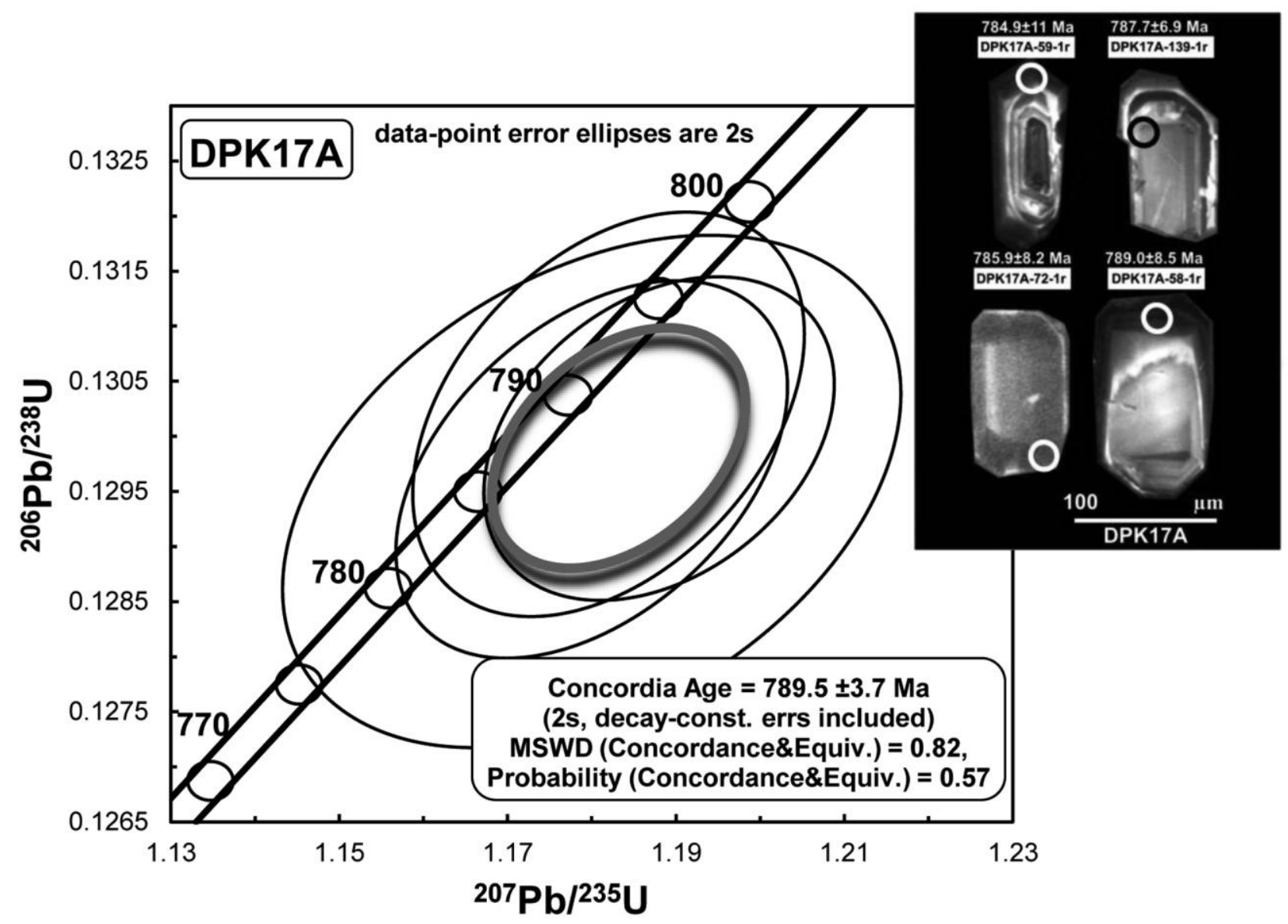

Figure 4. Concordia diagram of the crystallization age of the zircons of granitic pebble DPK17A and cathodoluminescence images of the dated spots.

tents (>650 ppm), which display a negative trend among U-Th contents, and their ages indicate radiation damage and recent lead loss. The six youngest zircon grains among the oscillatory zoning spot grains yield a model 2 (Ludwig 2003) upper intercept age of $560 \pm 26 \mathrm{Ma}( \pm 95 \%$ confidence; MSWD $=$ 0.66; fig. $5 B$ ), but two overlapping concordant analyses (DPK27-12-1r and DPK27-73-1r) from this group give a much better defined concordia age of $576.7 \pm$ $5.7 \mathrm{Ma}(\mathrm{MSWD}=0.43)$ that is interpreted as the crystallization age of this granitic pebble (fig. $5 \mathrm{C}$ ).

DPK30 is a subrounded metagranite pebble. Fiftyeight analyses on 50 zircons were obtained from this sample. Most of the grains are euhedral/subhedral, long to short prismatic, colorless to light beige, and transparent. CL images show well-developed oscillatory zoning with abundant apatite and fluid inclusions (fig. 6). The $U$ and Th contents of the analyzed spots vary from 33.3 to 389 and from 12.8 to $356 \mathrm{ppm}$, respectively, yielding $\mathrm{Th} / \mathrm{U}$ ratios from 0.30 to 1.22 . All analyses are less than $3.5 \%$ discordant. Thirtyseven analyses define a model 2 (Ludwig 2003) dis- cordia line with an upper intercept age at $717.5 \pm$ 8.0 Ma (MSWD $=1.08)$, interpreted as the crystallization age of this granitic pebble (fig. 6).

DPK44 is a subrounded coarse-grained monzogranitic pebble, and 40 analyses on 37 zircons were performed with ages ranging from 441.2 to $888 \mathrm{Ma}$. The analyzed zircons are long to short prismatic, light beige to beige, and transparent/semitransparent. CL images show well-developed oscillatory zoning, especially in the outer rims (fig. $7 B$ ). The grains have abundant xenocrystic cores and fluid inclusions. The xenocrystic cores range in age from 691.7 to $888.0 \mathrm{Ma}$, with the majority being Cryogenian in age, except one analysis at 888.0 Ma. The youngest dates between ca. 440 and $570 \mathrm{Ma}$ have high $\mathrm{U}$ contents $>650$ $\mathrm{ppm}$ ) and are up to $3 \%$ discordant, likely due to radiation damage. Twenty-one spots yield a model 2 (Ludwig 2003) upper intercept age of $638 \pm 14 \mathrm{Ma}$ $(\mathrm{MSWD}=2.4)$ that is not represented by a single age population due to its high MSWD (fig. $7 A$ ). The five youngest concordant analyses within this group yield a concordia age of $576.5 \pm 3.3 \mathrm{Ma}(\mathrm{MSWD}=$ 

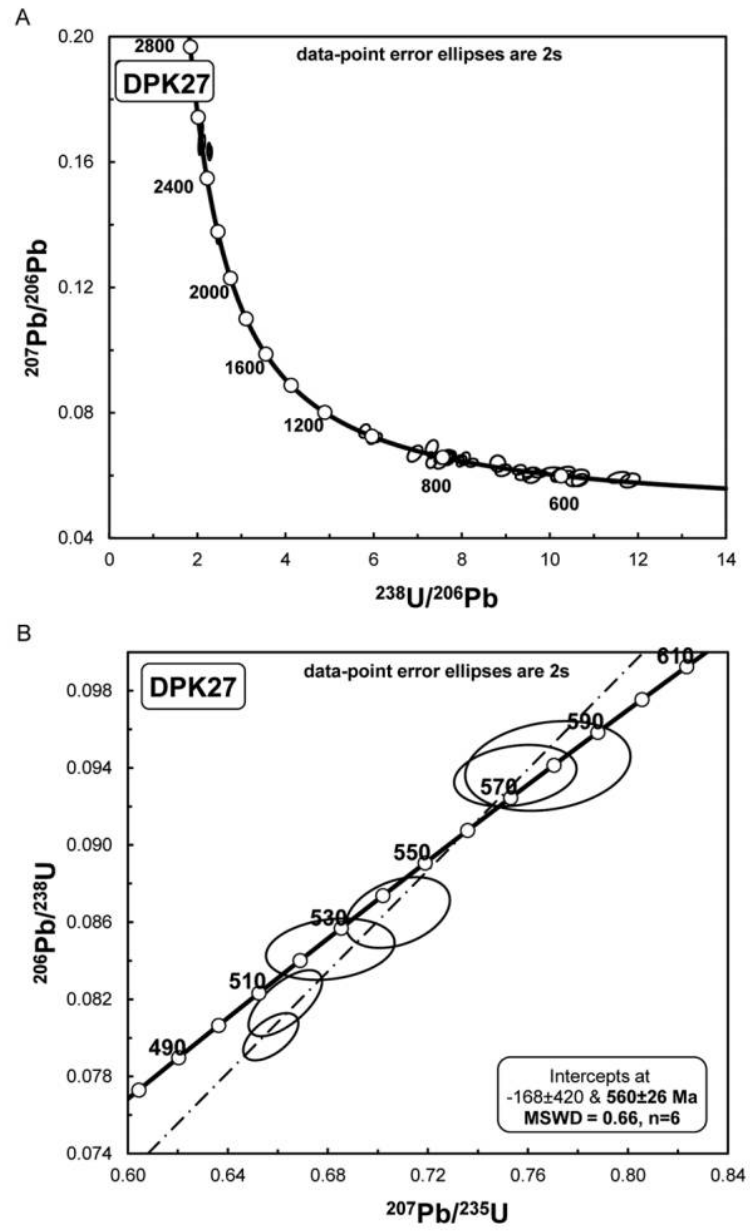

C

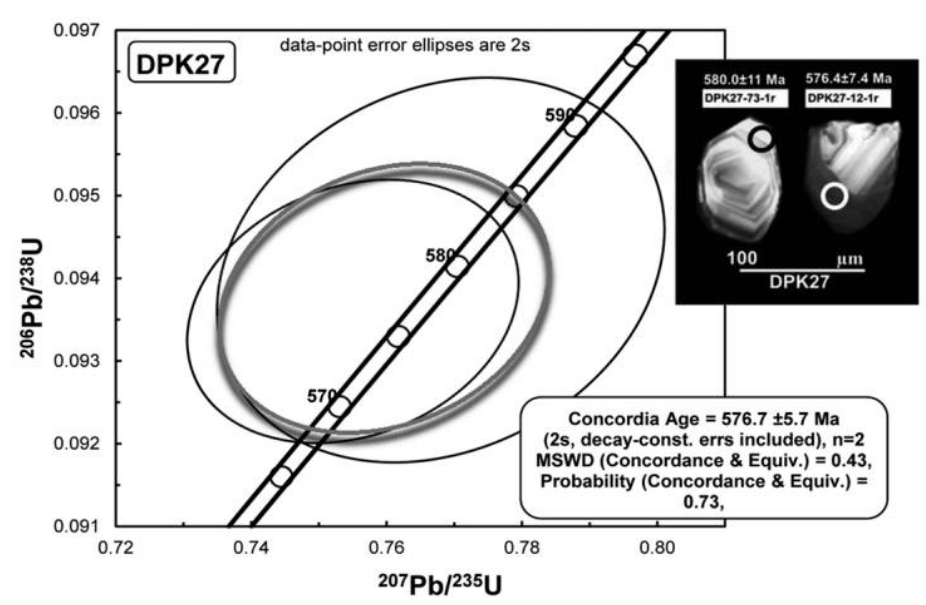

Figure 5. $A, B$, Tera-Wasserburg and discordia diagrams of the granitic pebble DPK27. $C$, Concordia diagram for the crystallization age of zircons based on the youngest two data points and cathodoluminescence images of the dated spots.

1.7), evaluated as the crystallization age of the monzogranitic pebble (fig. $7 B$ ).

DPK46 is a subrounded coarse-grained metagranitic pebble. Forty-three analyses were conducted on 33 zircons with ages ranging from 946 to $1040 \mathrm{Ma}$.
The analyzed grains are long to short prismatic, light beige to beige, and transparent/subtransparent, and they display oscillatory zoning (fig. 8). The Th/U ratios range from 0.34 to 1.03 . Sixteen spots yield a $964.6 \pm 4.6 \mathrm{Ma}(\mathrm{MSWD}=1.8)$ concordia age, in- 

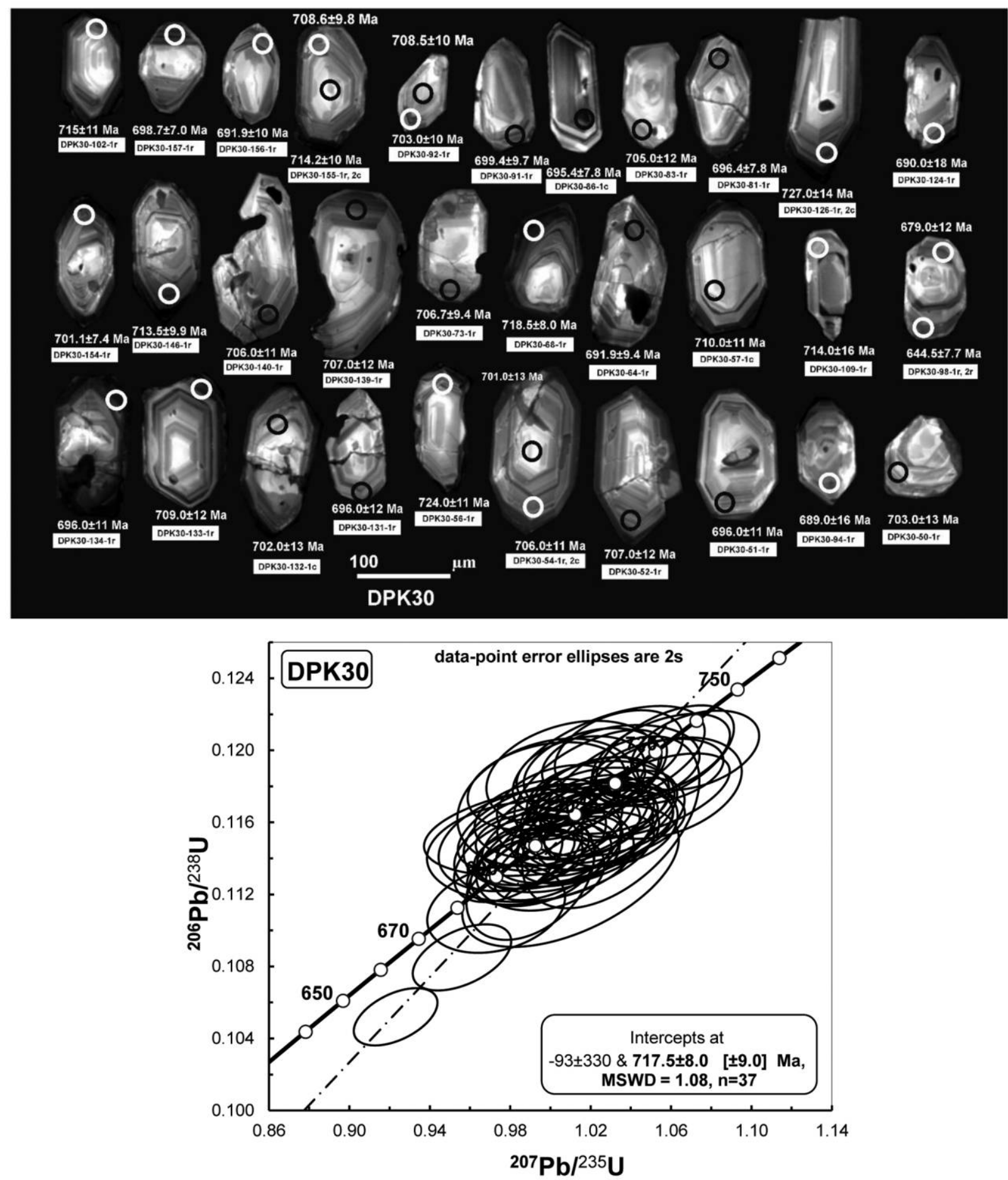

Figure 6. Discordia diagram for the crystallization age of the zircons of granitic pebble DPK30, with cathodoluminescence images of the dated spots.

terpreted to represent the crystallization age of the granitic pebble (fig. 8). Only one pre-Tonian xenocryst age (ca. $1050 \mathrm{Ma}$ ) was determined from this sample.

DPK72 is a subrounded coarse-grained hydrothermally altered granitic pebble. Forty-four analyses were performed on rims and cores of 44 grains, with nearconcordant dates ranging from ca. 560 to $810 \mathrm{Ma}$. The zircon grains are long to short prismatic, colorless to light beige, and transparent/semitransparent, and they display well-developed oscillatory zoning (fig. 9). Th/U ratios of the analyses range 
A

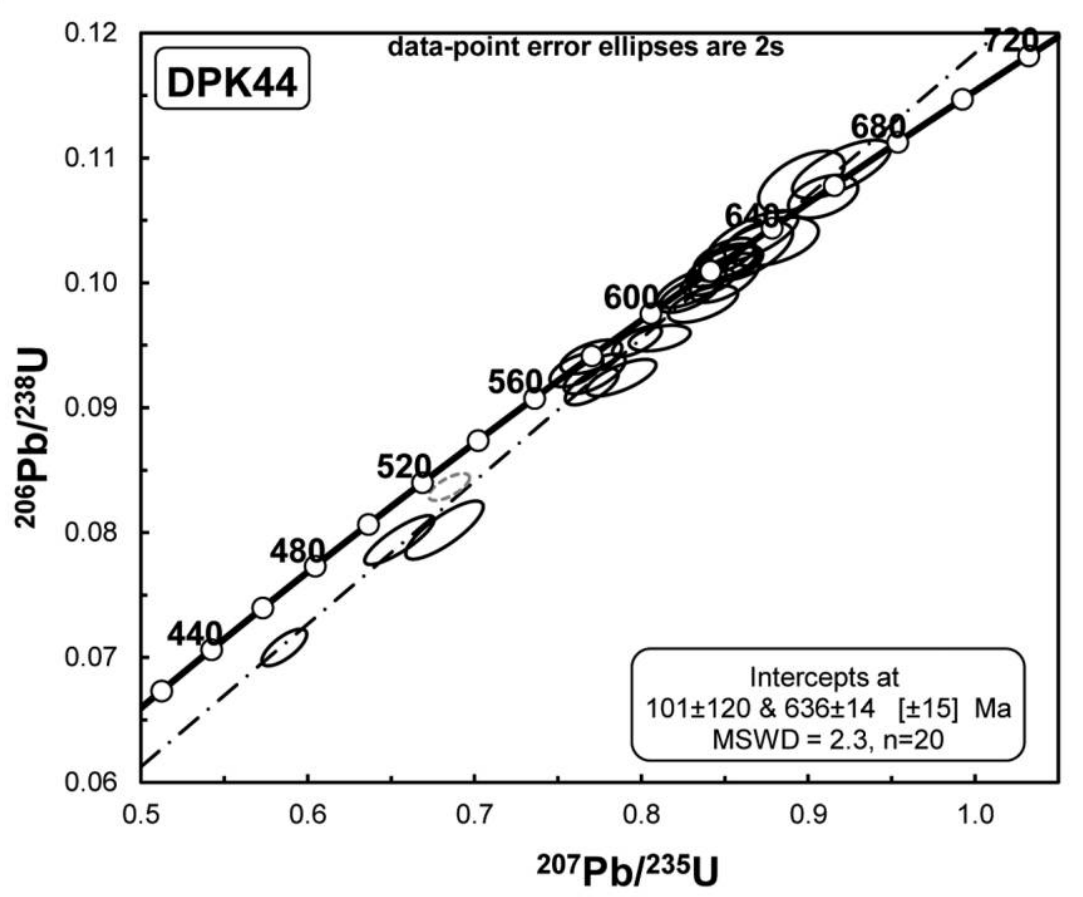

B

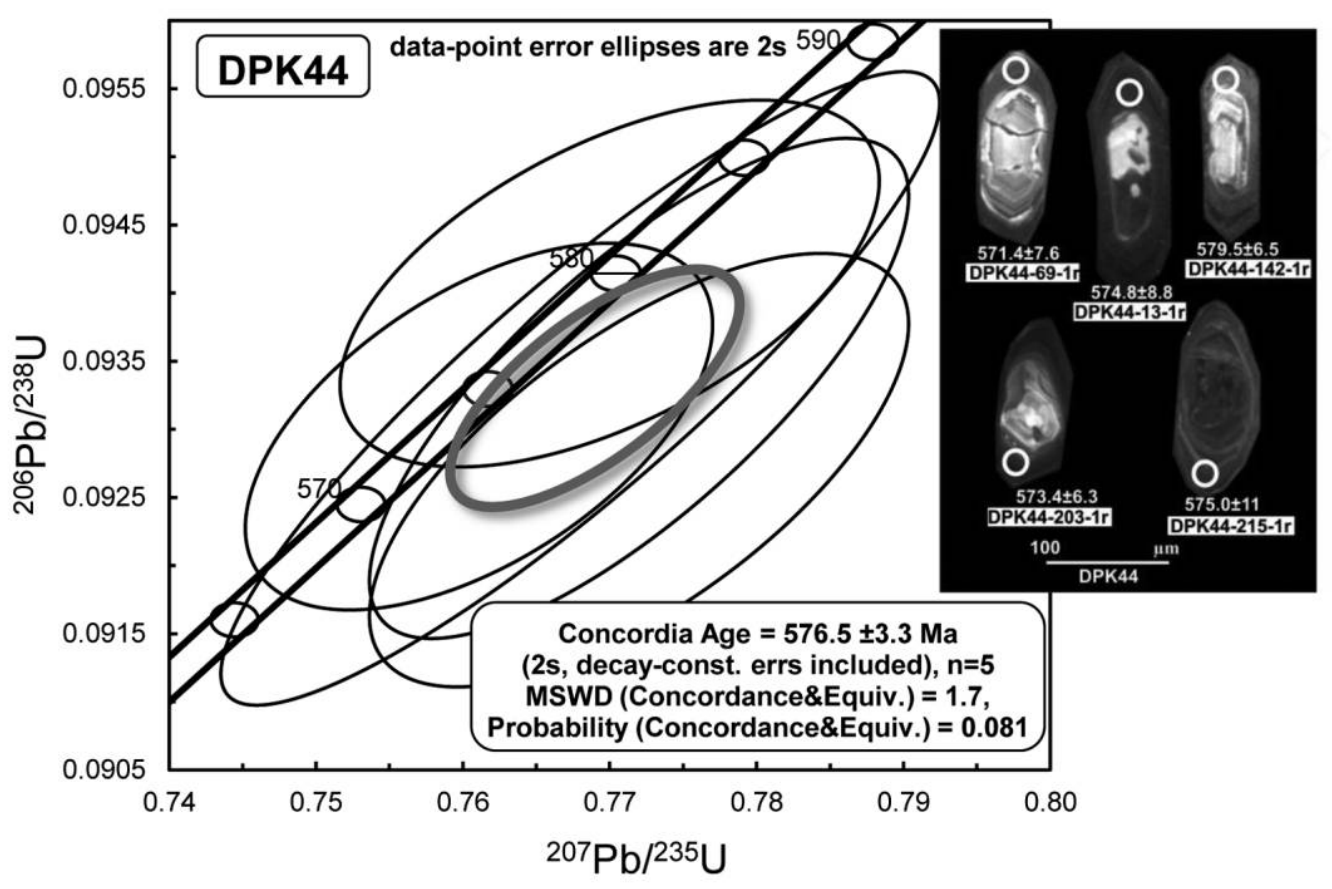

Figure 7. A, Discordia diagram of all analyzed zircons from granitic pebble DPK44. $B$, Concordia diagram for the crystallization age of zircons from granitic pebble DPK44 and cathodoluminescence images of the dated spots.

from 0.34 to 1.50 . The 39 youngest analyses yield a model 2 (Ludwig 2003) upper intercept age of $598.4 \pm$ $7.5 \mathrm{Ma}$ (MSWD = 1.12; fig. 9), interpreted to represent the crystallization age of the metagranitic pebble.
The ages of the studied granitic pebbles are all Neoproterozoic, which supports the notion that they were derived from a juvenile Pan-African terrane and not from older terranes that were reworked during the Pan-African orogenic cycle. 

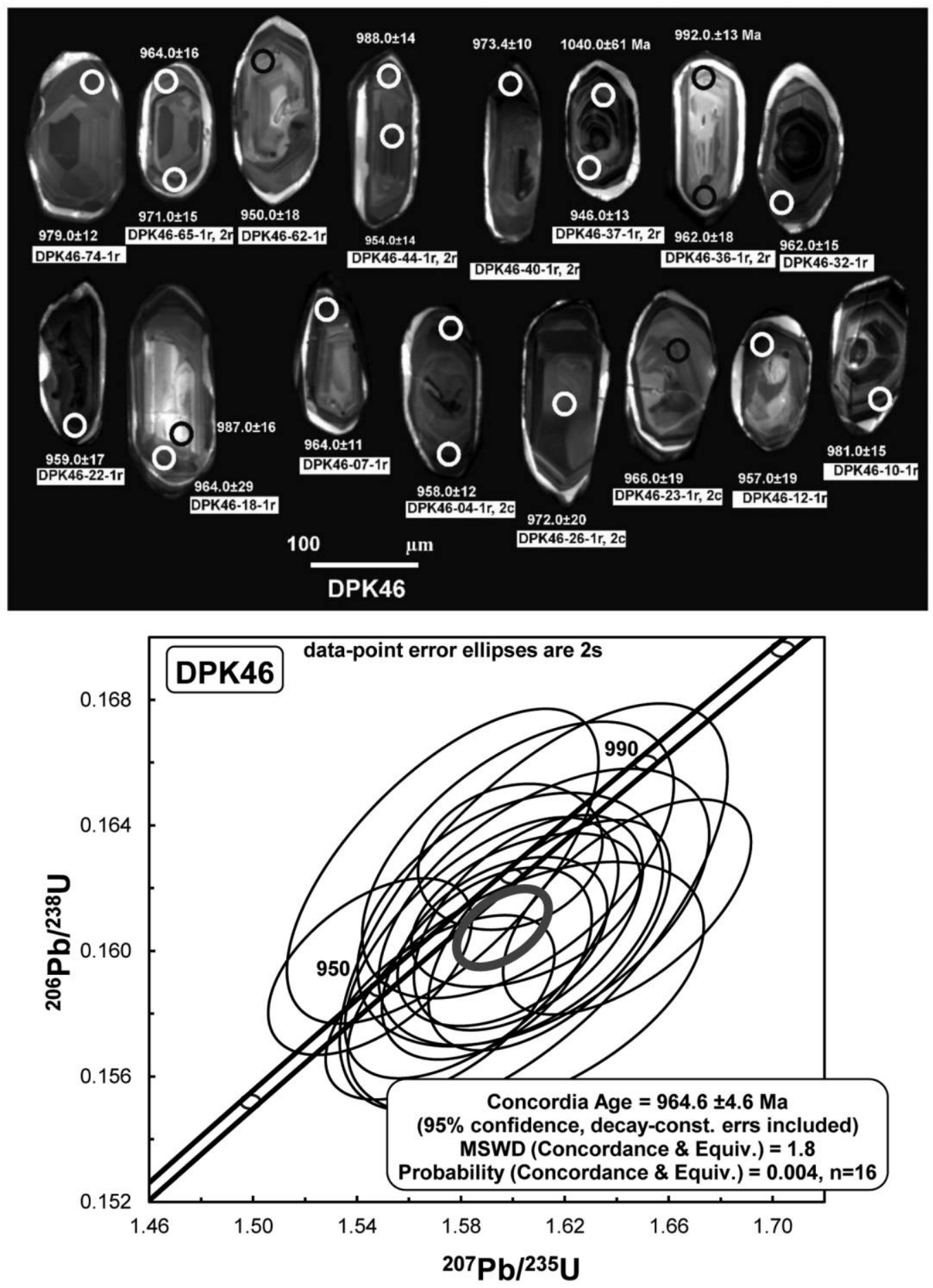

Figure 8. Concordia diagram for the crystallization age of the zircons from granitic pebble DPK46, with cathodoluminescence images of the dated spots.

Geochronology of the Sedimentary Diamictites and Lonestones. The detailed mineralogical and petrographical features of the studied diamictites and lonestones are given in section 2 of the appendix. Data on the detrital zircons of the analyzed samples are presented in tables S2 and S3. For determining the provenance of the diamictites and lonestones, we focused on selecting and analyzing the inherited cores that are free from overgrowths and display internal zonation. The detrital zircon results are 


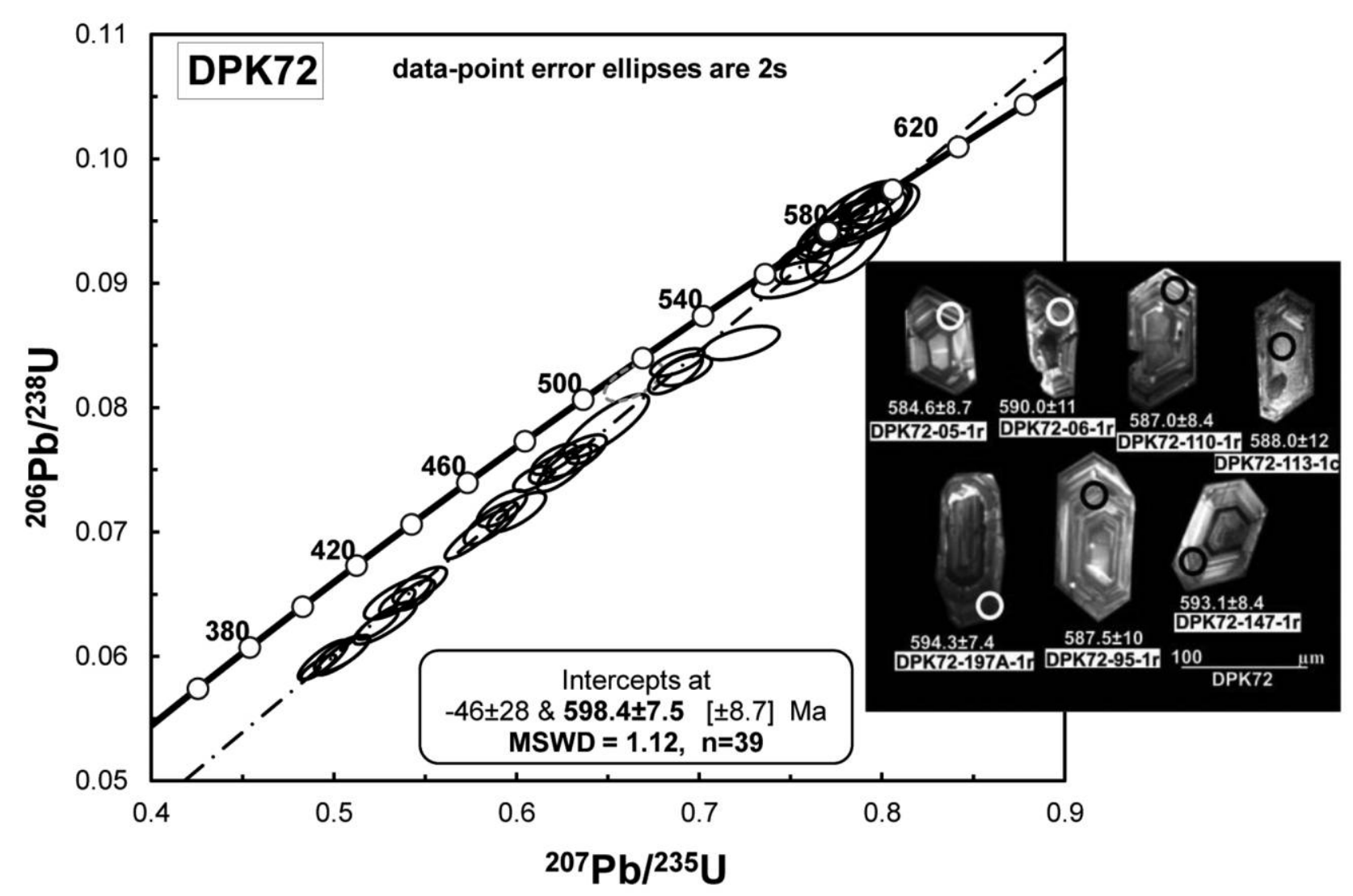

Figure 9. Discordia diagram for the crystallization age of the zircons from granitic pebble DPK72, with cathodoluminescence images of the dated spots.

plotted on Tera-Wasserburg concordia and probability density diagrams. The results are discussed in the following sections.

U-Pb Ages of Zircons from the Diamictite Matrix. $B Y 2-Q-D i a m i c t i t e(S A A B)$. One hundred six analyses were conducted on 97 detrital zircon grains by LA-ICP-MS (table S2). Eleven of them are strongly discordant $(>5 \%)$, and the rest yield dates between 524.7 and $2617 \mathrm{Ma}$. The analyzed detrital zircons are long to short prismatic, light beige to beige, subrounded to rounded, and transparent to semitransparent and display oscillatory zones, but some of them have patchy, complex zones and recrystallized domains, especially in the rim parts. They have inherited cores (fig. S1 $A$; fig. $\mathrm{S} 1$ is available online). The analyzed zircon grains are generally small, ranging from 40 to $110 \mu \mathrm{m}$ in length. Th/U contents of the analyzed zircons range from 0.13 to 1.3 (except for one core with a very low Th/U of 0.05 and two core analyses with high values of 1.7 and 1.9). The results are plotted on a Tera-Wasserburg diagram (fig. 10A). The two youngest analyses yield a concordia age of $530.5 \pm 5.3 \mathrm{Ma}(\mathrm{MSWD}=0.83$; fig. $10 B)$.
The age spectrum of the analyzed detrital zircons is dominated by Neoproterozoic ages, followed by Mesoproterozoic ages, Paleoproterozoic ages, and Neoarchean ages (table 1; fig. 11). The Neoproterozoic ages are concentrated in the Cryogenian (dominant) with equal proportions of Ediacaran and Tonian ages (table 1; fig. 11). Ages of the major peaks in the probability density plots were determined at $674.2 \pm$ 2.9 Ma as well as at 597.4 $\pm 4.1,622.1 \pm 9.3,657.2 \pm$ 3.3, $697.4 \pm 3.8$, and $995.4 \pm 4.3 \mathrm{Ma}$ (fig. 11). A high abundance of rounded/subrounded Stenian zircons is present at $1050 \pm 10 \mathrm{Ma}$ (fig. 11). Abundant Grenvillean-type input is indicated by $32.2 \%$ of all analyzed zircons, which are split equally between Tonian and Stenian age grains (table 1; fig. 11). There is a clear age gap between 1.14 and $1.75 \mathrm{Ga}$, except for one analyses at $1.46 \mathrm{Ga}$ (fig. 11). A peak of Orosirian age is present at $1986 \pm 14 \mathrm{Ma}$; some (i.e., five) analyses yield dates around $2.1 \mathrm{Ga}$, and three analyses have Neoarchean ages (table 1; fig. 11).

DPK41-Diamictite-ET. One hundred fourteen LA-ICP-MS analyses were conducted on 95 zircons. Seven of the analyzed zircons are more than $5 \%$ 
A

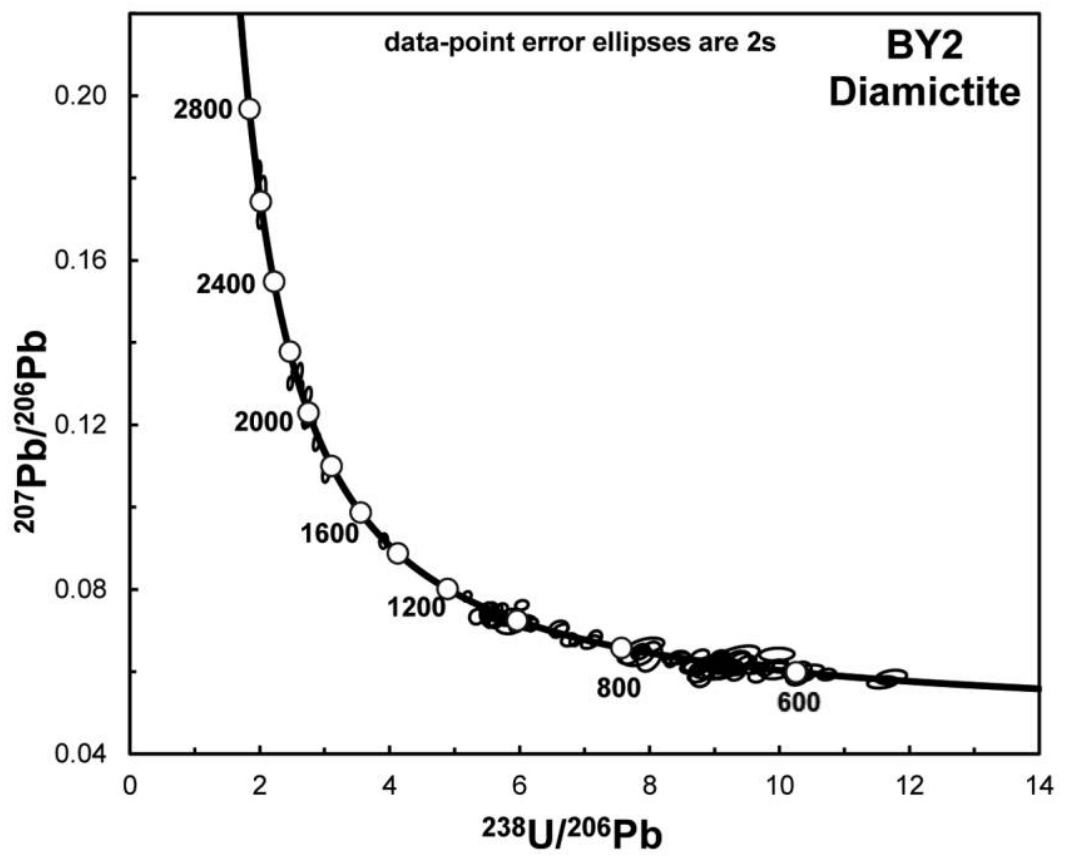

B

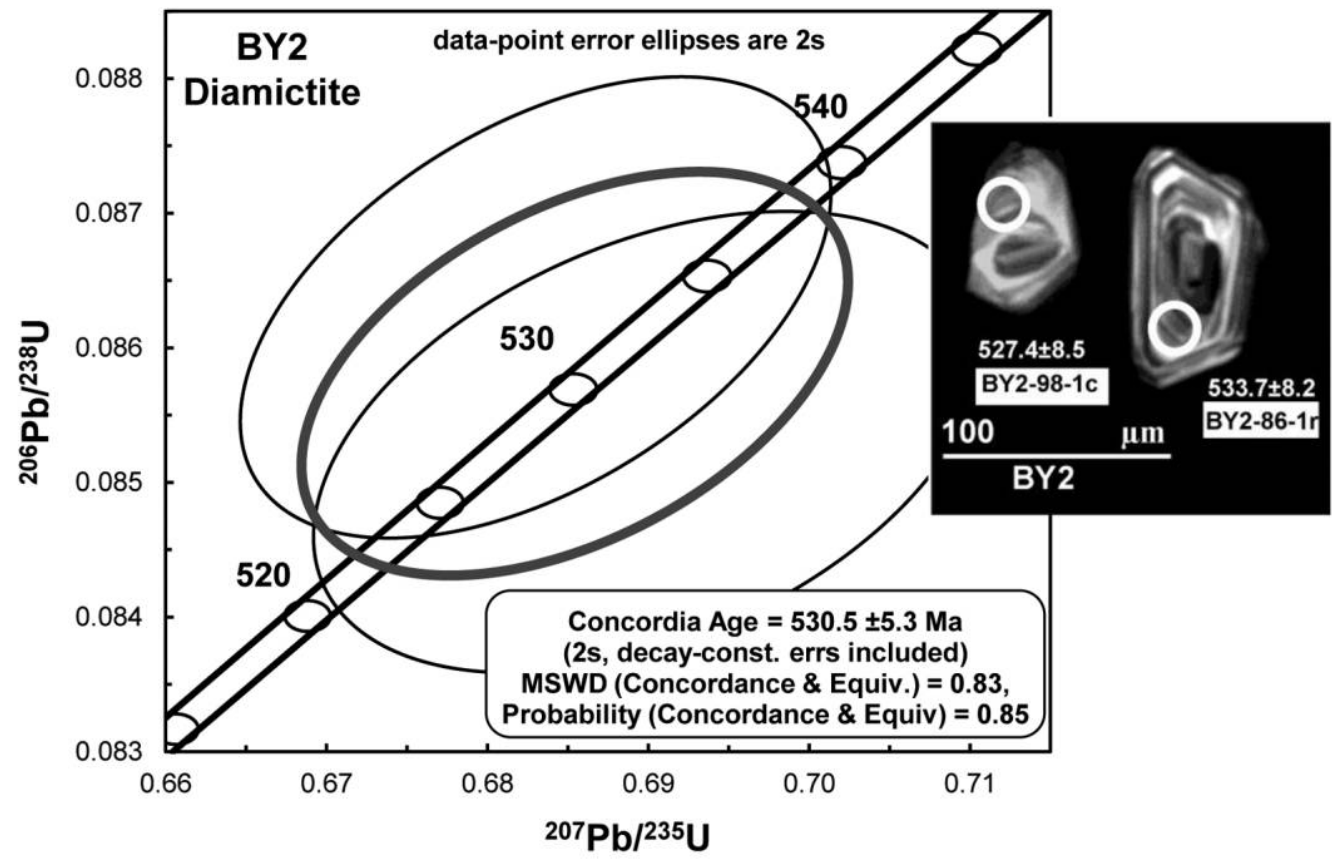

Figure 10. A, Tera-Wasserburg diagram of diamictite sample BY2. B, Concordia diagram of the youngest analyses from diamictite BY2, with cathodoluminescence images of the youngest spots.

discordant and were not used for further interpretation (table S2). The concordant analyses range from 494 to $2667 \mathrm{Ma}$ and are plotted as $2 \sigma$ error ellipses on a Tera-Wasserburg diagram (fig. 12A). The grain size of the zircons is generally $<100 \mu$, and they are rounded/subrounded, light beige to beige and brown in color, and transparent/semitransparent, and they mainly display oscillatory zones with abundant in- 
Table 1. Percentages of U-Pb Age Zircon Populations of the Diamictites and Lonestones

\begin{tabular}{|c|c|c|c|c|c|}
\hline & \multicolumn{3}{|c|}{ Diamictites } & \multicolumn{2}{|c|}{ Lonestones } \\
\hline & BY2, SAAB (\%) & DPK41, ET (\%) & DPK71, CT (\%) & DPK38A, ET (\%) & DPK65, CT (\%) \\
\hline \multicolumn{6}{|l|}{ Neoproterozoic: } \\
\hline Ediacaran & 10.80 & 27.60 & 12.70 & 14.80 & 29.10 \\
\hline Cryogenian & 38.70 & 28.60 & 45.20 & 54.40 & 32.70 \\
\hline Tonian & 16.10 & 13.30 & 18.30 & 19.30 & 15.50 \\
\hline Total & 65.60 & 41.90 & 76.20 & 88.50 & 77.30 \\
\hline \multicolumn{6}{|l|}{ Mesoproterozoic: } \\
\hline Stenian & 16.10 & 7.60 & 4.00 & 2.30 & .90 \\
\hline Ectasian & & 2.90 & $\ldots$ & $\ldots$ & .90 \\
\hline Calymmian & 1.07 & $\ldots$ & $\ldots$ & $\ldots$ & $\ldots$ \\
\hline Total & 17.17 & 10.50 & 4.00 & 2.30 & 1.80 \\
\hline \multicolumn{6}{|l|}{ Paleoproterozoic: } \\
\hline Statherian & 1.07 & & & & \\
\hline Orosirian & 6.50 & 2.90 & 6.30 & 1.10 & 4.50 \\
\hline Rhyacian & 5.40 & .95 & 5.50 & $\ldots$ & 3.60 \\
\hline Siderian & $\ldots$ & 7.60 & 3.20 & $\ldots$ & 4.50 \\
\hline Total & 12.97 & 11.45 & 15.00 & 1.10 & 8.10 \\
\hline Neoarchean & 4.30 & 5.70 & 4.00 & 4.50 & 7.30 \\
\hline Mesoarchean & $\ldots$ & $\ldots$ & .80 & $\ldots$ & $\ldots$ \\
\hline
\end{tabular}

Note. $\mathrm{CT}=$ Central Taurides; $\mathrm{ET}=$ Eastern Taurides; SAAB $=$ Southeast Anatolian Autochthon Belt.

herited cores and fluid inclusions. Only a few show complex zoning and partly recrystallized domains (fig. $\mathrm{S} 1 B$ ). Th/U ratios of the analyzed zircons range from 0.1 to 2.1 , and only two analyses are above 1.3 ; only three analyses have Th/U below 0.1 . The two youngest concordant analyses define a concordia age at $499.1 \pm 4.2 \mathrm{Ma}(\mathrm{MSWD}=0.58$; fig. $12 B)$. The age spectrum of the analyzed detrital zircons is split into four groups as Neoproterozoic, Mesoproterozoic, Paleoproterozoic, and Neoarchean ages (table 1; fig. 11). The dominant group of Neoproterozoic age has an equal number of Ediacaran and Cryogenian ages with lesser Tonian dates (table 1; fig. 11). The histogram age peaks on the Cryogenian zircons form a distinct group of high abundance at $639.4 \pm 3.4 \mathrm{Ma}$ and display a peak at $774.2 \pm 4.7 \mathrm{Ma}$ (fig. 11). The Ediacaran and Stenian zircons yield significant histogram age peaks at $542.6 \pm 7.6,639.4 \pm 3.4,774.2 \pm$ $4.7,864 \pm 11,995.4 \pm 9.9$, and $1039 \pm 17 \mathrm{Ma}$ (fig. 11). Grenvillean-type input is present, as $20.9 \%$ of the analyzed zircons split into Tonian and Stenian dates. Their percentage is lower than in sample BY2 (table 1; fig. 11). This sample shows a long age gap between 1250 and $1820 \mathrm{Ma}$ and distinct histogram age peaks at $2477 \pm 11,2506 \pm 16$, and $2542 \pm 14 \mathrm{Ma}$ (fig. 11).

DPK71-Diamictite. One hundred thirty-five analyses were obtained from 104 zircon grains. The results range from $560.8 \pm 7.9$ to $2934 \pm 32 \mathrm{Ma}$ and are plotted on a Tera-Wasserburg diagram (fig. 13A). Eight analyses were excluded from further calculations because they are more than $5 \%$ discordant or have very high $U$ content ( $>800 \mathrm{ppm}$ ). The grain sizes of the analyzed zircons range from 35 to $100 \mu \mathrm{m}$. They are long to short prismatic, rounded/subrounded, light beige, beige, brown, and transparent/semitransparent, and they have oscillatory zones with rarely observed patchy and complex zoning (fig. S1A). Th/U ratios of the analyzed zircons are generally between 0.1 and 1.0, with six analyses $\leqq 0.1$ and 13 analyses $\geqq 1.0$. The two youngest analyses define a concordia age of $562.5 \pm 5.4 \mathrm{Ma}$ (fig. $13 \mathrm{~B}$ ), much older than the Ordovician stratigraphic age of the succession in the CT (determined by paleontological evidence; details in Paris et al. 2007). The age spectrum of the detrital zircons forms nine groups of Ediacaran, Cryogenian, Tonian, Stenian, Orosirian, Rhyacian, Siderian, Neoarchean, and Mesoarchean ages (table 1; fig. 11). The high amount of detrital zircons of Tonian and Stenian age is evidence for significant Grenvilleantype input and is similar to the populations of samples BY2 and DPK41 (table 1; fig. 11). The Cryogenian shows two significant histogram age peaks at $801.9 \pm 4.2$ and $662 \pm 5.1 \mathrm{Ma}$, preceded by a younger $616.5 \pm 6.0 \mathrm{Ma}$ histogram age peak in the Ediacaran. Other significant histogram age peaks are $963 \pm 12 \mathrm{Ma}$ in the Tonian, $1026 \pm 24 \mathrm{Ma}$ in the Stenian, $1981 \pm 13 \mathrm{Ma}$ in the Orosirian, and $2496.7 \pm$ 9.1 Ma in the Siderian (fig. 11). There is a significant age gap between 1.05 and $1.98 \mathrm{Ga}$ in this sample.

U-Pb Ages of the Lonestones. DPK38A-Q-Lonestone, from Host Diamictite DPK41 (ET). Ninety-nine spots from 86 detrital zircons were analyzed. Eightynine percent of the analyzed zircon is less than $5 \%$ 
A

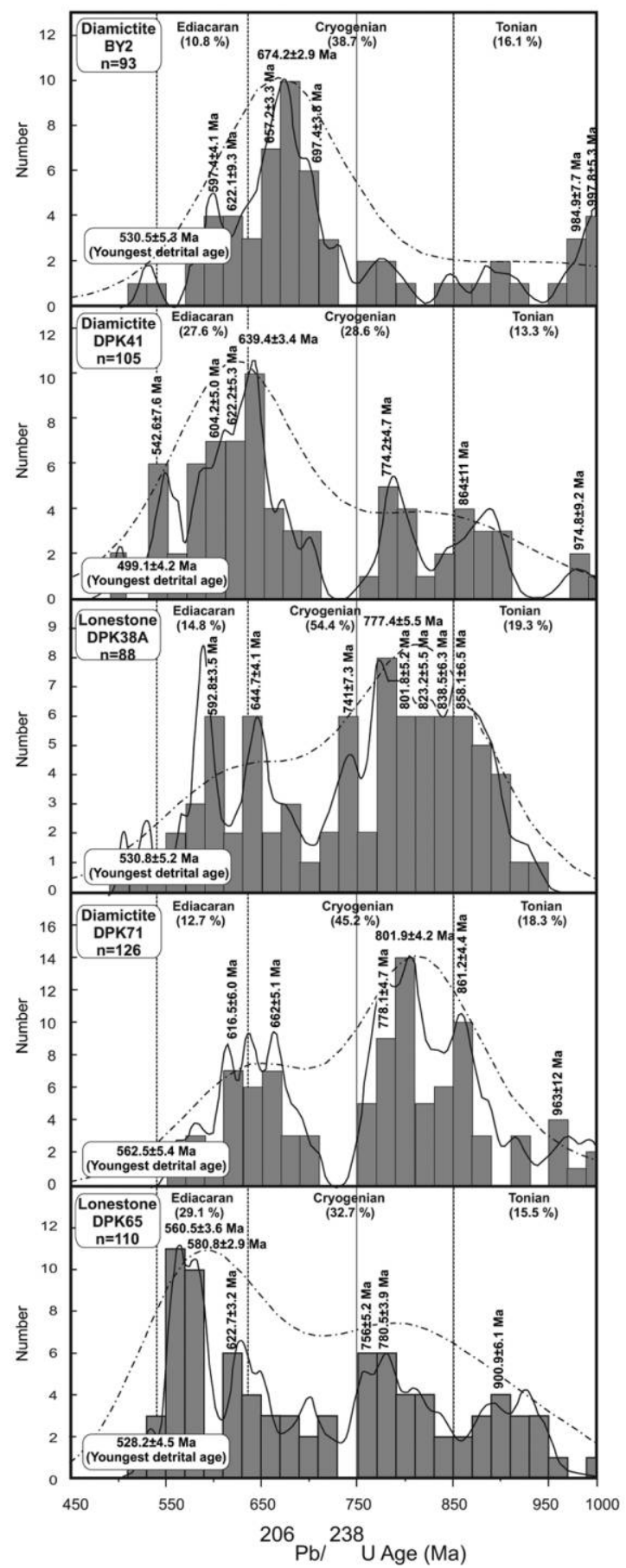

B

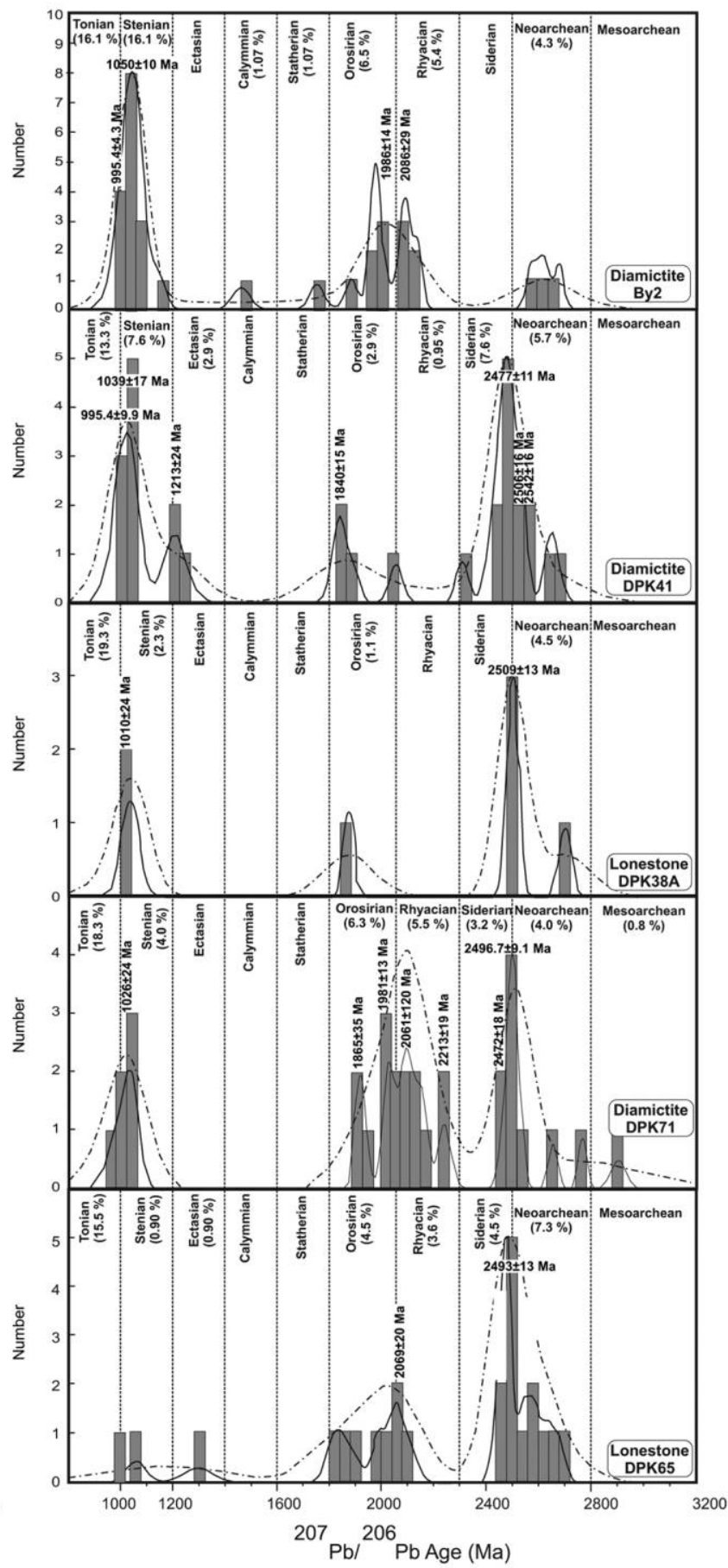

Figure 11. A, Combined binned kernel (discontinuous lines) and probability (continuous lines) density plots of the diamictites and lonestones from the Late Ordovician glacial successions in the Central Taurides, the Eastern Taurides, and the Southeast Anatolian Autochthon Belt for the range of 0.45-1.1 Ga. Bin width: $20 \mathrm{Ma}$. B, Data for the range 0.8-3.2 Ga. Bin width: $40 \mathrm{Ma}$. Frequency bars: only data less than $5 \%$ discordant are plotted; left column: ${ }^{206} \mathrm{~Pb} /{ }^{238} \mathrm{U}$ ages for zircons $<1.0 \mathrm{Ga}$; right column: ${ }^{207} \mathrm{~Pb} / 206 \mathrm{~Pb}$ dates for the analyzed zircons. Kernel density lines are obtained after the calculation schemes of Vermeesch (2012). 


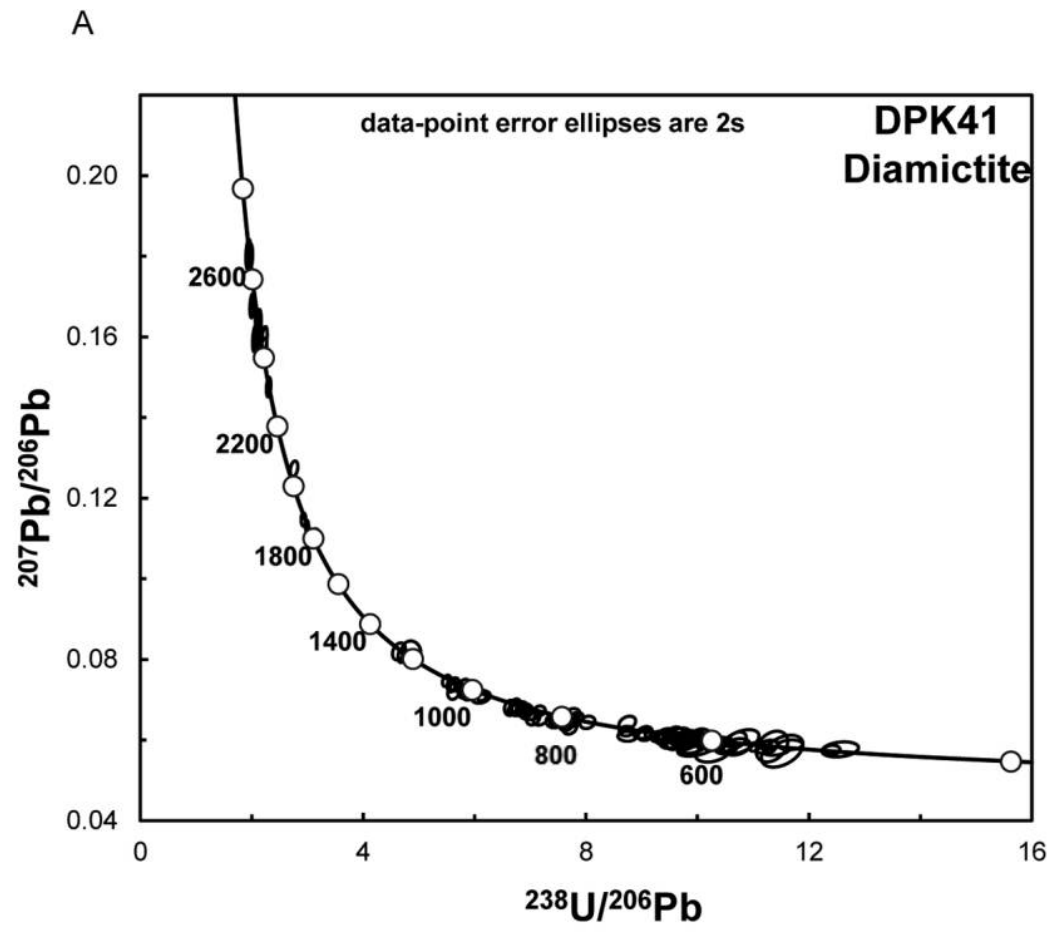

B

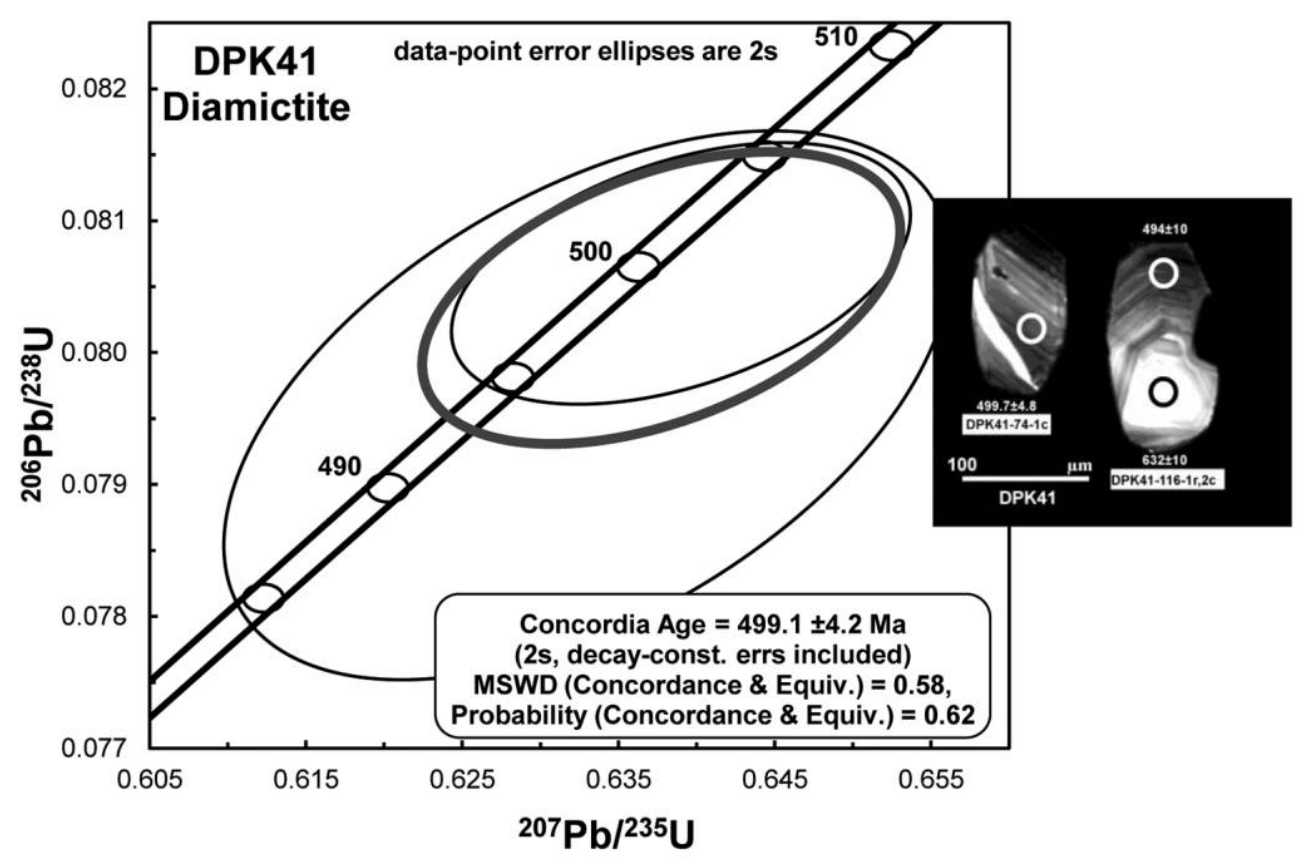

Figure 12. A, Tera-Wasserburg diagram of diamictite sample DPK41. B, Concordia diagram for the youngest analyses from sample DPK41 and cathodoluminescence images of the youngest ages.

discordant, and more discordant analyses were excluded from further calculations (table S3). The results range from $530.8 \pm 5.2$ to $2512 \pm 24 \mathrm{Ma}$ on a TeraWasserburg diagram (fig. 14). The zircons are typical detrital rounded/subrounded grains, long to short pris- matic, light beige to beige, and transparent/semitransparent, and their sizes range from 35 to $95 \mu \mathrm{m}$. CL images of the analyzed zircons display oscillatory zoning near the rims with patchy recrystallized domains and have complex zoning in the cores 


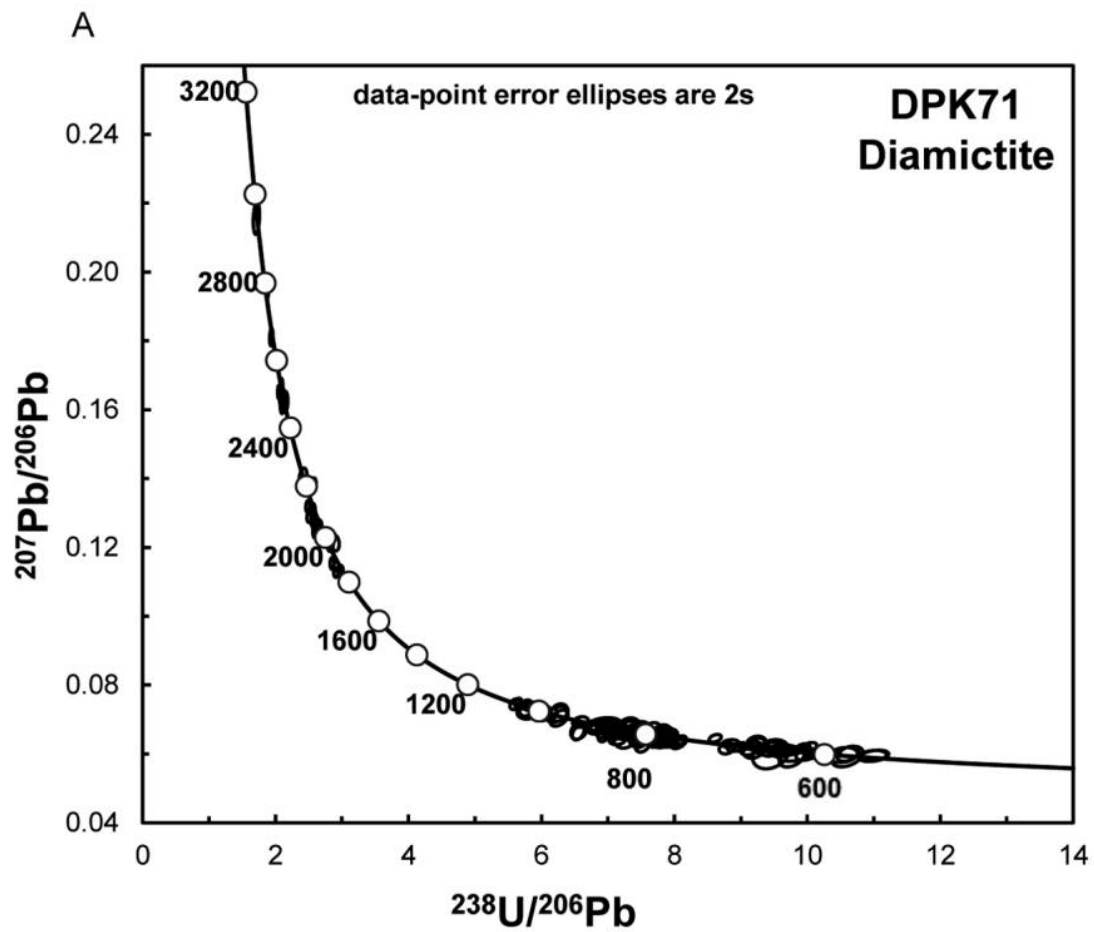

B

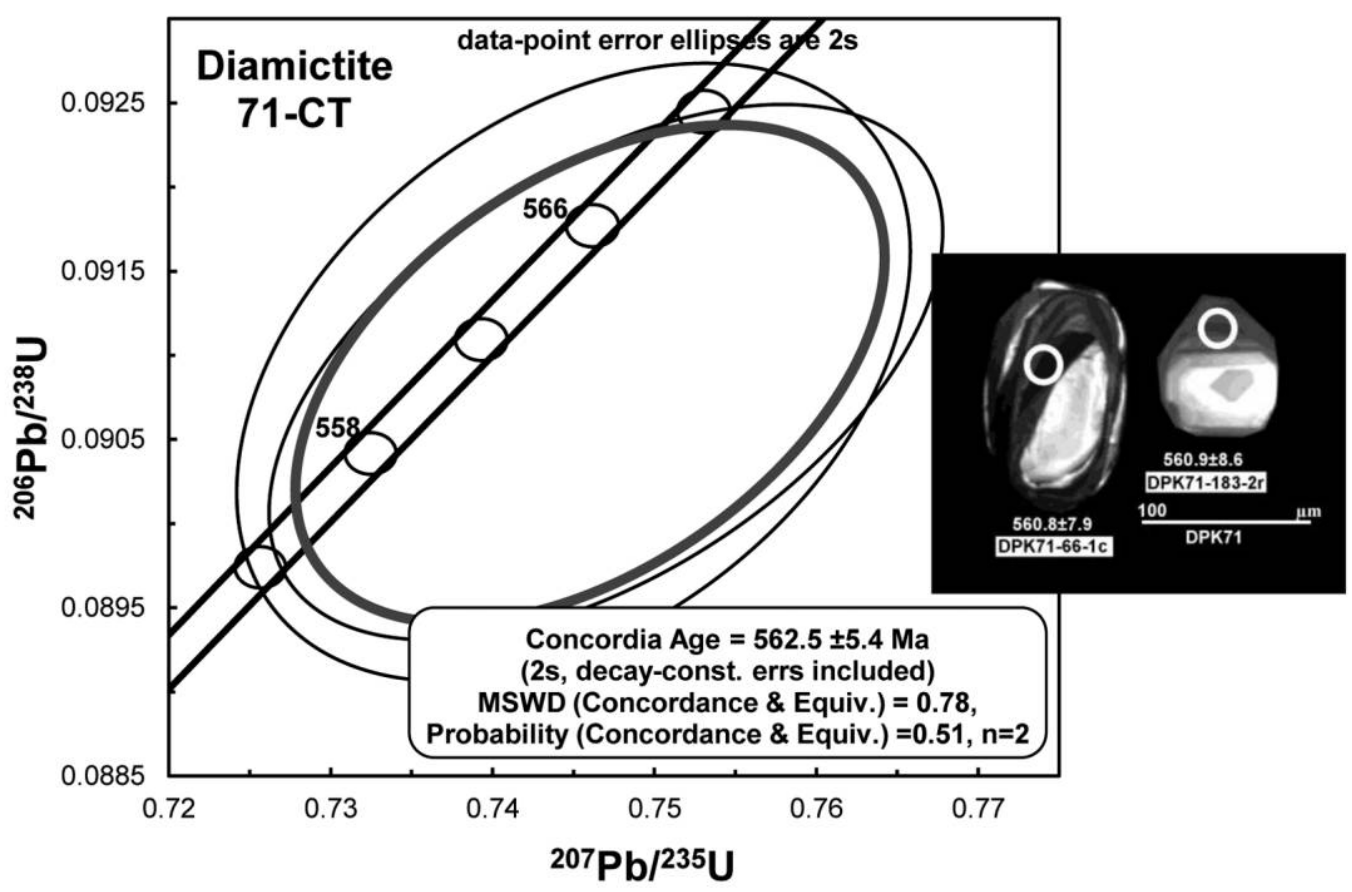

Figure 13. A, Tera-Wasserburg diagram of diamictite sample DPK71. B, Concordia diagram for the youngest analyses from sample DPK71 and cathodoluminescence images of the youngest ages.

(fig. S1C). Th/U ratios of the concordant analyses range from 0.01 to 1.66 ; the age results are plotted in a combined histogram, probability density, and kernel density diagram (fig. 11). The youngest ${ }^{206} \mathrm{~Pb} /{ }^{238} \mathrm{U}$ zircon age from DPK38A-100-1c spot yields an age of
$530.8 \pm 5.2 \mathrm{Ma}$ in the sample. The U-Pb ages are concentrated in the Neoproterozoic, with fewer amounts in the Mesoproterozoic, Paleoproterozoic, and Neoarchean (table 1; fig. 11). Significant histogram age peaks are present at $592.8 \pm 3.5$ (Ediacaran), 


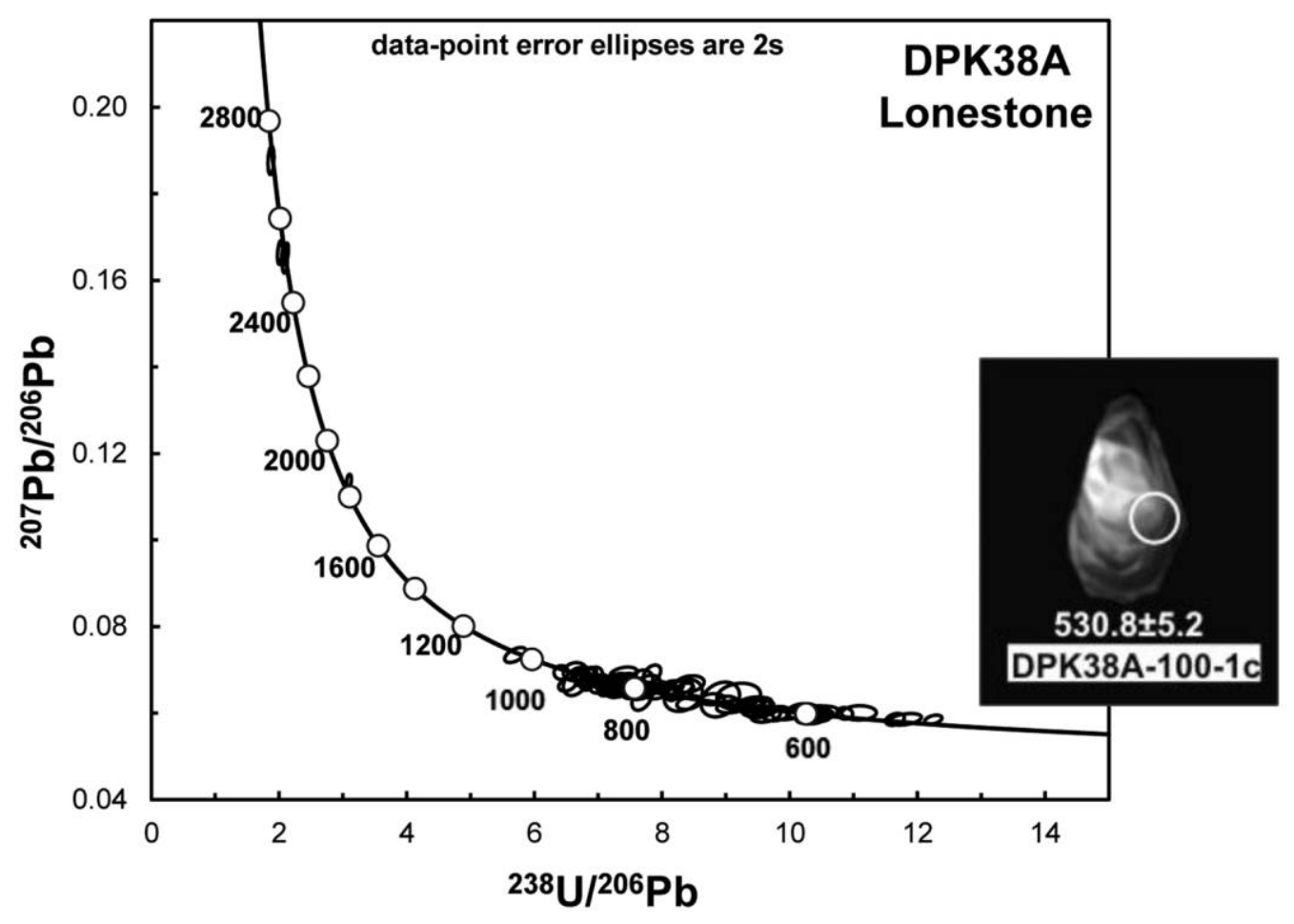

Figure 14. Tera-Wasserburg diagram of lonestone sample DPK38A and cathodoluminescence image of the youngest age.

$644.7 \pm 4.1,741 \pm 7.3,777.4 \pm 5.5,801.8 \pm 5.2,823.2 \pm$ $5.5,838.5 \pm 6.3$ (Cryogenian), $858.1 \pm 6.5$ (Tonian), $1010 \pm 24$ (Stenian), and $2509 \pm 13$ (Neoarchean) Ma (fig. 11). There is a significant age gap between 1.09 and $1.86 \mathrm{Ga}$, similar to diamictite sample DPK41 in the ET (fig. 11). The dominant zircon population in the Cryogenian is much more abundant than in the diamictite matrix of sample DPK41 (table 1), with fewer amounts of Ediacaran ages and greater amounts of Tonian ages (table 1). Stenian, Siderian, and Neoarchean detrital zircon populations have a similar relative abundance in lonestone DPK38A and the diamictite matrix DPK41 (table 1; fig. 11).

DPK65-Lonestone, from Host Diamictite Sample DPK71 (CT). One hundred sixteen analyses were conducted on 93 zircon grains (table S3). Six analyses are more than $5 \%$ discordant, and the dates of the 110 concordant analyses range from 524.3 to $2789 \mathrm{Ma}$, as shown on a Tera-Wasserburg diagram (fig. 15A). The analyzed zircons are long to short prismatic, subrounded/rounded, light beige to beige and rarely pink, and transparent/semitransparent, and the grain sizes range from 45 to $140 \mu \mathrm{m}$. Oscillatory zoning is common in the outer rim of the zircons, and core parts mostly have complex zoning (fig. S1C). The Th/U ratios of the analyzed concor- dant ages range from 0.06 to 2.08. Just for this sample, analyses were targeted on both the outer rims and the cores to determine the maximum depositional age of the pebbles as well as its provenance. The youngest ages obtained from two analyses yield a concordia age of $528.2 \pm 4.5 \mathrm{Ma}(\mathrm{MSWD}=0.64)$, indicating that the sedimentation age is younger than the Early Cambrian (fig. 15B). This age is, within error, identical to the youngest age obtained from lonestone sample DPK38A (530.8 $\pm 5.2 \mathrm{Ma})$. The age spectrum of the detrital zircons is dominantly Neoproterozoic, with Ediacaran, Cryogenian, and Tonian ages, with lesser amounts of Mesoproterozoic, Paleoproterozoic, and Neoarchean ages (table 1; fig. 11). Significant histogram age peaks are observed at $560.5 \pm 3.6,580.8 \pm 2.9$, and $622.7 \pm 3.2 \mathrm{Ma}$ in the Ediacaran; $756 \pm 5.2$ and $780.5 \pm 3.9 \mathrm{Ma}$ in the Cryogenian; $901.0 \pm 6.1 \mathrm{Ma}$ in the Tonian; $2069 \pm 20 \mathrm{Ma}$ in the Rhyacian; and $2493 \pm 13 \mathrm{Ma}$ in the Siderian (fig. 11). There is a long gap in the zircon ages between 1.05 and $1.71 \mathrm{Ga}$ except one analysis at $1.29 \mathrm{Ga}$ and $1.05-1.98 \mathrm{Ma}$ in the host diamictite sample (DPK71; fig. 11). There is a higher percentage of Ediacaran zircons in this pebble than in its host diamictite sample DPK71, whereas Cryogenian and Tonian ages are less abundant, with equal 


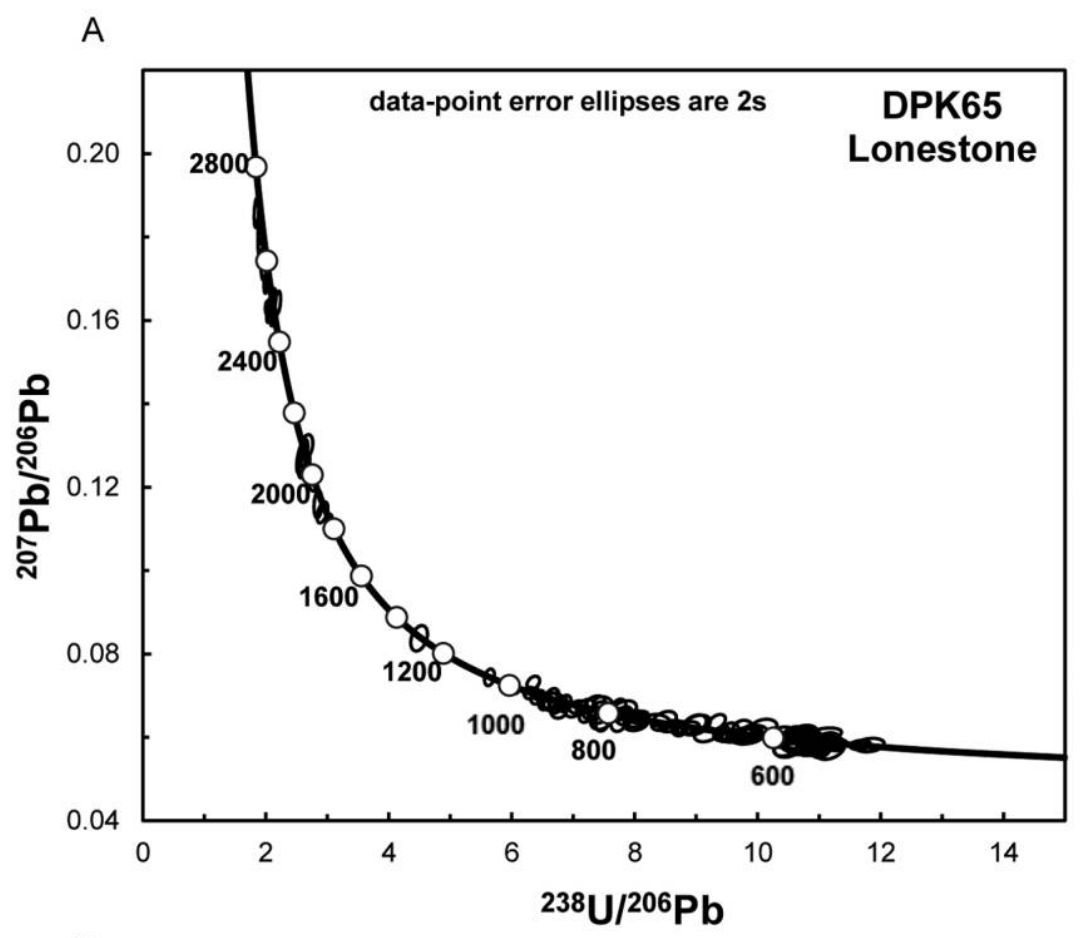

B

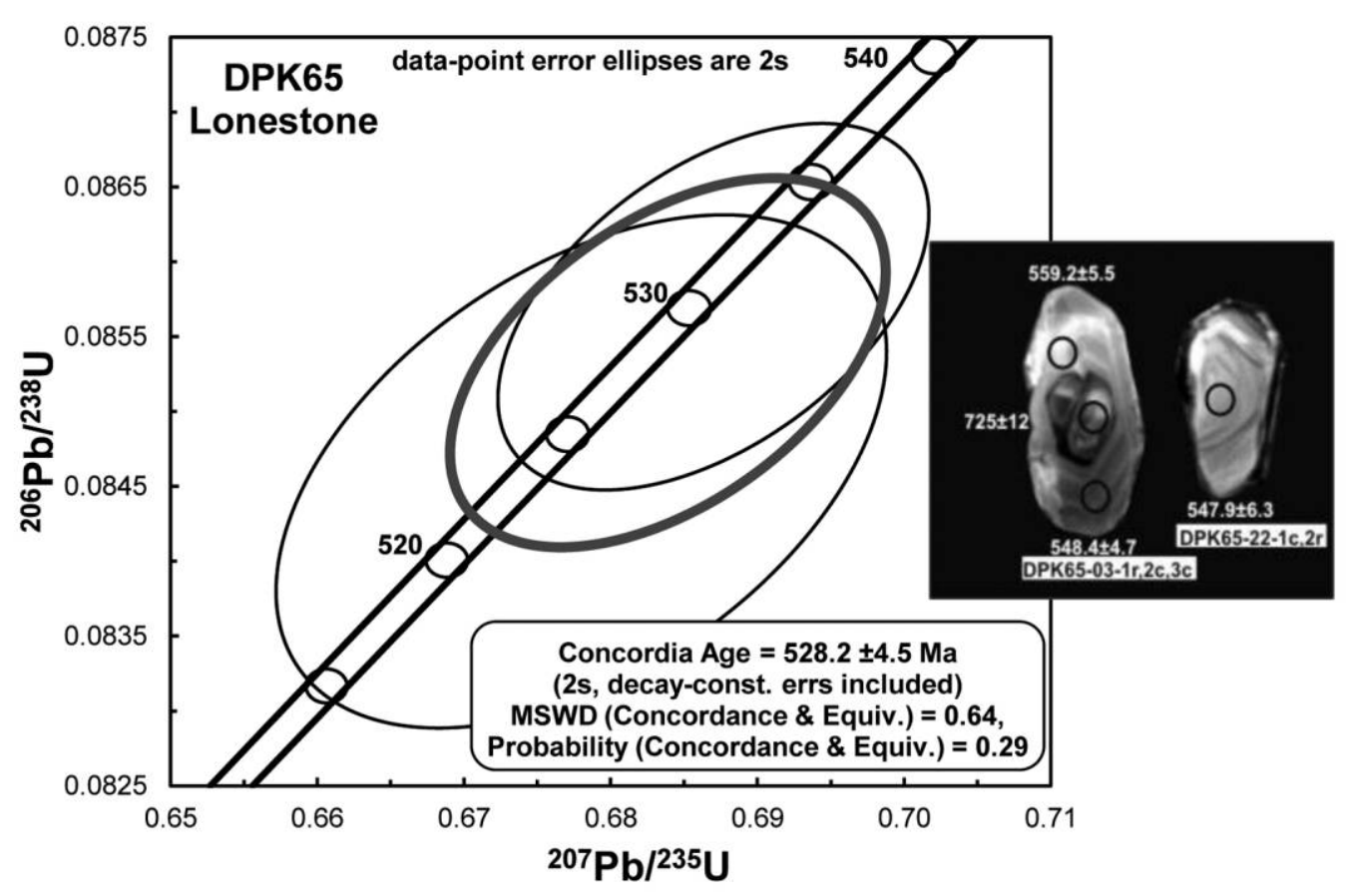

Figure 15. A, Tera-Wasserburg diagram for zircon analyses of lonestone sample DPK65. B, Concordia diagram for the youngest analyses from sample DPK65 and cathodoluminescence images of the youngest ages.

amounts of Siderian and Neoproterozoic age zircons (table 1). The age of the oldest inherited zircon from granitic pebble sample DPK72 collected from the same location was $810 \pm 18 \mathrm{Ma}$, which is close to significant Cryogenian ages of zircons from this sedimentary rock pebble and its host diamictite sample (DPK71), which will be discussed below. 


\section{Discussion and Comments}

Petrogenetic Characteristics of the Granitic Pebbles. Six granitic pebbles (one from the CT and five from the ET) found in the lower and middle parts of the diamictite successions indicate that they were derived from Neoproterozoic granitoid outcrops and then glacially transported and deposited in the TAP during the Hirnantian glaciation event. The inherited zircon populations in the granitic pebbles (except DPK27) indicate that these may have been derived from near-juvenile crustal sources between 780 and 1050 Ma. Sample DPK27 has a crystallization age of $576.7 \pm 5.7 \mathrm{Ma}$ and has a large range of pre-Neoproterozoic xenocrysts, implying that the granitic magma incorporated zircons sourced from pre-Pan-African basement rocks.

The geochemical and petrogenetic features of the individual granitic pebbles are used to determine their original source areas prior to glacial transportation and deposition during Late Ordovician time. Geochemical data for the granitic pebble samples are presented in table 2 .

Multielement diagrams show that samples DPK72, DPK17A, and DPK44 are more enriched in light REEs (LREEs) than in middle REEs (MREEs) and heavy REEs (HREEs; fig. 16). Sample DPK72 is more depleted in HREEs than DPK17A and DPK44 and displays negative anomalies for $\mathrm{Nb}$ and $\mathrm{Ti}$ (fig. 16A, $16 B$ ). In a normal mid-ocean ridge basalt (N-MORB)normalized multielemental diagram, samples DPK27, DPK30, and DPK46 are more depleted in REEs than the other samples, but the HREEs of DPK27 are higher than those of DPK30 and DPK46 (fig. 16B). Similar trends in REE patterns of the granitic pebbles are seen in figure 16B. The N-MORB-normalized LREE elemental patterns of DPK17A, DPK44, and DPK72 show enrichment with slightly negative anomalies of Eu, whereas MREEs and HREEs are similar to N-MORB trends. The exception is sample DPK72, which is relatively depleted in HREEs (fig. 16B). The LREE trends of samples DPK27, DPK30, and DPK46 display a slight enrichment relative to HREEs except for sample DPK27, which is more enriched in HREEs than in LREEs (fig. 16B). The Th, Nb, and $\mathrm{U}$ contents of the granitic pebbles are higher with respect to N-MORB and enriched MORB (E-MORB) sources, with values increasing in the order of DPK30 to $-46,-27,-17 \mathrm{~A},-44$, and -72 (fig. $16 \mathrm{C}$ ). The N-MORBnormalized trends for the granitic pebbles generally indicate mafic sources rather than felsic, but complex U-Pb zircon inheritance patterns imply that they might have been partly assimilated with the older sources.
On a La-Yb diagram, DPK30, DPK46, and DPK27 have very low values correlating with crustal source, but DPK17A and DPK72 display limited crustal inheritance (fig. 16D). On Th/Yb-Nb/Yb diagrams of Pearce (1983), the studied granitic pebbles display deep crustal recycling (source enrichment), more enriched than N-MORB and E-MORB. On Nb-Y and Ta-Yb diagrams of Pearce et al. (1984), all of the studied granitic pebbles plot in the volcanic arc granites field (fig. 16E, 16F), but DPK17A, DPK27, DPK44, and DPK72 are also within the range of the A-type granitic rocks in the Nb-Y diagram (fig. 16E). They plot in the A2-type source that is derived from fractionating or partly melted lower continental crust or arc-type sources on the $\mathrm{Nb}$-Y-Ce diagram of Eby (1992; fig. 16G). On N-MORB- and lower crust (LC)normalized HREE and REE diagrams (fig. 16A, 16H), the source characteristics of samples DPK30 and DPK46 are more depleted in high field strength elements (HFSEs) and REEs than samples DPK17A, DPK27, DPK44, and DPK72. The total REE contents of samples DPK30 and DPK46 are also much lower than the other samples on N-MORB- and LC-normalized multielement diagrams (fig. 16A, $16 H$; table 2). The LILE and LREE enrichment in samples DPK17A, DPK44, and DPK72 is typical for crustal inheritance with moderate levels of fractionation. However, they do not show unequivocal enrichment signatures in a LC-normalized multielement diagram (fig. 16H). These geochemical patterns, combined with the tectonic discrimination diagrams, show that DPK17A, DPK30, and DPK46 might have been derived from island-arc-type source that was more depleted than MORB. Given the contents of the HFSEs and REEs, the protoliths of samples DPK27, DPK44, and DPK72 might have been derived from A-type (A2) source that was generated by partial melting of the crustal and/or arc-type sources.

Provenance of the Granitic Pebbles. The $964.6 \pm$ 4.6 Ma crystallization age of the granitic pebble sample DPK46 in the Hirnantian glacio-marine succession of the ET is the oldest magmatic age determined from this sample set. The Late Neoproterozoic ages in the Cadomian basement of Turkey range from 540 to $590 \mathrm{Ma}$ (e.g., Gürsu 2016), representing magmatic product of the continental arc and postcollisional magmatic activity. No older ages (>590 Ma) have yet been determined in the basement rocks of Turkey.

All granitic pebbles except DPK27 have no preStenian inherited zircons and are interpreted to be derived from juvenile, ca. 0.78-0.90 Ga crustal sources due to their simple age inheritance patterns. 
Table 2. Geochemical Analyses of the Granitic Pebbles

\begin{tabular}{|c|c|c|c|c|c|c|}
\hline & $\begin{array}{c}\text { DPK17A, } \\
\text { metagranite }\end{array}$ & $\begin{array}{l}\text { DPK27, granite- } \\
\text { protomylonite }\end{array}$ & $\begin{array}{l}\text { DPK30, Q- } \\
\text { monzogranite }\end{array}$ & $\begin{array}{c}\text { DPK44, } \\
\text { monzogranite }\end{array}$ & $\begin{array}{l}\text { DPK46, } \\
\text { metagranite }\end{array}$ & $\begin{array}{c}\text { DPK } 72, \\
\text { metagranite }\end{array}$ \\
\hline \multicolumn{7}{|c|}{ Major elements: } \\
\hline $\mathrm{SiO}_{2}$ & 75.96 & 73.39 & 72.03 & 66.79 & 68.47 & 79.33 \\
\hline $\mathrm{Al}_{2} \mathrm{O}_{3}$ & 12.82 & 13.47 & 15.07 & 15.85 & 16.13 & 11.88 \\
\hline $\mathrm{Fe}_{2} \mathrm{O}_{3}$ & 2.46 & 2.59 & 2.56 & 5.87 & 4.30 & 1.05 \\
\hline $\mathrm{MgO}$ & .42 & .81 & .66 & 1.13 & .80 & .13 \\
\hline $\mathrm{CaO}$ & .76 & .37 & .52 & .21 & .18 & .27 \\
\hline $\mathrm{Na}_{2} \mathrm{O}$ & 5.61 & 4.46 & 5.13 & 4.95 & 3.58 & 5.80 \\
\hline $\mathrm{K}_{2} \mathrm{O}$ & .47 & 1.64 & 1.31 & 1.32 & 2.01 & .27 \\
\hline $\mathrm{TiO}_{2}$ & .28 & .94 & .55 & .76 & .75 & .17 \\
\hline $\mathrm{P}_{2} \mathrm{O}_{5}$ & .06 & .20 & .12 & .07 & .08 & .05 \\
\hline $\mathrm{MnO}$ & .03 & .03 & .03 & .02 & .07 & .02 \\
\hline $\mathrm{Cr}_{2} \mathrm{O}_{3}$ & .002 & .002 & .002 & .006 & .002 & .002 \\
\hline LOI & 1.00 & 1.90 & 1.90 & 2.80 & 3.50 & .90 \\
\hline Total & 99.86 & 99.83 & 99.85 & 99.81 & 99.85 & 99.89 \\
\hline \multicolumn{7}{|c|}{ Trace elements: } \\
\hline $\mathrm{Ga}$ & 14.4 & 17.1 & 12.1 & 15.0 & 15.3 & 13.2 \\
\hline Hf & 5.8 & 6.1 & 3.4 & 6.4 & 3.0 & 4.0 \\
\hline $\mathrm{Nb}$ & 11.2 & 9.9 & 6.3 & 16.1 & 6.6 & 10.3 \\
\hline $\mathrm{Rb}$ & 15.5 & 40.5 & 42.5 & 34.7 & 56.4 & 14.4 \\
\hline $\mathrm{Sr}$ & 125.1 & 82.6 & 191.8 & 149.8 & 75.3 & 124.7 \\
\hline $\mathrm{Ta}$ & .8 & .7 & .5 & 1.1 & .2 & .9 \\
\hline Th & 5.3 & 6.7 & 3.0 & 9.9 & 4.4 & 15.7 \\
\hline $\mathrm{U}$ & .9 & 1.2 & .6 & 1.5 & .6 & 2.0 \\
\hline V & 8.0 & 31.0 & 48.0 & 73.0 & 77.0 & 11.0 \\
\hline $\mathrm{Zr}$ & 198.5 & 225.8 & 123.2 & 213.6 & 112.1 & 137.4 \\
\hline $\bar{Y}$ & 22.8 & 39.1 & 3.5 & 23.8 & 3.7 & 11.4 \\
\hline $\mathrm{Ti}$ & 1679 & 5635 & 3297 & 4556 & 4496 & 1019 \\
\hline \multicolumn{7}{|l|}{ REEs: } \\
\hline $\mathrm{La}$ & 21.10 & 4.20 & 2.70 & 12.60 & 3.90 & 22.10 \\
\hline $\mathrm{Ce}$ & 49.00 & 8.50 & 4.80 & 31.30 & 9.40 & 49.50 \\
\hline $\operatorname{Pr}$ & 6.13 & .98 & .54 & 3.89 & 1.13 & 5.39 \\
\hline $\mathrm{Nd}$ & 25.50 & 4.30 & 2.50 & 15.40 & 5.00 & 20.00 \\
\hline $\mathrm{Sm}$ & 5.33 & 1.55 & .57 & 3.93 & 1.42 & 4.59 \\
\hline $\mathrm{Eu}$ & 1.36 & .63 & .18 & .72 & .45 & 1.11 \\
\hline $\mathrm{Gd}$ & 4.84 & 4.36 & .75 & 3.77 & 1.77 & 3.65 \\
\hline $\mathrm{Tb}$ & .78 & .94 & .12 & .60 & .22 & .49 \\
\hline Dy & 4.49 & 6.49 & .71 & 3.87 & .81 & 2.59 \\
\hline Ho & .93 & 1.44 & .14 & .85 & .14 & .47 \\
\hline Er & 2.96 & 3.97 & .48 & 2.71 & .41 & 1.33 \\
\hline $\mathrm{Tm}$ & .44 & .62 & .08 & .42 & .05 & .19 \\
\hline $\mathrm{Yb}$ & 3.22 & 3.94 & .56 & 3.18 & .40 & 1.46 \\
\hline $\mathrm{Lu}$ & .51 & .63 & .10 & .48 & .07 & .23 \\
\hline$\sum$ REEs & 126.60 & 42.60 & 14.20 & 83.70 & 25.20 & 113.10 \\
\hline$(\mathrm{La} / \mathrm{Yb})_{\mathrm{N}}$ & 4.70 & .76 & 3.45 & 2.84 & 6.99 & 10.85 \\
\hline$(\mathrm{DyYb})_{\mathrm{N}}$ & 1.83 & .43 & 1.13 & 1.37 & 3.94 & 6.49 \\
\hline$(\mathrm{Gd} / \mathrm{Yb})_{\mathrm{N}}$ & 1.24 & .91 & 1.10 & .98 & 3.66 & 2.06 \\
\hline$(\mathrm{Eu} / \mathrm{Eu})_{\mathrm{N}}$ & .81 & .75 & .86 & .57 & .86 & .83 \\
\hline
\end{tabular}

Note. Normalization is from Sun and McDonough (1989). REE = rare earth element.

A $0.90-1.1 \mathrm{Ma}$ magmatic activity (Kibaran) in the Mozambique Belt was previously reported only from Central Africa (Kroner 2001). But magmatic suites of similar age have been recently documented by Be'eri-Shlevin et al. (2012) and Eyal et al. (2014) in Sinai (Egypt). The latter authors describe the
Agramyia Formation within the Sa'al Metamorphic Complex in Sinai (Egypt; fig. 17A) as being composed of rhyolites as well as subvolcanic and plutonic intrusions that were evolved from the Sa'al island arc between 0.93 and $1.03 \mathrm{Ga}$. The oldest concordia age of their tonalitic gneisses was deter- 
A

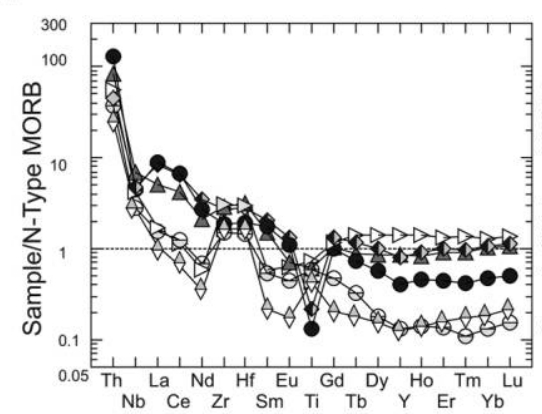

D

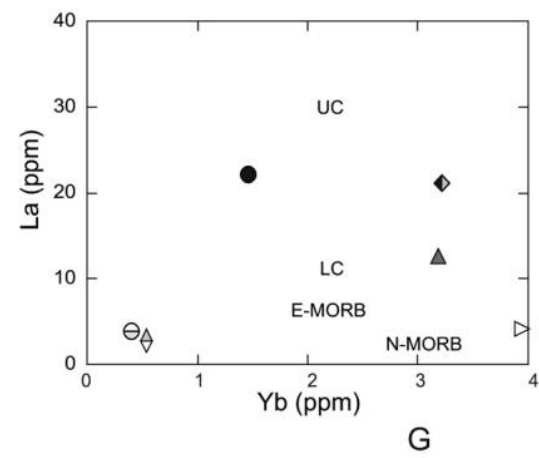

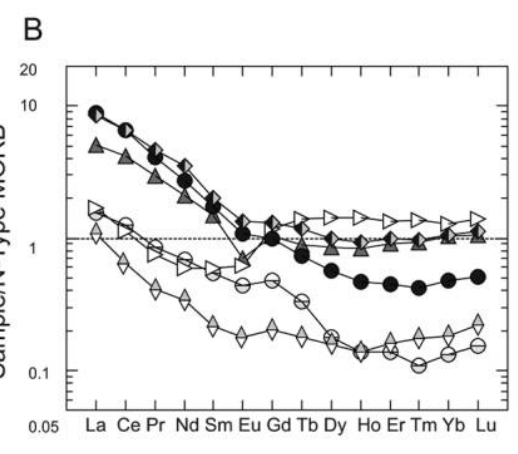

E

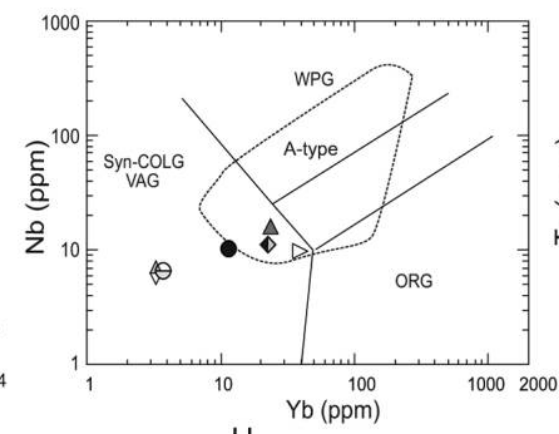

C

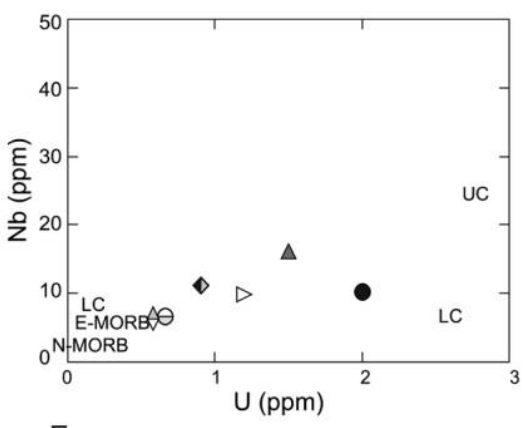

$\mathrm{F}$

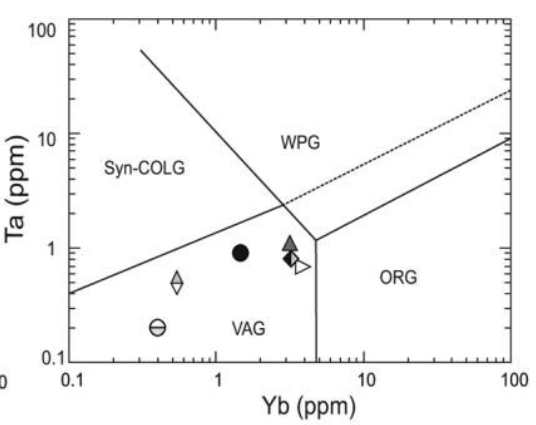

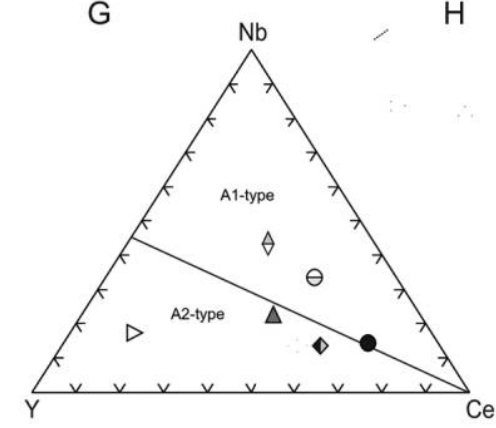

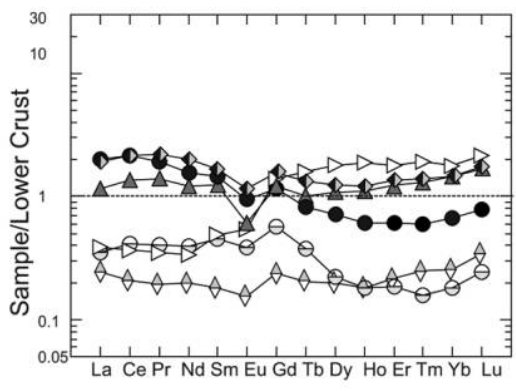

- DPK17A, $\triangleright$ DPK27, $\ominus$ DPK30,

$\ominus$ DPK46, $\triangle$ DPK44, $\bullet$ DPK72

Figure 16. $A, B$, Multielement diagram and rare earth element (REE) patterns of the studied samples (normal mid-ocean ridge basalt [N-MORB] normalization from Sun and McDonough 1989). C, Nb-U variation diagram. $D$, La$\mathrm{Yb}$ variation diagram. E, F, Nb-Yb and Ta-Yb variation diagrams (Pearce et al. 1984). G, Nb-Y-Ce diagram of the studied rocks (after Eby 1992). H, Multielement diagram and REE patterns of the studied samples. A1 type: anorogenic granites (related to ocean island-type sources); A2 type: anorogenic granites (related to average continental crust or arc-type sources). N-MORB and enriched MORB (E-MORB) data are from Sun and McDonough (1989), upper and lower crustal data and normalization are from Taylor and McLennan (1995), and A-type classification is from Eby (1992). LC = lower crust; ORG = ocean ridge granitoids; Syn-COLG = syncollision granitoids; UC = upper crust; VAG $=$ volcanic arc granitoids; $\mathrm{WPG}=$ within-plate granitoids.

mined as $977 \pm 7.0 \mathrm{Ma}$ (Eyal et al. 2014), which is similar to the age of the subrounded metagranitic pebble (DPK46) found in the Hirnantian glacio-marine successions in the ET. The volcanic arc-related geochemical features of the studied pebble are also in accordance with these oldest arc-related igneous suites formed in the Sinai Peninsula (Egypt).

The other important Cryogenian-Tonian granitic magmatism between 870 and $740 \mathrm{Ma}$ observed in the
Sinai Peninsula is located in the Feiran-Solaf Metamorphic Complex (El-Shafei and Kusky 2003; Abu El-Enen and Whitehouse 2013; Eyal et al. 2014; fig. 17A). The oldest granitic magmatism there was determined as $804.8 \pm 4.7 \mathrm{Ma}$ (El-Shafei and Kusky 2003), $785.0 \pm 7.0 \mathrm{Ma}$ (Eyal et al. 2014), and $792 \pm$ 7.0 Ma (Abu El-Enen and Whitehouse 2013) and was evaluated as intrusives of the Elat-Feiran island arc system. The crystallization age of the subrounded 


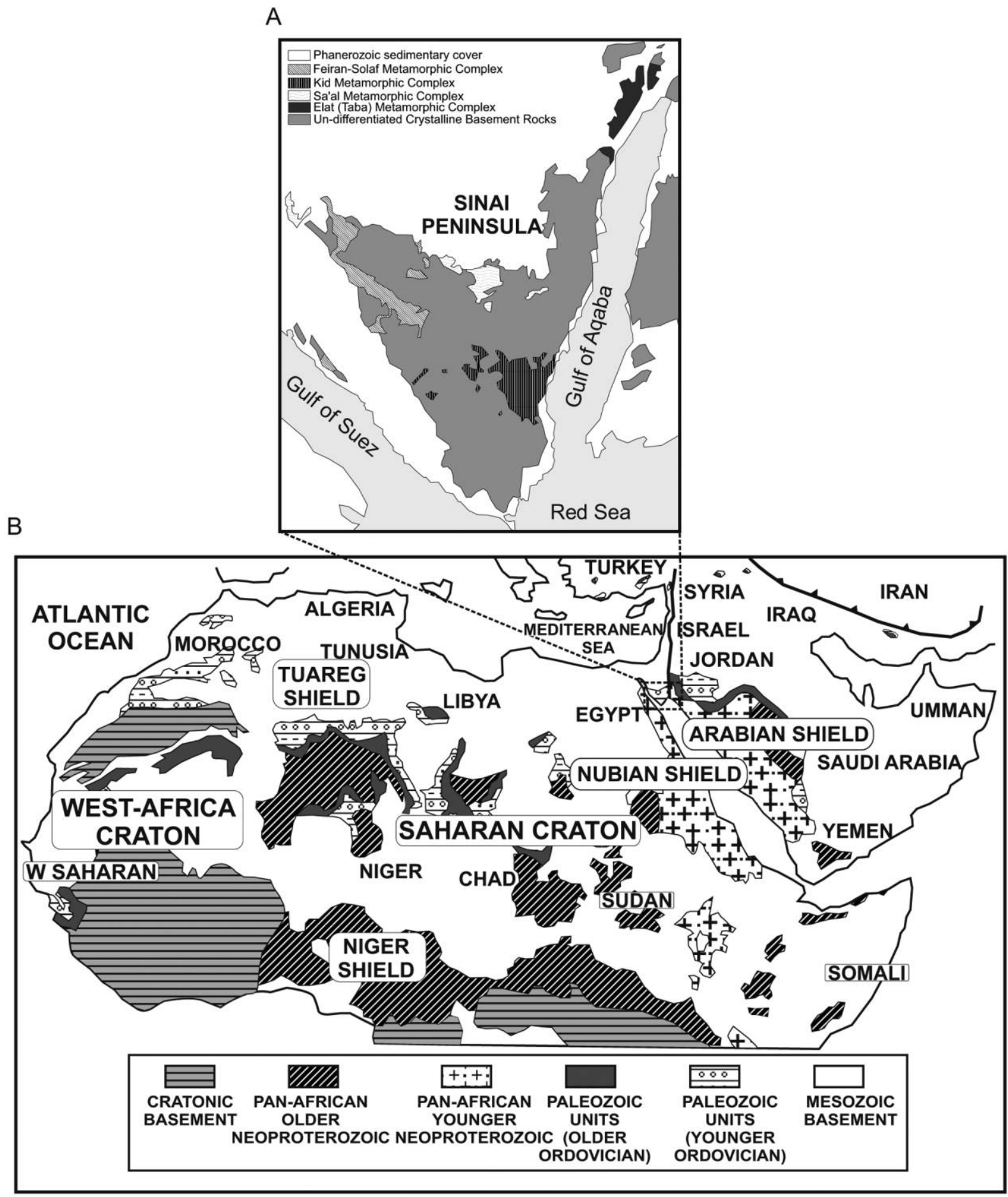

Figure 17. A, Distributions of the Neoproterozoic metamorphic complexes in Sinai (Egypt). B, Paleogeographic distribution of Cambrian-Ordovician units in northern Africa and Arabia (after Abdelsalam et al. 2002; Avigad et al. 2003, 2005, 2012; Meert and Liebermann 2008; von Raumer and Stampfli 2008; Meinhold et al. 2011). A color version of this figure is available online.

metagranitic pebble (DPK17A) in the ET (TufanbeyliKayapınar1 area) is dated as $789.5 \pm 3.7 \mathrm{Ma}$ with an older core yielding $812.1 \pm 1.9 \mathrm{Ma}$, similar to the metagranitic rocks in the Feiran-Solaf Metamorphic
Complex in Wadi Umm Takha, and it might be derived from the Elat (Taba)-Feiran arc system during the Late Cryogenian period. This correlation is further geochemically supported by the arc-related 
geochemical signatures of the equivalent rocks that are enriched in LREEs and HFSEs compared with the typical island-arc magmatic suites in the FeiranSolaf Metamorphic Complex (details in Abu El-Enen and Whitehouse 2013), as in sample DPK17A.

The Elat (Taba) Metamorphic Complex is an isolated metamorphic complex located near the boundary of Egypt and Israel in the northeastern part of the Sinai Peninsula (fig. 17A). It is composed of peliticpsammitic schists, migmatites, and amphibolites, cut by various granitic intrusions (e.g., Eyal et al. 2014) that were subsequently metamorphosed to form granitic gneisses. The crystallization ages of their protoliths were previously determined as $735.0 \pm$ $9 \mathrm{Ma}$ by Kolodner (2007) and were assigned to the youngest intrusive products of the Elat (Taba)-Feiran arc system between 790 and $730 \mathrm{Ma}$. Arc-type metatonalites $(719 \pm 10,725 \pm 9.0 \mathrm{Ma})$ and metagranodioritic rocks (744 $\pm 10 \mathrm{Ma})$ of similar ages have been recently documented from the Wadi Beitan area in the Southeastern Desert of Egypt by Ali et al. (2015). Because of their tonalitic-granodioritic features and pronounced continental crustal signatures, the $717.5 \pm 8.0 \mathrm{Ma}$ crystallization age of the subrounded metagranitic pebble (DPK30) in the Feke (Ceralan) section of the Hirnantian glacio-marine succession can be geochronologically correlated with the youngest metagranitic rocks in the Elat (Taba) Metamorphic Complex and might have evolved together in the Elat (Taba) island arc tectonic environment ca. $725 \mathrm{Ma}$. This is also supported by its I-type source characteristics and arc-type geochemical signatures.

The late-stage Pan-African granitic intrusions (monzodiorite, syenogranite, and alkali granite) representing alkaline/peralkaline magmatism between 686 and $590 \mathrm{Ma}$ in the Hijaz (Jabal Sayad Complex) and Asir terranes of Saudi Arabia (Cooper et al. 1979; Duyverman et al. 1982; Johnson et al. 2001; Moghazi et al. 2015), between 645 and $615 \mathrm{Ma}$ in the Afif terrane of Saudi Arabia (Cole and Hedge 1986), and between 578 and $602 \mathrm{Ma}$ in the Sinai Peninsula of Egypt (Kröner et al. 1990; Kolodner et al. 2006; Ali et al. 2009; Be'eri Shlevin et al. 2009; Moreno et al. 2012; Abu El-Enen and Whitehouse 2013) have been documented in detail in the ANS. A-type monzogranitic intrusions between $578 \pm 8.0 \mathrm{Ma}$ (Iqna) and 582.0 \pm 6.0 Ma (Karetina Ring Complex) of the central and northwestern part of the Sinai Peninsula (Be'eri-Shlevin 2009) can be geochronologically correlated with the monzogranitic pebble DPK44 $(576.5 \pm 5.3 \mathrm{Ma})$ observed within the diamictites in the ET (Feke-Gökmenler). This correlation is also geochemically supported by A-type (A2) characteristics of sample DPK44. The crystallization ages of the alkaline/peralkaline granitic intrusions in the Katerina Pluton (KP) within the Katerina Ring Complex in central Sinai Peninsula, the North Eastern Desert (Gattar, Abu Harba, Missikat), and the Jabal Sayad Complex (Hijaz) were determined to be $596 \pm 6.0 \mathrm{Ma}$ (KP), $593 \pm 2 \mathrm{Ma}(\mathrm{KP}), 605 \pm 3.0 \mathrm{Ma}$ (Gattar), $595 \pm$ 3.0 Ma (Abu Harba), $597 \pm 7.0 \mathrm{Ma}$ (Missikat), and $593 \pm 16 \mathrm{Ma}$ (Katzir et al. 2007; Moussa et al. 2008; Moreno et al. 2012; Moghazi et al. 2015; Ali et al. 2016). The geochemical patterns of DPK 72 have greater similarities with the alkaline granites formed in the Katerina Ring Complex (Katzir et al. 2007; Moreno et al. 2014) and the North Eastern Desert (Moussa et al. 2008; Ali et al. 2016) than they do with those formed in the Jabal Sayad Complex in Hijaz (Moghazi et al. 2015). Lack of preTonian inherited zircons in the sample and A-type geochemical features of the studied granitic pebble also support the idea that it might be derived from mantle or mafic lower-crustal sources, as in the equivalent intrusions in the KP (Katzir et al. 2007; Moreno et al. 2012) and the North Eastern Desert (Moussa et al. 2008). The newly published $\mathrm{Hf} / \mathrm{Lu}$ isotopic study (Ali et al. 2016) of the alkali granitic rocks in the North Eastern Desert (Abu Harba, Gattar, and A. Missikat) support that A-type granites were generated from juvenile Neoproterozoic mantle source and then were assimilated with just Neoproterozoic materials, as in sample DPK72. The penetrative deformation and metamorphism in the Sinai Peninsula had mainly ceased between 625 and $635 \mathrm{Ma}$ (Be'eri-Shlevin et al. 2009), but important mega-shear zones, such as the Nugrus/Najd shear zones in the Nubian part of the ANS and the Qazaz-Ajiaj shear zone in the Arabian part of the ANS, were documented for the southern part of the ANS during the time span 630-570 Ma (e.g., Johnson et al. 2011; Meyer et al. 2014; Hassan et al. 2016). The crystallization age of the foliated/undeformed granites from the margin of the Ajjaj shear zone was determined as $575 \pm 10$ and $581 \pm 4.0 \mathrm{Ma}$ by Kennedy et al. (2011) and Hassan et al. (2016), respectively. The Qazaz-Ajiaj shear zone continuously extends to the central and southern parts of the Eastern Desert of Egypt to form the Nugrus/Najd shear zones (Sultan et al. 1990). Polydeformed/polymetamorphosed postorogenic A-type granitic rocks intruded the Neoproterozoic basement rocks there and underwent ductile penetrative deformations along these mega-shear zones between 610 and $550 \mathrm{Ma}$ (e.g., El-Sayed et al. 2007; Johnson et al. 2011; Abu El-Enen et al. 2016). The highly deformed/cataclastic granitic rocks of the same age in the Nugrus/Najd shear zone are documented from the Nakhil granitoids $(578 \pm 15 \mathrm{Ma})$ in the central Egyptian desert (Sultan et al. 1990) and 
the northern Egyptian desert. The highly deformed granitic pebble $(\mathrm{DPK} 27 ; 576.7 \pm 5.7 \mathrm{Ma})$ in the ET showing A-type affinity might have been derived from Nahkil or younger granitoids in the Eastern Desert area of the Nubian part of the ANS rather than from less deformed/undeformed equivalents in the Qazaz-Aijaj shear zone in the Arabian Shield and then deformed just after its genesis along the Nugrus shear zone.

In summary, the dated rounded/subrounded island arc and A-type granitic pebbles observed in the Hirnantian glacial successions of the central and eastern TAP in southern Turkey range from 964 to $576 \mathrm{Ma}$ in age and are interpreted to have been derived from plutons formed in the Sinai Peninsula and the northeastern part of the Nubian Shield.

Provenance of Detrital Zircons in the Matrix of the Dropstone and Lonestone Pebbles. The Late Ordovician (Hirnantian) paleogeography with ice flow directions on the Gondwana supercontinent as proposed by Torsvik and Cocks (2011) is shown in figure 1 . The ice flow directions in the paleographic reconstruction for Turkey (previously reported by Monod et al. [2003] and Ghienne et al. [2010]) show that the ice sheets are interpreted to have drifted from Egypt (Sinai) to Jordan, Israel, and Turkey. The ice flow direction in combination with the U-Pb zircon geochronology can be an indication of possible source areas for the CT, the ET, and the SAAB. Monod et al. (2003) and Ghienne et al. (2010) proposed Egypt and Libya as source areas of the glacio-marine successions in the Taurides and the SAAB. The finding of the late Tonian subrounded Sinai-origin granitic pebble within the Hirnantian glacio-marine successions in the TAP suggests that there might have been no hidden Tonian basement in the TAP, as previously proposed by Abbo et al. (2015) and Avigad et al. (2016). The newly determined Tonian U-Pb magmatic ages from the granitic pebbles reveal that it was the Neoproterozoic basement rocks in the ANS that were eroded and transported by the Late Ordovician glaciations. These data also fit well with the paleogeographic reconstruction proposed by Torsvik and Cocks (2011; fig. 1).

Kernel and probability density plots of the studied diamictites and lonestones are presented in figure 11. The age spectra of the zircon ages of the sample locations present general trends with some differences between samples and regions. The percentages of zircon populations from the diamictite matrices and lonestones are given in table 2 .

To correlate U-Pb age distributions of the glaciomarine successions in the TAP and SAAB with similarities and differences in the age distributions of the potential provenance areas, the nonparametric Kolmogorov-Smirnov (KS) statistical test was used in this study (details in Guynn and Gehrels 2010). The test is used on the distributions of detrital zircon U-Pb age populations to establish whether samples have been sourced from the same region or not (tables 3, 4). Cumulative distribution function (CDF) diagrams of the lonestone pebbles, diamictites, and their possible source areas are produced from the algorithms published at the website http://www.physics .csbsju.edu/stats/KS-test.html.

The two subrounded/well-rounded siliciclastic pebbles (DPK65 in the CT and DPK38A in the ET) yield youngest ${ }^{206} \mathrm{~Pb} /{ }^{238} \mathrm{U}$ zircon ages of $528.2 \pm 4.5$ and $530.8 \pm 5.2 \mathrm{Ma}$, respectively, and contain four main older populations: Neoproterozoic, Mesoproterozoic, Paleoproterozoic, and Neoarchean (table 1). A comparison of detrital data on the two lonestones shows some similarities in that most of the detrital grains are Neoproterozoic (DPK38A, 88.5\%; DPK65, 77.3\%). There are some similarities in the age distribution of the pre-Neoproterozoic grains, but their relative proportions differ (table 1; fig. 11). The sources of the two lonestone pebbles are interpreted to have derived from similar Neoproterozoic sources, but they include varying amounts of older material, presented in probability density plots (fig. 11). The KS test performed on the lonestone pebble samples DPK65 (CT) and DPK38 (ET) indicates that U-Pb ages of the two populations are not significantly different $(P=0.095$; table 3). The two samples have similar youngest detrital age zircons comparable to the diamictite sample and can be considered to be coeval with a post-Early Cambrian depositional age. They are statistically correlated with similar areas in the northern margin of Gondwana and Arabia (fig. 18). The KS test data on samples DPK65 and DPK38A, their potential source areas in North Africa and the ANS, and their CDF patterns are given in table 3 and figure $18 A$ and $18 B$.

The youngest detrital zircon ages $(<550 \mathrm{Ma})$ in both lonestones and diamictites imply the magmatic activity of the late-stage phase of the Cadomian orogeny of the Pan-African cycle. Cambrian-Ordovician sandstones constitute key stratigraphic horizons along the northern margin of the Gondwana extending from the ANS to the Saharan and West African craton (e.g., Abdelsalam et al. 2002; von Raumer and Stampfli 2008; Meinhold et al. 2011; Avigad et al. 2003, 2005, 2012) and also crop out in the European margin of the peri-Gondwanan areas (fig. 17B). In the sandstones of the ANS, Neoproterozoic zircon ages are dominant, with lower amounts of older crustal-derived detrital zircons (Middle/Early Paleoproterozoic, Neoarchean; e.g., Avigad et al. 2003, 2005, 2012; Kolodner et al. 2006; Meinhold et al. 2011). The early Ediacaran, middle Cryogenian, and early Tonian magmatic ages of the granitic pebbles observed within 


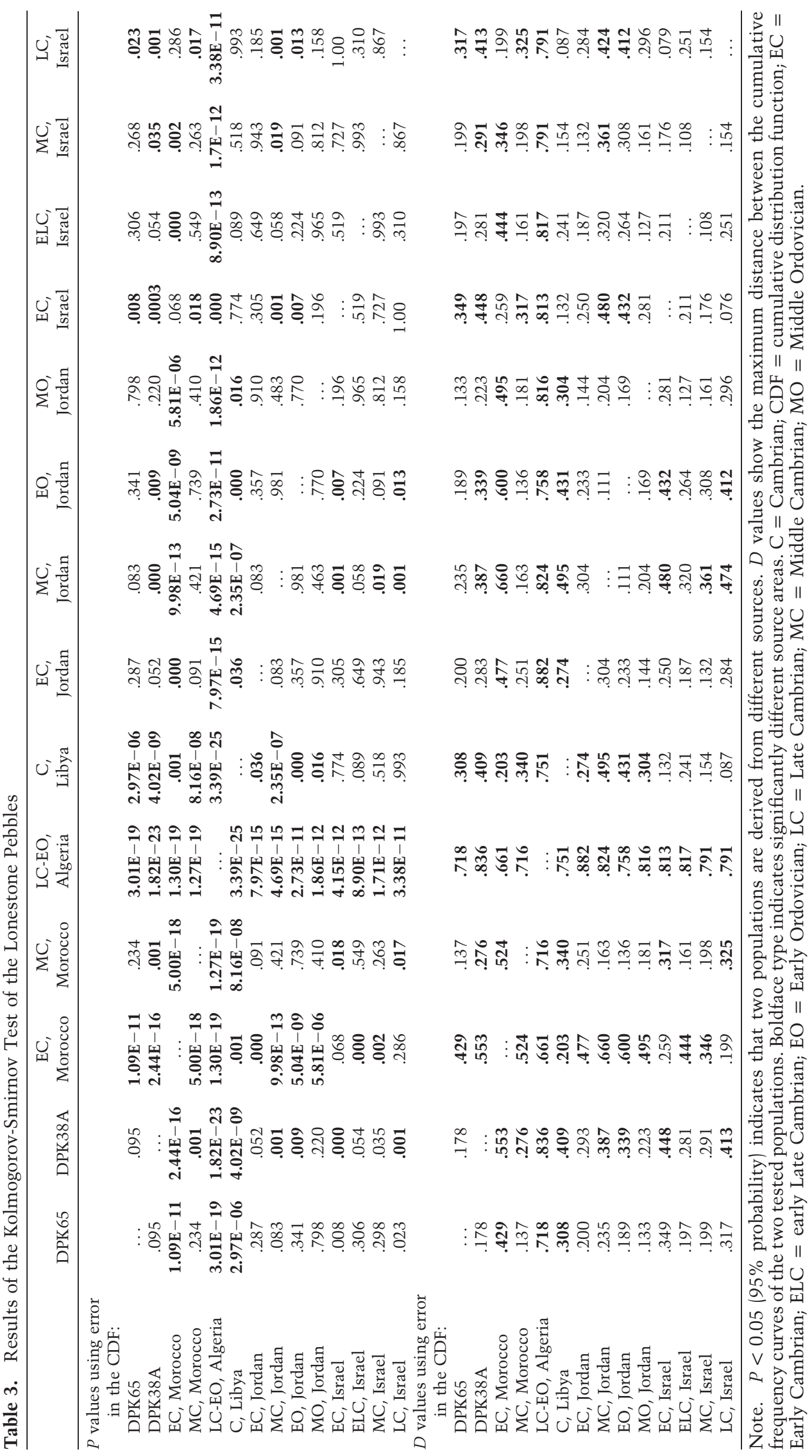

This content downloaded from 129.237.045.171 on November 09, 2018 13:39:58 PM 
Table 4. Results of the Kolmogorov-Smirnov Test of the Diamictites

\begin{tabular}{lccc}
\hline & DPK41 & DPK71 & BY2 \\
\hline$P$ values using error in the CDF: & & & \\
DPK41 & $\ldots$ & .012 & .048 \\
DPK71 & .012 & $\ldots$ & .087 \\
BY2 & .048 & .087 & $\ldots$ \\
$D$ values using error in the CDF: & & & \\
DPK41 & $\ldots$ & .211 & .193 \\
DPK71 & .211 & $\ldots$ & .170 \\
BY2 & .193 & .170 & $\ldots$ \\
\hline
\end{tabular}

Note. $\quad P<0.05$ (95\% probability) indicates that two populations are derived from different sources. $D$ values show the maximum distance between the cumulative frequency curves of the populations. $\mathrm{CDF}=$ cumulative distribution function.

diamictite matrices imply that magmatic/sedimentary pebbles were mainly eroded and transported from the northern margin of Gondwana and/or Arabia, not from peri-Gondwanan parts of the European margin. The predominance of Ediacaran and Cryogenian zircon populations in both lonestone pebbles (this study), with less amounts of Tonian zircons, indicate that their derivation was mainly from EdiacaranCryogenian igneous basements of the ANS (figs. 11, 19).

The zircon populations of the lonestone samples on the CDF and kernel density plots do not match the patterns of North Africa siliciclastics except for Middle Cambrian siliciclastic rocks in Morocco (figs. 18A, 18B, 19). However, the Middle Cambrian sequence in Morocco has a variety of Mesoarchean and Paleoarchean zircon populations that are absent in the studied lonestone pebbles (fig. 19). On the other hand, postcollisional alkaline/calk-alkaline magmatic rocks between 700 and $540 \mathrm{Ma}$, island arc magmatic suites between 900 and $735 \mathrm{Ma}$, and arctype intrusions between 1100 and $900 \mathrm{Ma}$ are widespread in the ANS (e.g., Fritz et al. 2010; Johnson et al. 2011; Be'eri-Shlavin et al. 2012; Eyal et al. 2014), and $P$ values for these areas are higher than 0.05 (table 3). The detrital zircon populations of sample DPK65 on the kernel density diagram with significant peaks at 575, 780, and $900 \mathrm{Ma}$ are consistent with their derivation from juvenile igneous activity in the ANS (Be'eri-Shlavin et al. 2012; Abu El-Enen and Whitehouse 2013; Eyal et al. 2014; fig. 19). The KS test results indicate that the U-Pb age distributions of sample DPK65 match well with Early Cambrian to Early Ordovician siliciclastic rocks, especially the Early Cambrian Salib Formation (Jordan; $P>0.287$ ), the Early/Late Cambrian Timna Formation (Israel; $P>0.306)$, the Middle Cambrian Shehoret Formation (Israel; $P>0.298$ ), the Early Ordovician UmmSham Formation (Jordan; $P>0.341$ ), and the Middle
Ordovician Dubaydid Formation (Jordan; $P>0.798$; Kolodner et al. 2006). However, the significant age peaks of sample DPK65 seem to fit better with the Middle Cambrian Skeolet Formation in Israel than the other Cambro-Ordovician units in Israel and Jordan (fig. 19). This source area is also a good fit according to the data of the KS test $(P=0.268)$ and the CDF diagrams (table 3, fig. 18A).

Well-rounded lonestone sample DPK38A has significant peaks at 625 and $813 \mathrm{Ma}$ with late Statherian and late Neoarchean inherited zircon populations and correlates well with the Middle Ordovician Dubaydib Formation (Jordan; $P=0.220$ ) on the CDF and kernel density diagrams (table 3; figs. 18B, 19). The dominant detrital zircon populations in the Cryogenian in the sample may indicate that it might have been transported from pre-Cambrian units of the ANS, especially from the Elat (Taba)-Feiran island arc.

Provenance of the Diamictites. The three diamictite samples from the CT (DPK71), the ET (DPK41), and the SAAB (BY2) show different abundances of detrital zircon populations, with Neoproterozoic, Late Mesoproterozoic, Early Paleoproterozoic, and Neoarchean populations with distinctive peaks between 1020 and $610 \mathrm{Ma}$ and between 2600 and $1700 \mathrm{Ma}$ on kernel density diagrams (figs. 11, 19). The KS test shows that the U-Pb zircon age distributions of the DPK71 and BY2 have significantly different characteristics than sample DPK41 based on their $P$ values (table 4). The highest $P$ value observed is between samples DPK71 and BY2 $(P=0.087)$, which is interpreted to indicate that they are derived from similar source areas (table 4). The detrital zircon populations of the diamictite samples on the CDF diagram display different patterns that cannot present a direct correlation between samples DPK41 (ET), DPK 71 $(\mathrm{ET})$, and BY2 (SAAB; fig. 18C). In the diamictite samples, Ediacaran and Cryogenian detrital zircon populations are most dominant with $65.6 \%$ and $76.2 \%$ of the total analyzed detrital zircons. They are followed by Tonian, Stenian, Ectasian, Orosirian, Rhyacian, Siderian, and Neoarchean populations (table 1). The detrital zircon populations in sample DPK41 show a broad range of dates between ca. 650 and $590 \mathrm{Ma}$, with the most abundant age peak ca. $614 \mathrm{Ma}$, followed by peaks at $798,863,1007$, and $2478 \mathrm{Ma}$ (fig. 20). In sample DPK71, Cryogenian zircons are more abundant than Ediacaran zircons, with significant peaks at $639,805,978,2050$, and $2488 \mathrm{Ma}$ (fig. 20). In sample BY2, there is a relatively narrow distribution of detrital zircon ages that have major significant peaks at 663 and $1013 \mathrm{Ma}$, with minor peaks at 1977, 2096, and $2611 \mathrm{Ma}$ (fig. 20). These major peaks in sample BY2 may indicate that 


\section{A}

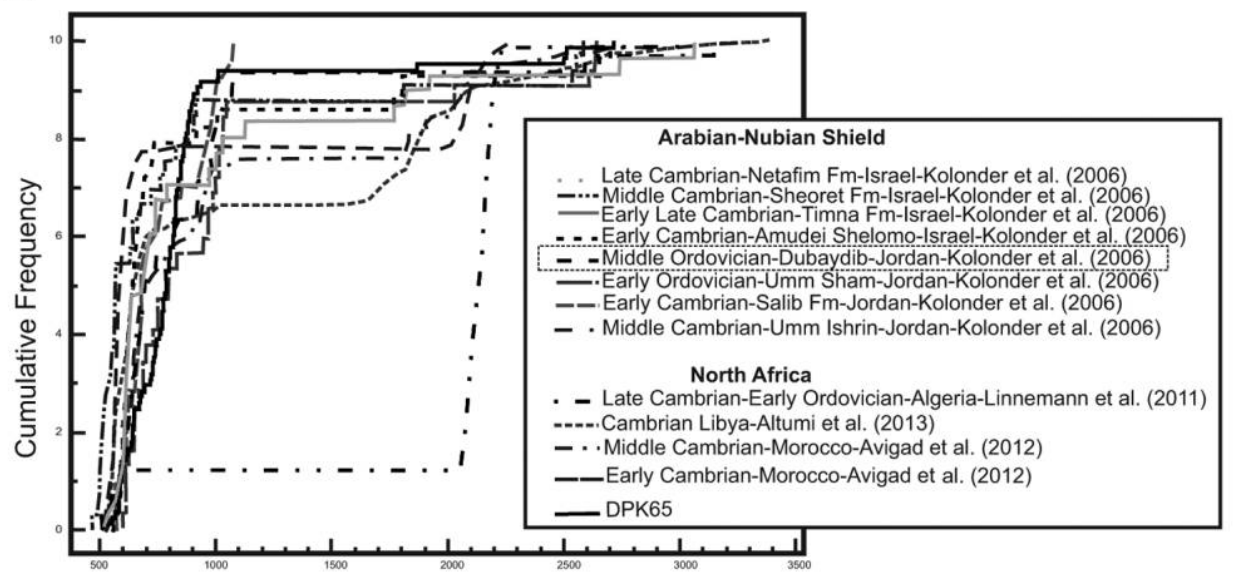

$\mathrm{B}$

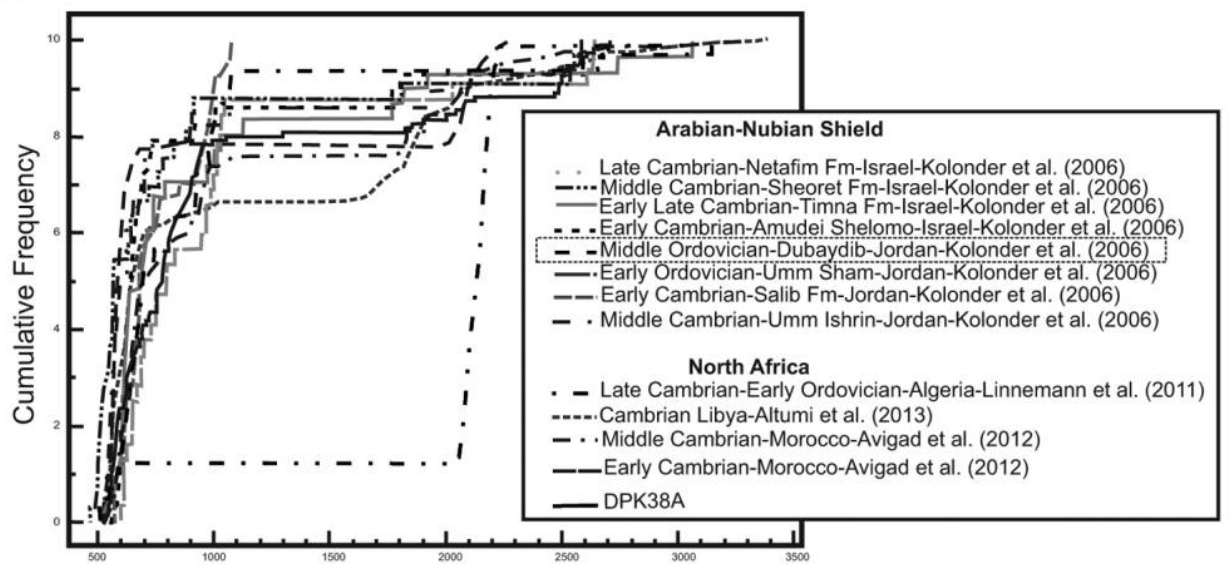

C

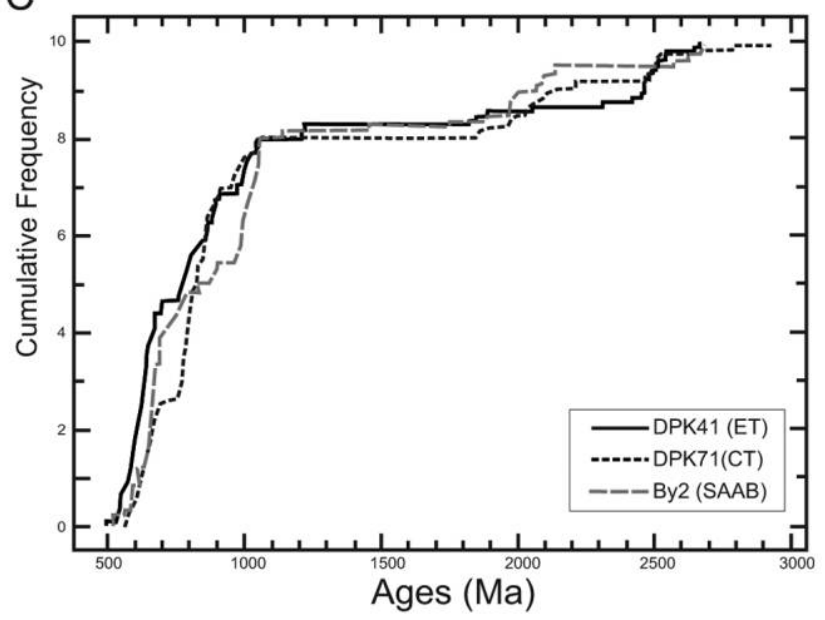

Figure 18. $A, B$, Cumulative distribution function (CDF) diagrams of the lonestone samples (DPK65, DPK38A) and their potential source areas in North Africa and the Arabian-Nubian Shield. C, CDF diagram of the diamictite samples (DPK41, DPK71, BY2). CT = Central Taurides; ET $=$ Eastern Taurides; SAAB $=$ Southeast Anatolian Autochthon Belt. A color version of this figure is available online.

source areas of the glacio-marine succession in the SAAB are somewhat different from those for the CT and ET of the TAP. All of the diamictite samples have pronounced Early Neoproterozoic (Tonian) and
Mesoproterozoic (Stenian) peaks ca. 1.0 Ga, indicating Grenvillean- or Kibaran-age inputs that resemble the Amazonian and Mozambique Belt (Sadowski and Bettencourt 1996; Tassinari and Macambira 1999; 

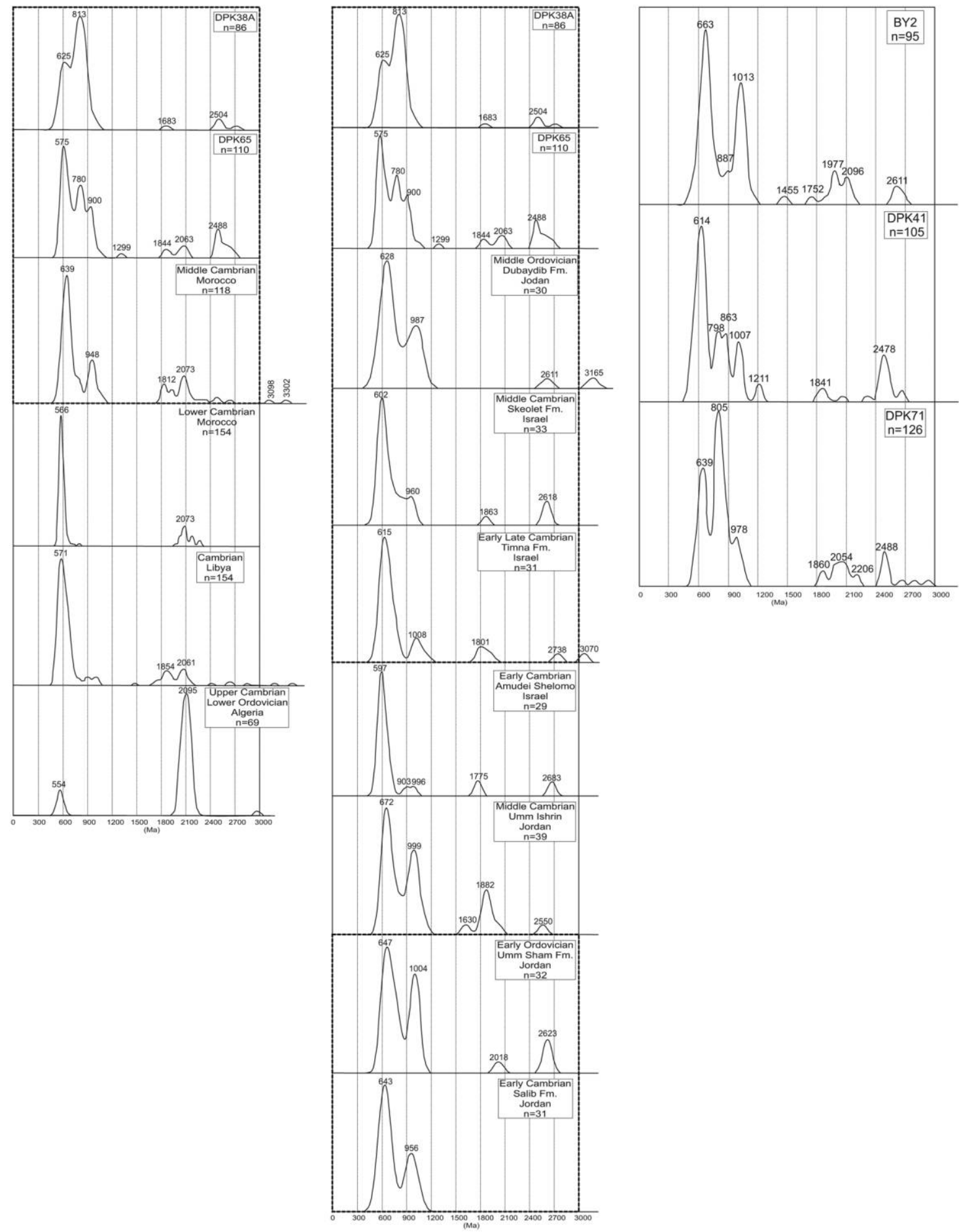

Figure 19. Kernel density plots of the detrital zircon U-Pb ages of the lonestone pebbles and diamictites and their correlations with the potential source areas in the Arabian-Nubian Shield (Israel, Jordan) and North Africa (Morocco, Algeria, Libya; Avigad et al. 2003, 2012; Kolodner et al. 2006; Linnemann et al. 2011; Altumi et al. 2013).

Santos et al. 2000; Kröner 2001). The morphologies of the Tonian detrital zircon grains are long to short prismatic, subhedral, and subrounded in DPK41 (CT) and are long prismatic and subrounded/rounded in DPK71 (ET; details in table S2; fig. S1B). This is in- consistent with long-distance transportation of the detrital zircons from either Amazonian or Mozambique Belt areas. But in BY2 (SAAB), the Tonian detrital zircon populations are generally composed of short prismatic, rounded to subrounded zircon grains 


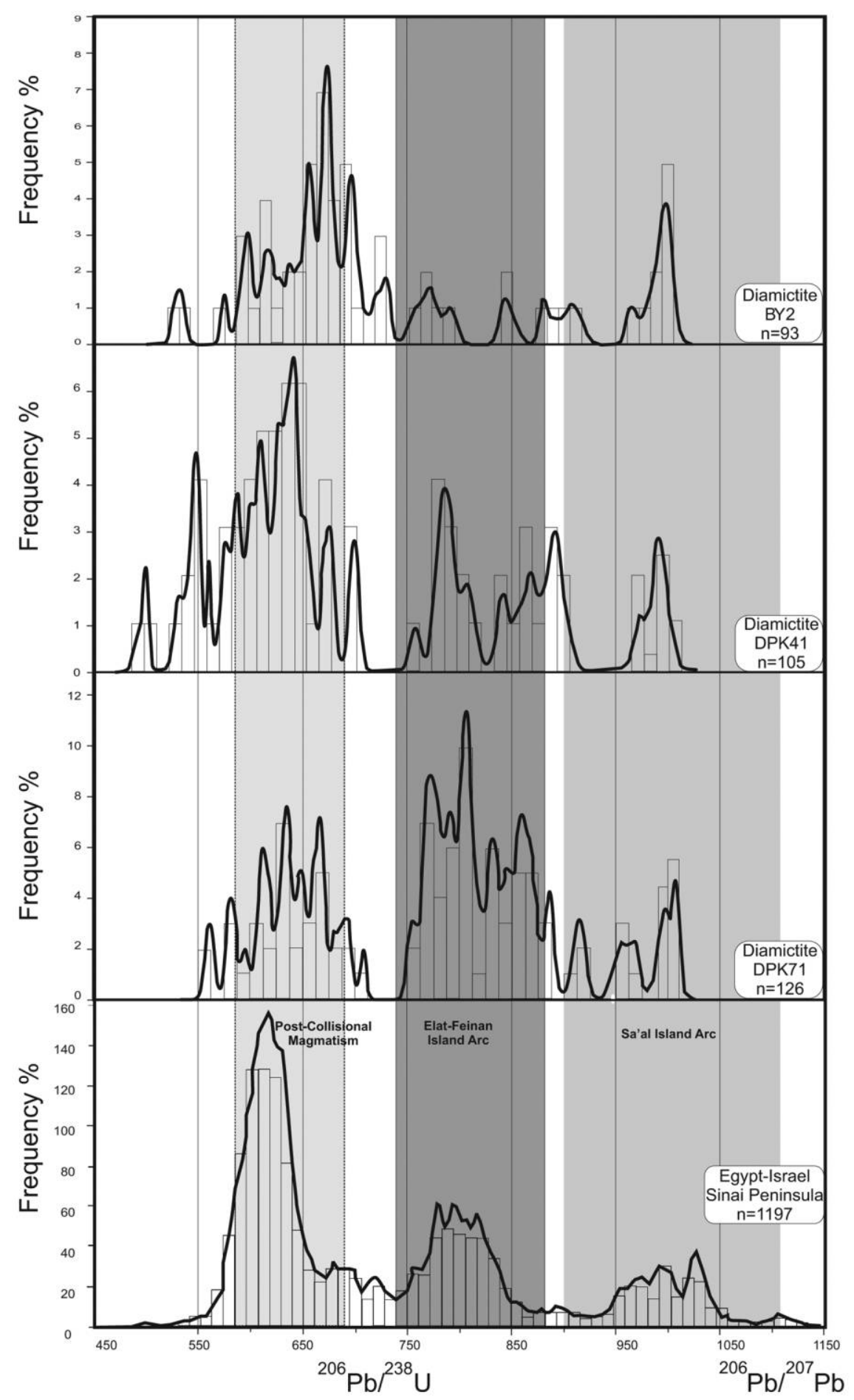

Figure 20. Probability density plots for zircon data from samples DPK41 (Eastern Taurides), DPK71 (Central Taurides), and BY2 (Southeast Anatolian Autochthon Belt) and their source correlations with igneous suites in the Sinai Peninsula (Sinai data from Be'eri Shlevin et al. 2009, 2012; Ali et al. 2009; Morag et al. 2011, 2012; Abu El-Enen and Whitehouse 2013; Eyal et al. 2014).

(table S2; fig. S1A). None of the zircon age populations in the diamictites contain grains with ages between 1.14 and $1.75 \mathrm{Ga}$ in BY2 (SAAB), between 1.22 and $1.82 \mathrm{Ga}$ in DPK41 (CT), and between 1.05 and 1.98 Ga in DPK71 (ET), and the absence of preNeoarchean zircons in the diamictites rules out their direct derivation from Amazonian and West African cratons as their potential source areas. 
The dominant peaks at $663 \mathrm{Ma}$ in BY2 (SAAB), $614 \mathrm{Ma}$ in DPK41 (ET), and $805 \mathrm{Ma}$ in DPK71 (CT) in the kernel density diagrams of the diamictites are ascribed to sources in the juvenile crust of the ANS, as defined by the studies of Shafei and Kusky (2003), Doebrich et al. (2007), Horton et al. (2008), Be'eri-Shlevin et al. (2009), Morag et al. (2011), Cox et al. (2012), Abu El-Enen and Whitehouse (2013), El-Eyal et al. (2014), and Robinson et al. (2014). However, the youngest detrital zircon ages of $499.1 \pm$ $4.2 \mathrm{Ma}(\mathrm{DPK} 41, \mathrm{ET})$ and $530.5 \pm 5.3 \mathrm{Ma}(\mathrm{BY} 2, \mathrm{SAAB})$ in the diamictites may indicate that glacio-marine successions in the ET and SAAB might have had positions closer to the Cadomian basement rocks of the ANS than the CT outcrops. The youngest age of $562.5 \pm 5.4 \mathrm{Ma}$ in the CT diamictite (DPK71) indicates that this location was close to the juvenile basement of the ANS of the Pan-African basement or was in the sediment transport path from such sources. This interpretation is in accordance with the age of the youngest igneous activity (580$570 \mathrm{Ma}$ ) in the Pan-African juvenile basement of the ANS (e.g., Fritz et al. 2010; Johnson et al. 2011). All of the samples are composed of large amounts of early Ediacaran to early Tonian detrital zircons that are also observed in the Cambro-Ordovician successions in the TAP (details in Abbo et al. 2015). Details in the Neoproterozoic zircon populations of the studied diamictite samples can also be used to investigate their provenance. The ET (DPK41) Neoproterozoic zircon population $(n=63)$ is composed of $\sim 42 \%$ Cryogenian detrital zircons with a high portion of Ediacaran and less Tonian material, whereas the CT (DPK71) Neoproterozoic zircon population $(n=93)$ contains $\sim 62 \%$ Cryogenian grains, fewer amounts of Ediacaran zircons, and about the same amount of Tonian zircons as the ET (table 1). The Neoproterozoic zircon population $(n=60)$ from SAAB sample BY2 contains 58\% Cryogenian zircons, with fewer amounts of Ediacaran and Tonian material (table 1). The relative amount of Cryogenian zircon thus increases from the ET (DPK41) to BY2 (DPK41) and the CT (DPK71; figs. 11, 20). The Neoproterozoic basement in the Sinai Peninsula is divided into four metamorphic complexes, from west to east, as the Feiran-Solaf Metamorphic Complex, the Sa'al Metamorphic Complex, the Kid Metamorphic Complex, and the Elat (Taba) Metamorphic Complex (details in Eyal et al. 2014; see fig. 17A). Significant peaks in the zircon age populations of the ET (DPK41) can be correlated with U-Pb age distributions of the postcollisional magmatic rocks in the Sinai Peninsula (660-580 Ma), the magmatic activity of the Elat (Taba)-Feiran island arc (740-870 Ma), and the Sa'al island arc (1100-900 Ma; data from Ali et al. 2009; Be'eri-Shlavin et al. 2009, 2012; Abu El-Enan and Whitehouse 2013; Eyal et al. 2014), which are interpreted as their source areas. The U-Pb detrital zircon ages in sample DPK71 (CT) display higher enrichment in the early Cryogenian to late Tonian interval, with a significant peak at $805 \mathrm{Ma}$ with early Ediacaran to late Cryogenian inputs, which might be directly derived from the magmatic activity of the Elat (Taba)-Feiran island arc (870-740 Ma) with limited contribution of postcollision magmatic suites (630-580 Ma) and the Sa'al island arc (1100900 Ma; fig. 20; Morag et al. 2012). Kernel density plots of diamictite sample BY2 from the SAAB display a different pattern, with very limited detrital zircon ages between 850 and $750 \mathrm{Ma}$ (fig. 20). The limited detrital zircon ages between 880 and $740 \mathrm{Ma}$ indicate that island arc magmatic suites in the Sinai Peninsula are not plausible areas for this sample, and the major source areas for BY2 can be fed from an area different from the Sinai Peninsula (plausible source of the Arabian Shield), although BY2 has a significant peak between 1100 and $900 \mathrm{Ma}$ (fig. 20). The western part of the Arabian Shield, including the Midyan and Hijaz terranes, displays three distinct magmatic rocks as representing arc magmatism ( 880-800 Ma), syncollisional magmatism ( 749$700 \mathrm{Ma})$, posttectonic magmatism ( 699-600 Ma), and anorogenic rift magmatism ( 599-525 Ma; Johnson 2014; Robinson et al. 2014). On the other hand, 749-650 Ma magmatic suites in eastern Arabia have been documented from $\mathrm{Ha}^{\prime} \mathrm{il}$ and Afif terranes and referred to as Nabitah orogenic phases, followed by calc-alkaline suites between $\sim 649$ and $600 \mathrm{Ma}$ and peraluminous magmatic rocks between $\sim 599$ and $550 \mathrm{Ma}$ (e.g., Doebrich et al. 2007; Cox et al. 2012; Johnson et al. 2011; Robinson et al. 2014; Johnson 2014), whereas 880-699 Ma pretectonic/posttectonic/ syntectonic magmatic rocks are observed in the Jeddah terrane of the western part of Saudi Arabia (e.g., Hargrove et al. 2006; Johnson 2014). The major significant peaks between 590 and $680 \mathrm{Ma}$ with limited Mesoproterozoic and Neoarchean detrital zircon populations in the SAAB imply provenance of the SAAB from the Ha'il/Afif terranes and Ad Dawadimi/Ar-Rayn terranes (eastern Arabian Shield) than the Jeddah terrane. Indeed, these terranes might be evaluated as the source area for the sediments of the SAAB during the depositional Late Ordovician glaciation (e.g., Hargrove et al. 2006; Doebrich et al. 2007; Cox et al. 2012; Robinson et al. 2014). The less abundant well-rounded Neoarchean detrital zircon ages with pronounced peaks of middle Paleoproterozoic ages also support the eastern Arabian proximal source for the sediments of the glacio-marine succession in the SAAB. The morphology of the early 


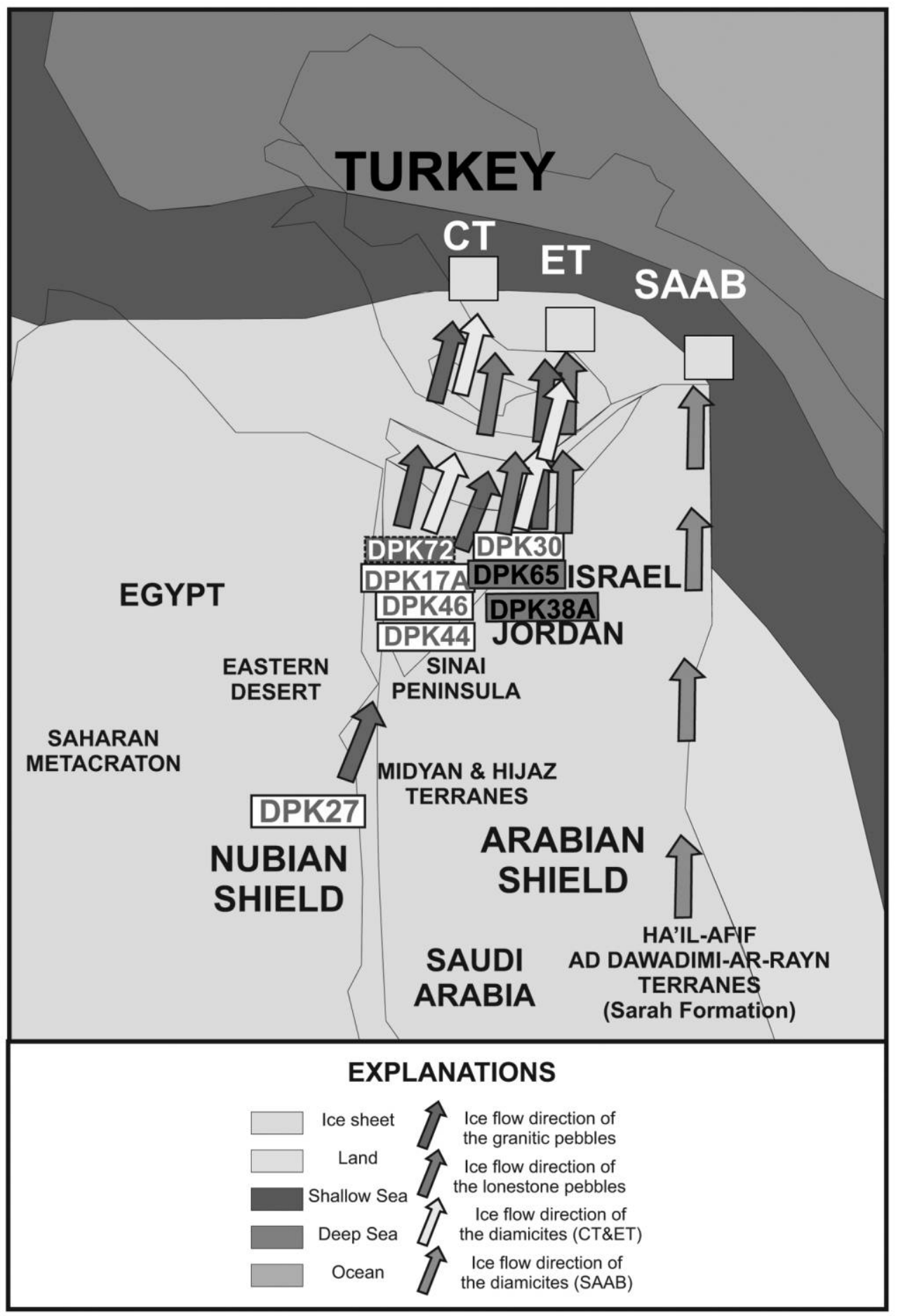

Figure 21. Schematic reconstruction of the ice flows during the Late Ordovician glaciation in the southern part of Turkey. CT $=$ Central Taurides; ET $=$ Eastern Taurides; SAAB $=$ Southeast Anatolian Autochthon Belt. A color version of this figure is available online.

Tonian/late Stenian short prismatic rounded/subrounded detrital zircon grains in the diamictite (SAAB) against equivalent successions in the $\mathrm{CT}$ and $\mathrm{ET}$ indicate that Kibaran-age detrital zircon grains might have been transported from the Mozambique Belt to the Late Ordovician sedimentary deposits by the Late Ordovician glaciation in the Arabian Shield. This scenario is also supported by the occurrence of the Late Ordovician glacio-marine successions in the northern part of Saudi Arabia (Sarah Formation in the $\mathrm{Ha}^{\prime} \mathrm{il}$ 
terrane; Clark-Lowes 2005). In addition, the proximal features of the Late Ordovician glacio-marine unit of the Sarah Formation in northern Saudi Arabia (Clark-Lowes 2005) can be correlated with the equivalent unit in the SAAB (BY2), Turkey. However, there are no published $\mathrm{U}-\mathrm{Pb}$ geochronological data from the matrices of the diamictites in this area to make a better correlation. The detrital zircon age populations imply either that the SAAB was in a different paleogeographic position than age-equivalent units in the CT and ET during the Late Ordovician or that ice flow paths to the SAAB came from a different direction.

The schematic reconstruction of the ice flows during the Late Ordovician glaciation is given in figure 21 . The granitic pebbles within the diamictite matrices were mainly derived from magmatic rocks in the Sinai Peninsula and Eastern Desert of Egypt, while the lonestone pebbles were mainly transported from Cambrian-Ordovician units in Israel and Jordan to the sediments in the CT and ET. The provenance of the detrital zircon age populations in the diamictite samples in the CT and ET indicates the Sinai Peninsula, especially the ElatFeiran island arc, the Sa'al island arc, and the postcollisional magmatic suites. The short prismatic rounded Neoarchean zircon grains within the diamictites indicate that Saharan craton zircons might have been transported to northern Africa by Neoproterozoic glaciers (e.g., Ali et al. 2010), and glacial detritus may have been reworked later into the successions by the Late Ordovician glacial ice sheets. Given the U-Pb geochronological data, the ice flow directions might have been from the northern $\mathrm{Nu}$ bian Shield (Eastern Desert to Sinai Peninsula), from Jordan and Israel northward into a shallow basin, where the CT and ET successions were formed during the end of the Hirnantian glaciation (fig. 21). Different from the deposition in the CT and ET, the corresponding glacio-marine succession in the $\mathrm{SAAB}$ have lithological and sedimentological similarities with the equivalent unit of the Late Ordovician Sarah Formation in Saudi Arabia, and the detrital material might have been mainly transported from the Ha'il/ Afif terranes northward by ice sheets during the Late Ordovician.

\section{Conclusions}

$\mathrm{U}-\mathrm{Pb}$ ages of detrital zircons from diamictites, lonestones, and magmatic zircons from granitic pebbles were investigated in detail to clarify the provenance of Late Ordovician (Hirnantian) glacio-marine sediments in the Taurides and SAAB. The following conclu- sions can be drawn from our study of the glaciomarine deposits in southern Turkey.

1. Granitic pebbles within the diamictites, especially in the outcrops of the CT and ET, have magmatic ages of $576.5 \pm 3.3,576.7 \pm 5.7,598.4 \pm 7.5$, $717.5 \pm 8.0,789.5 \pm 3.7$, and $964.6 \pm 4.6 \mathrm{Ma}$. The geochemical data indicate that the protoliths of samples DPK17A, DPK30, and DPK46 were mainly derived from arc-type sources, but the rest were derived from A-type (A2) source.

2. On the basis of the geochemical patterns and magmatic ages of the individual granitic pebbles, it is concluded that they were mainly transported from Neoproterozoic granitoids/metagranitic rocks of the Sinai Peninsula and Eastern Desert of Egypt by glaciation.

3. Early Cambrian youngest detrital zircon ages were determined in both lonestones and diamictites in the $\mathrm{CT}, \mathrm{ET}$, and $\mathrm{SAAB}$, which indicated that their positions during the Late Ordovician were close to the Cadomian basement of the peri-Gondwanan terranes. Kernel/probability density diagrams of the detrital zircon ages from the lonestones within the diamictites in the ET and CT are interpreted as evidence that they were derived from Late/Middle Cambrian siliciclastic rocks in the Israeli part of the Sinai Peninsula.

4. Abundant Late Neoproterozoic detrital zircons with high percentages of Cryogenian ages in the CT indicate that the CT may have been closer to the juvenile basement of the ANS than its counterparts in the ET and SAAB. On the basis of their detrital zircon ages, the provenance of the glacio-marine successions in the CT and ET is directly correlated with magmatic activity of the Elat-Feiran island arc, the $\mathrm{Sa}^{\prime}$ al island arc, and the postcollisional magmatic suites in the Sinai Peninsula. The coeval glacio-marine succession in the SAAB is interpreted to be derived from the Ha'il/Afif terranes of the eastern Arabian Shield during Late Ordovician glaciation.

\section{A C K N O W LED G M ENTS}

This research was financially supported by TUBITAK 2219-Turkey (International Postdoctoral Research Fellowship Program) and the Mineral Research and General Directorate (MTA/DPT project 2014-30-14.02). We thank J. Feldman (Kansas University [KU]), J. Oalmann (KU), H. Shinogle (KU), M. Sochko (KU), and $\mathrm{T}$. Tenpenny (KU) for assistance during sample preparation, laser ablation inductively coupled plasma mass spectrometry analyses, and cathodoluminescence imaging. Special thanks go to H. Güler (Diyar Mining) and H. Yusufoğlu (Mineral Research and Exploration General Directorate [MTA]) for assistance with the 
field studies and G. Demiray (MTA) and G. Topuz (Istanbul Technical University) for sample prepara- tion. T. Abu-Alam helped to improve a previous version of this article.

\section{REFEREN CES CITED}

Abed, M. A.; Makhlouf, I. M.; Amireh, B. S.; and Khalil, B. 1993. Upper Ordovician glacial deposits in southern Jordan. Episodes 16:316-328.

Abbo, A.; Avigad, D.; Gerdes, A.; and Güngör, T. 2015. Cadomian basement and Paleozoic to Triassic siliciclastics of the Taurides (Karacahisar dome, south-central Turkey): paleogeographic constraints from U-Pb-Hf in zircons. Lithos 227:122-139.

Abdelsalam, M. G.; Liegeois, J. P.; and Stern, R. J. 2002. The Saharan metacraton. I. Afr. Earth Sci. 34:119-136.

Abu El-Enen, M. M.; Abu-Alam, S. T.; Whitehouse, M. J.; Kamal, A. A.; and Okrusch, M. 2016. P-T path and timing of crustal thickening during amalgamation of East and West Gondwana: a case study from the Hafafit Metamorphic Complex, Eastern Desert of Egypt. Lithos 263:213-238.

Abu El-Enen, M. M., and Whitehouse, M. J. 2013. The Feiran-Solaf Metamorphic Complex, Sinai, Egypt: geochronological and geochemical constraints on its evolution. Precambrian Res. 239:106-125.

Ali, A. K.; Kröner, A.; Hegner, E.; Wong, J.; Shang-Qing, L.; Gahlan, H. A.; Fawzy, F.; and Ela, A. E. 2015. U-Pb zircon geochronology and Hf-Nd isotopic systematics of Wadi Beitan granitoid gneisses, South Eastern Desert, Egypt. Gondwana Res. 27:811-824.

Ali, A. K.; Stern, R. J.; Manton, I. W.; Johnson, P. R.; and Mukherjee, K. S. 2010. Neoproterozoic diamictite in the Eastern Desert of Egypt and northern Saudi Arabia: evidence of $\sim 750 \mathrm{Ma}$ glaciation in the Arabian-Nubian Shield? Int. I. Earth Sci. 99:705-726.

Ali, A. K.; Zoheir, B.; Stern, J. R.; Anderesen, A.; Whitehouse, M. J.; and Bishara, W. W. 2016. Lu-Hf and $\mathrm{O}$ isotopic compositions on single zircons from the North Eastern Desert of Egypt, Arabian Nubian Shield: implications for crustal evolution. Gondwana Res. 32: 181-192.

Ali, B. H.; Wilde, S. A.; and Gabr, M. M. A. 2009. Granitoid evolution in Sinai, Egypt, based on precise SHRIMP U-Pb zircon geochronology. Gondwana Res. 15:38-48.

Altumi, M. M.; Elicki, O.; Linnemann, U.; Hofmann, M.; Sagawe, A.; and Gärtner, A. 2013. U-Pb LA-ICP-MS detrital zircon ages from the Cambrian of $\mathrm{Al}$ Qarqaf arch, central-western Libya: provenance of the West Gondwanan sand sea at the dawn of the early Palaeozoic. I. Afr. Earth Sci. 79:74-97.

Astini, R. A. 2003. The Ordovician proto-Andean basins. In Benedetto, J. L., ed. Ordovician fossils of Argentina. Córdoba, Universidad Nacional de Córdoba, p. 1-74.

Avigad, D.; Abbo, A.; and Gerdes, A. 2016. Origin of the eastern Mediterranean: Neotethys rifting along a cryptic Cadomian suture with Afro-Arabia. Geol. Soc. Am. Bull. 128:1286-1296.
Avigad, D.; Kolodner, K.; McWilliams, M.; Persing, H., and Weissbrod, T. 2003. Origin of northern Gondwana Cambrian sandstone revealed by detrital zircon SHRIMP dating. Geology 31:227-230.

Avigad, D.; Gerdes, A.; Morag, N.; and Bechstädt, T. 2012. Coupled U-Pb-Hf of detrital zircons of Cambrian sandstones from Morocco and Sardinia: implications for provenance and Precambrian crustal evolution of North Africa. Gondwana Res. 21:690-703.

Avigad, D.; Sandler, A.; Kolodner, K.; Stern, R. J.; McWilliams, M.; Miller, N.; and Beyth, M. 2005. Massproduction of Cambro-Ordovician quartz-rich sandstone as a consequence of chemical weathering of Pan-African terranes: environmental implications. Earth Planet. Sci. Lett. 240:818-826.

Be'eri-Shlevin, Y.; Eyal, M.; Eyal, Y.; Whitehouse, M. J.; and Litvinovsky, B. 2012. The Sa'al volcano-sedimentary complex (Sinai, Egypt): a latest Mesoproterozoic volcanic arc in the northern Arabian Nubian Shield. Geology 40:403-406.

Be'eri-Shlevin, Y.; Katzir, Y.; and Whitehouse, M. 2009. Post-collisional tectonomagmatic evolution in the northern Arabian-Nubian Shield: time constraints from ionprobe U-Pb dating of zircon. I. Geol. Soc. Lond. 166:71-85.

Beuf, S.; Biju-Duval, B.; De Charpal, O.; Rognon, P.; Gariel, O.; and Bennacef, A. 1971. Les grés du Paléozoique inférieur au Sahara. Paris, Institut Français du Pétrolé Technip.

Biju-Duval, B.; Deynoux, M.; and Rognon, P. 1981. Late Ordovician tillites of the central Sahara. In Hambrey, M. J., and Harland, W. B., eds. Earth's pre-Pleistocene glacial record. Cambridge, Cambridge University Press, p. 99-107.

Bozdoğan, N.; Göncüoğlu, M. C.; and Kozlu, H. 1996. Lower Paleozoic stratigraphy of SE Anatolia. In Baldis, B. A., and Acenolaza, F. G., eds. El Paleozoico inferior en el noroeste del Gondwana (The lower Paleozoic of NW Gondwana). Serie Correlacion Geologica. Instituto Superior Correlación Geológica, Universidad Nacional de Tucumán, Tucumán, 12:47-58.

Caputo, M. V. 1998. Ordovician-Silurian glaciations and global sea-level changes. Bull. N. Y. State Mus. 491: $15-25$.

Cater, J. M. L., and Tunbridge, I. P. 1992. Palaeozoic tectonic history of SE Turkey. I. Petrol. Geol. 15:35-50.

Clark-Lowes, D. D. 2005. Arabian glacial deposits: recognition of palaeovalleys within the Upper Ordovician Sarah Formation, Al Qasim district, Saudi Arabia. Proc. Geol. Assoc. 116:331-347.

Cole, J. C., and Hedge, C. E. 1986. Geochronologic investigation of Late Proterozoic rocks in the northeastern Shield of Saudi Arabia. Saudi Arabian Deputy Ministry 
for Mineral Resources Technical Record USGS-TR-05-5, $42 \mathrm{p}$.

Cooper, J. A.; Stacey, J. S.; Stoeser, D. B.; and Fleck, R. J. 1979. An evaluation of the zircon method of isotopic dating in the southern Arabian craton. Contrib. Mineral. Petrol. 68:429-439.

Cox, G. M.; Lewis, J. C.; Collins, A. S.; Halverson, G. P.; Jourdan, F.; Foden, J.; Nettle, D.; and Kattan, F. 2012. Ediacaran terrane accretion within the Arabian-Nubian Shield. Gondwana Res. 21:341-352.

Dean, W. T.; Monod, O.; and Perincek, D. 1981. Correlations of Cambrian and Ordovician rocks in southeastern Turkey. T. C. Petrol Işleri Genel Müdürlüğü Dergisi 25:269-291.

Demirtaşl1, E. 1984. Stratigraphy and tectonics of the area between Silifke and Anamur, central Taurus Mountain. In Tekeli, O., and Göncüoğlu, M. C., eds. Geology of the Taurus Belt. Ankara, Mineral Research and Exploration Institute of Turkey (MTA) Publications, p. 101-118.

Denis, M.; Buoncristiani, J. F.; Konate, M.; Yahaya, M.; and Guiraud, M. 2006. Typology of Hirnantian glacial pavements in SW Diado Basin (NE Niger). Afr. Geosci. Rev. 13:145-155.

Destombes, J.; Hollard, H.; and Willefert, S. 1985. Lower Palaeozoic rocks of Morocco. In Holland, C. H., ed. Lower Paleozoic rocks of northwest and west-central Africa. New York, Wiley, p. 91-336.

Deynoux, M.; Sougy, J.; and Trompette, R. 1985. Lower Paleozoic rocks of West Africa and the western part of Central Africa. In Holland, C. H., ed. Lower Paleozoic rocks of northwest and west-central Africa. New York, Wiley, p. 337-495.

Doebrich, J. L.; Al-Jehani, A. M.; Siddiqui, A. A.; Hayes, T. S.; Wooden, J. L.; and Johnson, P. R. 2007. Geology and metallogeny of the Ar Rayn terrane, eastern Arabian Shield: evolution of a Neoproterozoic continentalmargin arc during assembly of Gondwana within the East African orogeny. Precambrian Res. 158:17-50.

Duyverman, H. J.; Harris, N. B. W.; and Hawkesworth, C. J. 1982. Crustal accretion in the Pan-African: $\mathrm{Nd}$ and $\mathrm{Sr}$ isotope evidence from the Arabian Shield. Earth Planet. Sci. Lett. 59:315-326.

Eby, G. N. 1992. Chemical subdivision of the A-type granitoids: petrogenetic and tectonic implications. Geology 20:641-644.

El-Sayed, M. M.; Fumes, H.; and Abou Shagar, S. 2007. Growth of the Egyptian crust in the northern East African orogen: a review of existing models and proposed modifications. N. Jb. Miner. Abh. 183:317-341.

El-Shafei, M. K., and Kusky, T. M. 2003. Structural and tectonic evolution of the Neoproterozoic Feiran-Solaf metamorphic belt, Sinai Peninsula: implications for the closure of the Mozambique Ocean. Precambrian Res. 123:269-293.

Eyal, M.; Be'eri-Shlevin, Y.; Eyal, Y.; Whitehouse, M. J.; and Litvinovsky, B. 2014. Three successive Proterozoic island arcs in the Northern Arabian-Nubian Shield: evidence from SIMS U-Pb dating of zircon. Gondwana Res. 25:338-357.
Fortuin, A. R. 1984. Late Ordovician glaciomarine deposits (Orea shale) in the Sierra de Albarracin, Spain. Palaeogeogr. Palaeoclimatol. Palaeoecol. 48:245-261.

Fritz, H.; Abdelsalam, M.; Ali, K. A.; Bingen, B.; Collins, A. S.; Fowler, A. R.; Ghebreab, W.; et al. 2010. Orogen style in the East African orogen: a review of the Neoproterozoic to Cambrian tectonic evolution. I. Afr. Earth Sci. 86:65-106.

Ghavidel-syooki, M.; Álvero, J. J.; Popov, L.; Pour, M. G.; Ehsani, M. H.; and Suyarkova, A. 2011. Stratigraphic evidence for the Hirnantian (latest Ordovician) glaciation in the Zagros Mountains, Iran. Palaeogeogr. Palaeoclimatol. Palaeoecol. 307:1-16.

Ghienne, J. F. 2003. Late Ordovician sedimentary environments, glacial cycles, and post-glacial transgression in the Taoudeni Basin, West Africa. Palaeogeogr. Palaeoclimatol. Palaeoecol. 189:117-145.

Ghienne, J. F., and Deynoux, M. 1998. Large-scale channel fill structures in Late Ordovician glacial deposits in Mauritania, western Sahara. Sediment. Geol. 119:141159.

Ghienne, J. F.; Deynoux, M.; Manatschal, G.; and Rubino, J. L. 2003. Palaeovalleys and fault-controlled depocentres in the Late-Ordovician glacial record of the Murzuq Basin (central Libya). C. R. Geosci. 335:1091-1100.

Ghienne, J. F.; Le Heron, D. P.; Moreau, J.; Denis, M.; and Deynoux, M. 2007. The Late Ordovician glacial sedimentary system of the North Gondwana platform. In Hambrey, M. J.; Christoffersen, P.; Glasser, N. F.; and Hubbard, B., eds. Glacial sedimentary processes and products. International Association of Sedimentologists Special Publications 39. Oxford, Blackwell, p. 295-314.

Ghienne, J. F.; Monod, O.; Kozlu, H.; and Dean, W. T. 2010. Cambrian-Ordovician depositional sequences in the Middle East: a perspective from Turkey. Earth Sci. Rev. 1010:101-146.

Göncüoğlu, M. C. 1997. Distribution of Lower Paleozoic units in the Alpine terranes of Turkey: paleogeographic constraints. In Göncüoğlu, M. C., and Derman, A. S., eds. Lower Paleozoic evolution in northwest Gondwana. Turkish Assoc. Petrol. Geol. Spec. Publ. 3:13-24.

2010. Introduction to the geology of Turkey: geodynamic evolution of the pre-alpine and alpine terranes. Ankara, MTA Monography Series, 66 p.

Göncüoglu, M. C.; Göncüoglu, Y.; Kozlu, H.; and Kozur, H. 2004. Paleozoic stratigraphy of the Geyikdag Unit in the Eastern Taurides (Turkey): new age data and implications for Gondwanan evolution. Geol. Carphatica 55:433-447.

Göncüoğlu, M. C., and Kozlu, H. 2000. Early Paleozoic evolution of the NW Gondwanaland: data from southern Turkey and surrounding regions. Gondwana Res. 3:315324.

Gornitz, V. 2009. Encyclopedia of paleoclimatology and ancient environments. Amsterdam, Springer, 1047 p.

Gürsu, S. 2016. A new petrogenetic model for metagranitic rocks in the central and southern Menderes Massif-W Turkey: implications for Cadomian crustal 
evolution within the Pan-African mega-cycle. Precambrian Res. 275:450-470.

Gürsu, S.; Möller, A.; Göncüoğlu, M. C.; Köksal, S.; Demircan, H.; Köksal, F. T.; Kozlu, H.; and Sunal, G. 2015. Neoproterozoic continental arc volcanism at the northern edge of the Arabian plate, SE Turkey. Precambrian Res. 258:208-233.

Gutiérrez-Marco, J. C.; Ghienne, J. F.; Bernardez, E.; and Hacar, M. P. 2010. Did the Late Ordovician African ice sheet reach Europe? Geology 38:279-282.

Guynn, J., and Gehrels, G. 2010. Comparison of detrital zircon age distributions using the KS test. University of Arizona online data set, www.geo.arizona.edu/alc.

Hargrove, U. S.; Stern, R. J.; Kimura, J. I.; Manton, W. I.; and Johnson, P. R. 2006. How juvenile is the ArabianNubian Shield? evidence from $\mathrm{Nd}$ isotopes and preNeoproterozoic inherited zircon in the Bi'r Umq suture zone, Saudi Arabia. Earth Planet. Sci. Lett. 252: 308-326.

Hassan, M.; Stüwe, K.; Abu-Alam, T. S.; Klötzli, U.; and Tiepolo, M. 2016. Time constraints on deformation of the Ajjaj branch of one of the largest Proterozoic shear zones on Earth: the Najd fault system. Gondwana Res. 34:346-362.

Hiller, N. 1992. The Ordovician system in South Africa: a review. In Webby, L., ed. Global perspectives on Ordovician geology. Rotterdam, Balkema, p. 473-485.

Horton, B. K.; Hassanzadeh, J.; Stockli, D. F.; Axen, G. J.; Gillis, R. J.; Guest, B.; Amini, A.; Fakhari, M. D.; Zamanzadeh, S. M.; and Grove, M. 2008. Detrital zircon provenance of Neoproterozoic to Cenozoic deposits in Iran: implications for chronostratigraphy and collisional tectonics. Tectonophysics 451:97-122.

Jackson, S. E.; Pearson, N. J.; Griffin, W. L.; and Belousova, E. A. 2004. The application of laser ablationinductively coupled plasma-mass spectrometry to in situ U-Pb zircon geochronology. Chem. Geol. 211:4769.

Johnson, P. R. 2014. An expanding Arabian-Nubian Shield geochronologic and isotopic dataset: defining limits and confirming the tectonic setting of a Neoproterozoic accretionary orogeny. Open Geol. I. 8(suppl. 1):3-33.

Johnson, P. R.; Andresen, A.; Collins, A. S.; Fowler, A. R.; Fritz, H.; Ghebreab, W.; Kusky, T.; and Stern, R. J. 2011. Late Cryogenian-Ediacaran history of the Arabian-Nubian Shield: a review of depositional, plutonic, structural and tectonic events in the closing stages of the northern East African orogen. I. Afr. Earth Sci. 61:167-232.

Johnson, P. R.; Kattan, F. H.; and Wooden, J. L. 2001. Implications of SHRIMP and microstructural data on the age and kinematics of shearing in the Asir terrane, southern Arabian Shield, Saudi Arabia. Gondwana Res. 4:172-173.

Katzir, Y.; Eyal, M.; Litvinovsky, B. A.; Jahn, B. M.; Zanvilevich, A. N.; Valley, J. W.; Beeri, Y.; Pelly, I.; and Shimshilashvili, E. 2007. Petrogenesis of A-type granites and origin of vertical zoning in the Katharina pluton, Gebel Mussa (Mt. Moses) area, Sinai, Egypt. Lithos 95:208-228.

Kennedy, A.; Kozdroj, W.; Johnson, P. R.; and Kattan, F. H. 2011. SHRIMP geochronology in the northern Arabian Shield. III. Data acquisition 2006. Saudi Geological Survey Open-File Report SGS-OF-2007-9.

Kolodner, K. 2007. The provenance of the siliciclastic section in Israel and Jordan: U-Pb dating of detrital zircon. PhD thesis, Hebrew University of Jerusalem.

Kolodner, K.; Avigad, D.; McWilliams, M.; Wooden, J. L.; Weissbrod, T.; and Feinstein, S. 2006. Provenance of north Gondwana Cambrian-Ordovician sandstone: U-Pb SHRIMP dating of detrital zircons from Israel and Jordan. Geol. Mag. 143:367-391.

Kozlu, H., and Ghienne, J. F. 2012. Ordovician. Paleozoic of northern Gondwana and its petroleum potential a field workshop. In Göncüoğlu, M. C., and Bozdoğan, N., eds. Guidebook Paleozoic of Eastern Taurides. Turk. Assoc. Petrol. Geol. Spec. Publ. 7:42-60.

Kozlu, H.; Göncüoğlu, M. C.; Sarmiento, G.; and Gül, M. A. 2002. Mid-Ordovician (Late Darriwilian) conodonts from the Southern-Central Taurides, Turkey: geological implications. Turk. J. Earth Sci. 11:113-126.

Kröner, A. 2001. The Mozambique Belt of East Africa and Madagascar: significance of zircon and $\mathrm{Nd}$ model ages for Rodinia and Gondwana supercontinent formation and dispersal. S. Afr. I. Geol. 104:151-166.

Kröner, A.; Eyal, M.; and Eyal, Y. 1990. Early Pan-African evolution of the basement around Elat, Israel and the Sinai Peninsula revealed by single zircon evaporation dating and implications for crustal accretion rates. Geology 18:545-548.

Le Heron, D. P. 2007. Late Ordovician glacial record of the Anti-Atlas, Morocco. Sediment. Geol. 201:93-110.

Le Heron, D. P.; Armstrong, H. A.; Wilson, C.; Howard, J. P.; and Gindre, K. 2010. Glaciation and deglaciation of the Libyan desert: the Late Ordovician record. Sediment. Geol. 223:100-125.

Le Heron, D. P., and Craig, J. 2008. First-order reconstruction of a Late Ordovician Saharan ice sheet. I. Geol. Soc. Lond. 165:19-29.

Linnemann, U.; Ouzegane, K.; Drareni, A.; Hofmann, M.; Becker, S.; Gärtner, A.; and Sagawe, A. 2011. Sands of West Gondwana: an archive of secular magmatism and plate interactions - a case study from the CambroOrdovician section of the Tassili Quan Ahaggar (Algerian Sahara) using U-Pb-LA-ICP-MS detrital zircon ages. Lithos 123:188-203.

Ludwig, K. R. 2003. User's manual for Isoplot 3.00: a geochronological toolkit for Microsoft Excel. Berkeley Geochronology Center Special Publication 4, 70 p.

Martin, J. R.; Redfern, J.; and Aitken, J. F. 2008. A regional overview of the Late Paleozoic glaciation in Oman. In Fielding, C. R.; Frank, T. D.; and Isbell, J. C., eds. Resolving the Late Paleozoic ice age: time and space. Geol. Soc. Am. Spec. Pap. 441:175-186.

Martinez, M. 1998. Late Ordovician glacial deposits of northwest Argentina: new evidence from the Mecoyita 
Formation, Santa Victoria Range. J. Afr. Earth Sci. 27: 136-137.

Massa, D. 1988. Paléozoîque de Libye occidentale. Stratigraphie et paléogeographié thesis, University of Nice.

McGillivray, G. J., and Husseini, M. 1992. The Paleozoic petroleum geology of Central Saudi Arabia. Am. Assoc. Pet. Geol. Bull. 76:1473-1490.

Meert, J. G., and Liebermann, B. S. 2008. The Neoproterozoic assembly of Gondwana and its relationship to the Ediacaran-Cambrian radiation. Gondwana Res. 14:5-21.

Meinhold, G.; Morton, A. C.; Fanning, C. M.; Frei, D.; Howard, J. P.; Philips, R. J.; Strogen, D.; and Whitham, A. G. 2011. Evidence from detrital zircons for recycling of Mesoproterozoic and Neoproterozoic crust recorded in Paleozoic and Mesozoic sandstones of southern Libya. Palaeogeogr. Palaeoclimatol. Palaeoecol. 51: 273-289.

Meyer, E. S.; Passchier, C.; Abu-Alam, T.; and Stüwe, K. 2014. A strike-slip core complex from the Najd fault system, Arabian Shield. Terra Nova 26:387-394.

Moghazi, A. M.; Iaccheri, L. M.; Bakhsh, R. A.; Kotov, A. B.; and Ali, K. A. 2015. Sources of rare-metal-bearing A-type granites from Jabel Sayed complex, northern Arabian Shield, Saudi Arabia. Iournal of Asian Earth Sciences 107:244-258.

Monod, O.; Kozlu, H.; Ghienne, J. F.; Dean, W. T.; Günay, Y.; Le Hérissé, A.; Paris, F.; and Robardet, M. 2003. Late Ordovician glaciation in southern Turkey. Terra Nova 15:249-257.

Morag, N.; Avigad, D.; Gerdes, A.; Belousova, E.; and Harlavan, Y. 2011. Crustal evolution and recycling in the northern Arabian-Nubian Shield: new perspectives from zircon Lu-Hf and U-Pb systematics. Precambrian Res. 186:101-116.

Morag, N.; Avigad, D.; Gerdes, A.; and Harlavan, Y. 2012. 1000-580 Ma crustal evolution in the northern ArabianNubian Shield revealed by U-Pb-Hf of detrital zircons from Late Neoproterozoic sediments (Elat area, Israel). Earth Planet. Sci. Lett. 312:164-175.

Moreno, J. A.; Molina, J. F.; Montero, P.; Abu Anbar, M.; Scarrow, J. H.; Cambesesi, A.; and Bea, F. 2014. Unraveling sources of A-type magmas in juvenile continental crust: constraints from compositionally diverse Ediacaran post-collisional granitoids in the Katerina Ring Complex, southern Sinai, Egypt. Lithos 192-195: 56-85.

Moreno, J. A.; Montero, P.; Abu Anbar, M.; Molina, J. F.; Scarrow, J. H.; Talavera, C.; Cambeses, A., and Bea, F. 2012. SHRIMP U-Pb zircon dating of the Katerina Ring Complex: insights into the temporal sequence of Ediacaran calc-alkaline to peralkaline magmatism in southern Sinai, Egypt. Gondwana Res. 21:887-900.

Moussa, E. M. M.; Stern, R. J.; Manton, W. I.; and Ali, K. A. 2008. SHRIMP zircon dating and $\mathrm{Sm} / \mathrm{Nd}$ isotopic investigations of Neoproterozoic granitoids, Eastern Desert, Egypt. Precambrian Res. 160:341-356.

Özgül, N., and Kozlu, H. 2002. Data on the stratigraphy and tectonics of the Kozan-Fekeregion (Eastern Tau rides). Turk. Assoc. Petrol. Geol. Bull. 14:1-36 (in Turkish with English abstract).

Özgül, N.; Metin, S.; Göğer, İ.; Bingöl, İ.; Baydar, O.; and Erdoğan, B. 1973. Cambrian-Tertiary rocks of the Tufanbeyli region, Eastern Taurus, Turkey. Geol. Bull. Turk. 16:81-101 (in Turkish with English abstract).

Paris, F.; Le Hérissé, A.; Monod, O.; Kozlu, H.; Ghienne, J. F.; Dean, W. T.; Vecoli, M.; and Günay, Y. 2007. Ordovician chitinozoans and acritarchs from southern and southeastern Turkey. Rev. Micropaleontol. 50: 81-107.

Paris, F.; Verniers, J.; and Al-Hajri, S. 2000. Ordovician chitinozoans from central Saudi Arabia. In Al-Hajri, A., and Owens, B., eds. Stratigraphic palynology of the Palaeozoic of Saudi Arabia. GeoArabia Spec. Publ. 1: 42-56.

Paton, C.; Hellstrom, J.; Paul, B.; Woodhead, J.; and Hergt, J. 2011. Iolite: freeware for the visualization and processing of mass spectrometric data. I. Anal. Atom. Spectrosc. 26:2508-2518.

Pearce, J. A. 1983. Role of the sub-continental lithosphere in magma genesis at active continental margins. In Hawkesworth, C. J., and Norry, M. J., eds. Continental basalts and mantle xenoliths. Nantwich, Cheshire, Shiva Publications, p. 230-249.

Pearce, J. A.; Harris, N. B. W.; and Tindle, A. G. 1984. Trace element discrimination diagrams for the tectonic interpretation of granitic rocks. I. Petrol. 25:956983.

Petrus, J. A., and Kamber, B. S. 2012. VizualAge: a novel approach to laser ablation ICP-MS U-Pb geochronology data reduction. Geostand. Geoanal. Res. 36:247-270.

Robardet, M., and Dore, F. 1988. The Late Ordovician diamictic formations from southwestern Europe: NorthGondwanaland glaciomarine deposits. Palaeogeogr. Palaeoclimatol. Palaeoecol. 66:19-31.

Robinson, F. A.; Foden, J. D.; Collins, A. S.; and Payne, J. L. 2014. Arabian Shield magmatic cycles and their relationship with Gondwana assembly: insights from zircon $\mathrm{U}-\mathrm{Pb}$ and $\mathrm{Hf}$ isotopes. Earth Planet. Sci. Lett. 408:207-225.

Rösel, D.; Boger, S. D.; Möller, A.; Gaitzsch, B.; Barth, M.; Oalmann, J.; and Zack, T. 2014. Indo-Antarctic derived detritus on the northern margin of Gondwana: evidence for continental-scale sediment transport. Terra Nova 26:64-71.

Sadowski, G. R., and Bettencourt, J. S. 1996. Mesoproterozoic tectonic correlations between eastern Laurentia and the western border of the Amazon craton. Precambrian Res. 76:213-227.

Santos, J. O. S.; Hartmann, L. A.; Gaudette, H. E.; Groves, D. I.; McNaughton, N. J.; and Fletcher, I. R. 2000. A new understanding of the provinces of the Amazon Craton based on integration of field mapping and $\mathrm{U}-\mathrm{Pb}$ and Sm-Nd geochronology. Gondwana Res. 3:453-488.

Sláma, J.; Košler, J.; Condon, D. J.; Crowley, J. I.; Gerdes, A.; Hanchar, J. M.; Horstwood, M. S. A.; et al. 2008. Plešovice zircon: a new natural reference material for 
$\mathrm{U}-\mathrm{Pb}$ and $\mathrm{Hf}$ isotopic microanalysis. Chem. Geol. 249: 1-35.

Storch, P. 2006. Facies development, depositional settings and sequence stratigraphy across the OrdovicianSilurian boundary: a new perspective from the Barrandian area of the Czech Republic. Geol. I. 41:163-192.

Sultan, M.; Chamberlain, K. R.; Bowring, S. A.; Arvidson, R. E.; Abuzied, H.; and El Kaliouby, B. 1990. Geochronological and isotopic evidence for the involvement of pre-Pan African crust in the Nubian Shield, Egypt. Geology 18:761-764.

Sun, S. S., and McDonough, W. F. 1989. Chemical and isotopic systematics of oceanic basalts: implications for mantle composition and process. In Saunders, A. D., and Norry, M. J. eds. Magmatism in ocean basins. Geol. Soc. Spec. Publ. 42:313-345.

Tassinari, C. C. G., and Macambira, M. J. B. 1999. Geochronological provinces of the Amazon Craton. Episodes 22:174-182.

Taylor, S. R., and McLennan, S. M. 1995. The geochemical evolution of the continental crust. Rev. Geophys. 33:241-265.

Tera, F., and Wasserburg, G. J. 1972. U-Th-Pb systematics in three Apollo 14 basalts and the problem of initial $\mathrm{Pb}$ in lunar rocks. Earth Planet. Sci. Lett. 14:281-304.
Torsvik, H. T., and Cocks, L. R. M. 2011. The Palaeozoic palaeogeography of central Gondwana. In Van Hinsbergen, D. J. J.; Butter, S. J. H.; Torsvik, T. H.; Gaina, C.; and Webb, S. J., eds. The formation and evolution of Africa: a synopsis of $3.8 \mathrm{Ga}$ of earth history. Geol. Soc. Spec. Publ. 357:137-166.

Tucker, M. E., and Reid, P. C. 1973. The sedimentology and context of Late Ordovician glacial marine sediments from Sierra Leone, West Africa. Palaeogeogr. Palaeoclimatol. Palaeoecol. 13:289-307.

Turner, B. R.; Makhlouf, I. M.; and Armstrong, H. A. 2005. Late Ordovician (Ashgillian) glacial deposits in southern Jordan. Sediment. Geol. 181:73-91.

Vaslet, D. 1990. Upper Ordovician glacial deposits in Saudi Arabia. Episodes 13:147-161.

Vermeesch, P. 2012. On the visualization of detrital age distributions. Chem. Geol. 312-313:190-194.

von Raumer, J. F., and Stampfli, G. M. 2008. The birth of the Rheic Ocean: Early Palaeozoic subsidence patterns and subsequent tectonic plate scenarios. Tectonophysics 461:9-20.

Wetherill, G. W. 1956. Discordant uranium-lead ages. Trans. Am. Geophys. Union 37:320-326.

Willefert, S. 1988. The Ordovician-Silurian boundary in Mauritania. Bull. Br. Mus. (Nat. Hist.) Geol. 43:177-182. 